University of Rhode Island

DigitalCommons@URI

Open Access Master's Theses

1982

\title{
A Case Study on the Development of Social Indicators Model: The Assessment of the Effects of Italy's Membership in the EEC on the Quality of Life
}

Lia T. Vasconcelos

University of Rhode Island

Follow this and additional works at: https://digitalcommons.uri.edu/theses

\section{Recommended Citation}

Vasconcelos, Lia T., "A Case Study on the Development of Social Indicators Model: The Assessment of the Effects of Italy's Membership in the EEC on the Quality of Life" (1982). Open Access Master's Theses.

Paper 394.

https://digitalcommons.uri.edu/theses/394

This Thesis is brought to you for free and open access by DigitalCommons@URI. It has been accepted for inclusion in Open Access Master's Theses by an authorized administrator of DigitalCommons@URI. For more information, please contact digitalcommons-group@uri.edu. 


\section{A CASE STUDY ON THE DEVELOPMENT}

OF

SOCIAL INDICATORS MODEL:

The assessment of the effects of Italy's membership

in the EEC on the quality of life.

A RESEARCH PROJECT SUBMITTED IN

PARTIAL FULFILLMENT OF. THE REQUIREMENTS

FOR THE DEGREE OF MASTER OF

COMMUNITY PLANNING

UNIVERSITY OF RHODE ISLAND

1982 


\section{MASTER OF COMMUNITY PLANNING RESEARCH PROJECT \\ OF}

LIA T. VASCONCELOS

Approved:

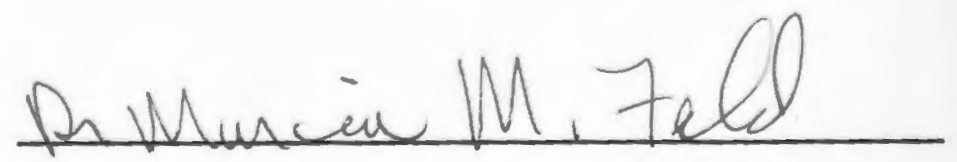

Major Professor

Marcia M. Feld

Director

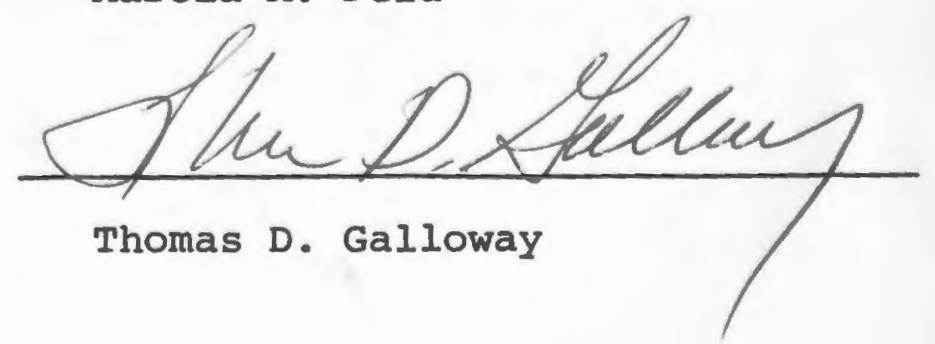


VIIA

Lia Maldcnado Teles de Vasconcelos was torn on the 20 th of June of 1953 in Maputo. Mozambique. She was ararded in 1977 the diploma in Architecture ('Iicenciatura') by the Escola superior de Belas Artes, oniversidade Tecrica de Iisboa, Portugal. Between 1973 and 1977 she worked in the offices of several architects as an architect practiticner. Upon completion of her Architect studies, the author participated in a researct project on Data Bases for Urban Analysis and Town Planning at the Laboratorio Nacional de Engenharia Civil, Iisboa, Portugal. She joinned the Graduate curriculum in Commity Planning and Area Development oi the oniversity of Rhode Island in 1979. Since then she has participated in several planning frojects under the direction of Dr. Marcia M. Feld. 
ACRNOHLE LGEUENTS

The author would like to thank professor Marcia M. Feld for her excellent advice, encouragement and patience during the development of this work. Her permanent professional enthusiasm and the atmosphere of friendship she maintains with her collaborators has been a most rewarding experience.

Professor Howard Fostex reading of the manuscript and his criticism were greatly appreciated.

Thanks are also due to the autbor's colleagua Joanne Cassulo for ber readiness to discuss and belp with the editing of the manuscript. 
CONTENTS

VITA $\quad$ I

ACKNCWLEDGENENTS

\section{Chaㅡ트르}

pagge

I. INT GODUCTION .................... 1

Issue Statement . . . . . . . . . . . . . . . . 1

Metiodology ....................... 1

Significance of the application chosen..... . . . . 3

organization of the text................ 4

II. GENERAI BACKGROUND ON THE EEC . . . . . . . . . . . . . . 5

Integration Movements in Europe . . . . . . . . . . 5

The creation of the Eurcfean Economic Ccmunity . . . 6

The Ireaty of Rome... . . . . . . . . . . . . 8

Institutional Structure cf the EEC . . . . . . . . . 9

The EEC from the beginairg up to 1968 . . . . . . 12

III. GENERAL GACKGROUND ON ITALY . . - . . - . . . . . . . . . 21

Historic Overview . . . . . . . . . . . . 21

Eclitical Structure................. 26

Economic overview . . . . . . . . . . . . . . 29

Economic Legislaticn..... . . . . . . . . . 43

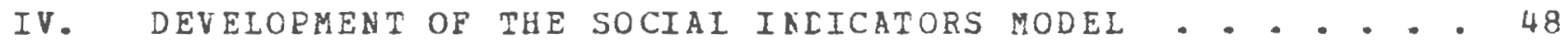

Theoretical Framencrk . . . . . . . . . . . 49

Identification of output descriptive indicators . . . 53

Identification of side-effect descriptive indicators . 58

Identification of policy instrument indicators . . . 58

Identification of nonmanifulable descriptive indicators 59

Model for social system. Identification cí analytic

indicators............... . . 59

Specification of output cescriptive inaicators. . . 61

V. DATA ANALYSIS . . . . . . . . . . . . . . . 83

Output Descriptive Indicators . . . . . . . . 84

Side Effect Descriptive Indicators (output) . . . . 101

Folicy Instrument Indicatcrs (input) ........ . 104

Noñmanipulable descriptive Indicators (input) . . . 109

Analytic Indicators (internal) .......... 118 
VI. COKCLUSIONS - . . . . . . . . . . . . . . . . . 127

Sumary of Besults . . . . . . . . . . . . . 127

Iimitations of the study . . . . . . . . . . 128

A note on Further study ................ 130

BIBIIOGRAFH AHD SOURCES - . - . . . . . . . . . . . . . . 131 
III.1 - Italy: Supply and use of resources 1952-68, annual percentage increases at constant prices . . . . . . 35

III.2 - Italy: Price developments 1952-1968, annual percentage increases

III.3 - Italy: Percentage contribution to expansion of gross domestic product in each period.. . . . . . . 37

III.4 - Italy: Output, employment, projuctivity, wages, unit labor costs, and profits in manufacturing, 1954-1968, annual percentage increase .. . . . . . . . . 39

III.5 - Italy: the balance of payments 1960-1968. . . . . . . 41

IV.I - Output descriptive indicators (Basic human needs) . 55

IV.2 - Output descriptive indicators (Human expectations). . 5 ?

V.I - Indicators relared to nutrition in Italy: mean, slope of regression line and correlation coeficient. . . .85

V.2 - Inaicators related to shelter in Icaly: value and percent change in the periods 1951-61 and 1961-71. . 8?

V.3 - Indicators related to health in Italy: mean, slope of regression line and correlation coeficient . . . 90

V.4 - Indicators related to safecy in Italy:mean, slope 91

V.5 - Inöicators relaced to education in Italy: value ard percent change in the periods 1951-61 and 1961-71. . 94

V.6 - Indicators related to education in Italy: mean, slope of regression line and correlation coeficient . . . 95

V.7 - Indicators related to communication in Italy: mean, slope of regression line and correlation coeficient. 97

V.8 - Indicators related to culture in Italy: mean, slope of regression line ana correlation coeficient. . . 100

V.9 - Side effect descriptive indicators . . . . . . . 102

V.10 - Side effect descriptive indicators(cont.) . . . . 103

V.11 - Policy instrument descriptive indicators . . . . 106

V.12 - Composition of imports/exports (percentage realtive to total)..................... 10?

$\mathrm{V} .13$ - Composition of imports/exports (percentage relative to total)...................... 108 


\section{LIST OF TABLES (cont.)}

V.14 - Total population (in thousands) . . . . . . . . . 110

V.15 - Population by age and sex . . . . . . . . . . . . 112

V.16 - Fertility rate by region (births per 1,000 females). 114

V.17 - Economically active population by major industrial group (in thousands). . . . . . . . . . . . 115

V.18 - GNP, total and per capita of population resident . . . II7

V.19 - Analytic indicators . . . . . . . . . . . . . . . 119

V.20 - Purchasing power of the Italian population . . . . . 121

V.21 - Analytic indicators, consumption indices. . . . . . 122

V.22 - Analytic indicators, consumption indices. . . . . . 123

\section{LIST OF FIGURES}

II.1 - Expansion of GNP. Index of volume for 1958-1963. . . 13

II.2 - Indices of industrial production. . . . . . . . . . . 14

II.3 - Number of unemployed (in thousands) . . . . . . . I5

III.1 - Gross national product in selected countries, 1953-72. 32 Percent changes from previous years at constant prices

III.2 - Growth of GNP and main sectors of demand,1950-72. At 1963 prices, average $1951 / 52=100 .$. . . . . . . 34

IV.I - Social indicator model. . . . . . . . . . . . 54

A - Output descriptive indicators . . . . . . . . . . . Al

B - Side effect descriptive indicators . . . . . . . . . BI

C - Policy instrument descriptive indicators . . . . . . CI

D - Analytic indicators . . . . . . . . . . . . . . . Dl 


\section{Chapter I}

\section{IATROD UCTION}

\section{1 ISSUE STAIEEERT}

The prinary objective of this study is to develop a franerork for a social indicators nodel which can characterize the quality of life at the level of a nation.

Op to a certain extent, the development of such a model is dependent upon the particular application envisaged. For the purposes of illustration, the contry of Italy vas chosen for the application of the general methodology. The assessment focuses on

the inpact on the quality of life in Italy resulting from membership on the European BCononic Consunity (EEC).

\subsection{DETBODOIOGI}

The basic nethodology involved in the present stuay concerns the choice of socio-econonic indicators. Thus, the methodology reguires certain assumptions be established for the social system under consideration. Using the techniques developed and described in the literature cf social indicator theory, indicators are chosen in relation to basic human needs (nutrition, shelter, health, safety, 
leisure) and general human expectations (education, communication, cultures.

For the application considered, data on the indicators to be chosen are collected for two separate periods, one prior to, and. the other subsequent to, the entrance of Italy in the EEC. The time periods considered are 1950-1959 and 1960-1969; this choice was based on two major factors: first, the inclusion of the period of the second world war or of the immediately following years is not appropriate because of the very special impact that the war had on the life conditions in Europe: second, there are limitations on the availability of time for data collection, especially because social indicators were not satisfactorily develcped and systematized. One must be aware of the limitations that result from these factors: tine periods are too short to provide an irrefutable characterization of general trends; they remain (and unequally so) under the influences of the post-war special characteristics; and, the effects of the colicies resulting from the entrance of Italy to the EEC were mostly long ranqe and therefort can only be adequately assessed after a considerable pericd of time. However, even with these limitations, important infcrmation can be provided relative to the objective of the study. 


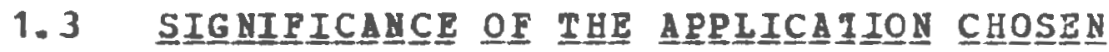

The determination of the impact of EEC memoershif on the quality of life of the population of a ccuntry is a most important problem at the present time. Most of the studies of tinis subject are based strictly cn economic and political factors. It is, therefore, of considerable importance to assess directly, by social indicators, the eifects on the quality of life in the country.

The proposed application is cef particular interest at a time when two countries, portugal and spain, are seeking membership, and, a third ccuntry, Greece, is going through its beginning years in the comunity ${ }^{1}$ - Juging frcm recent Eurocean history, the entrance cf these countries to tre $\mathrm{EEC}$ is certain to be the most important factor in botb of tineir socio-economic and political futures.

The three countries abcve menticned are situated in southern Europe and they appear to have structurai characteristics more similar to those of Italy than of any cther country presently belonging to the community. The issue is cf special interest to the author, a portuguese citizen, because this study may provide indications useful for the analysis of the pctential impact on portugal relative to her participation in the commuity. It is hoped that the results of further elaboration of the model can be employed to analyze the potential for change of quality of life that could be expected should portugal join the commuity, as well as to monitor observed changes foilowing membership.

1 Greece joined the community in 1981. 


\subsection{ORGANIZATION OF THE TEXI}

The social indicators model developed in the present study is applicable to other countries with some modifications. However, it would be misleading to carry out its application without mentioning the general characteristics of the social, econom Ic and institutional ilfe of both the EEC and Italy, joth before, as weIl as during the time periods chosen for the data analysis. In fact, the understanding of the limitations cr drawbacks of such an analysis requires the consideration of the overall situation in the system under analysis. on the other hand, the gatbering of data and the understanding of their significance, aiso requires a certain general knowledge of the socio-economic systen being considered. These facts dictated the inclusion of two general chapters providing background information on the econolic, social and institutional structure of the EEC (second chapter) and Italy (third chapter).

The fourth chapter carries out the deveiopment of the social indicator model for assessing quality of life. after describing the methodological bases for such a process.

The data analysis is carried out in Chapter $V$. After a presentation of the data on the used sccial indicators for the two time periods considered (before and after Italy's entrance to the EEC), comparisons are established betwe $\in \mathbb{n}$ values and trends.

In the sixth, and final, chapter the findings are presented and the limitations and drawbacks of the study are discussed. Directions for further york in this area are noted. 
Chapter II

GENERAI BACKGBCOND ON THE EEC

\subsection{INTEGBATIOI MOYEEENTS IN EㅁEOPE}

The movement towards socio-ecoromic integration of Europe, although golng back to a distant past, received renewed attention in the years following the end of the second world war. There was a growing awareness of the desirability of creating supranational institutions that would attenuate the nistorical animosity between several of the European states, and would establish a sufficiently large political and economic entity able to negotiate with the United states of America and the Soviet union from an European stand.

The first concrete step towards economic unity in Europe was taken by the formation of the Berelux, a customs union created by Belgium. Luxembourg and the Netherlands in 1947. In the following year (1948). the organization for the European Economic Cooperation (OEEC). inccrporating seventeen ccuntries, was established with the inmediate purposes of liberalizing trade and of allocating the economic aid for the reconstruction cf post-war Europe which it was receiving from the U.S.A. under the Marshall plan. However, this cooperative organization did not frovide ar adeju te institutional framework for economic unity. 
The members of the Benelux together with France, Italy and West Germany established in 1952 a ccmmon market for coal and steel, called the European Coal and steEl Commity (ECSC), which abolished tariffs and guotas on these products in the trade among the memper states. The ECSC played a very impcrtant role in preparing the ground for a broader economic unity in Europe.

In 1954, an attempt was made to create a European Defense Community and an associated political ccmmunity aimed at achieving European integration in terms of commor derense and political interests. The failure of this attempt called attention to the difficulties involved in establishing poittical integration in a continent wh such varied regional interests and with such strong nationalistic positions of the meaber countries. This failure, in conjunction with the success of the ECSC, suggested that the establisiment of a broader supranaticnal organization should be based primarily on economic factors and should aim at protecting the member states against unfarorable eccnomic and social situations.

\subsection{TEE CBEATION OF TEE EOROPEAN ECONOMIC COMMONITY}

The six members of the ECSC agreed in 1955 to create a full economic unicn and to unite their efforts in the peaceful uses of atomic energy. A comittee was charged with preparing a preliminary report on these tro initiatives. This report was eventually named after the president of the comittee. The so called spaak report emphasized the economic acivantages of a larger market, in 
particular the tigger productive tase and the increased division of labor which would result. It was believed that the achievement by Europe of an economic and political stature comparable with the United states of America and the soviet mion, would be more effective by tine establishment of a ccmon market than by a free trade organization similar to the DEEC.

Three wajor actions were consicered in the spak report as essential for the success of the ne initiative: 1) the abolition of obstacles tc free trade; 2) the establishment of rules of competition. including joint policies tc deal with balances of payments, monopcly control and state competition; 3) the enhancement of European resources through the aid tc regional development of underdeveloped areas, the absorption of rass unemployment, the productive reconversion of industry and labor, and the fiee movement of capital. labor and services.

official regotiations among the six countries of the ECSC took place in 1956 and resulted in the preparation or two treaties: the European Econcmic Commuity (EEC) and the European Atcmic Energy Community. On March 25. 1957, the treaties were signed in Rome and, by the end of that year, they were aprooved by the respective national parliaments. The EEC treaty began to be applied in 1958 and the institutions of the comurity were immediately created in Brussels. 


\section{3 IEE TEEATY OF BOUE}

The Treaty of Rome focused cr measures to introduce a common market and on provisional procedures necessary for the transitional period. It does not contain any IEference to defense. foreign policy or dcmestic administration which were to be of the responsibility of the individual member nations. The core of the legislation in the Treaty is concerned with the establishment of a customs union. A customs union differs from a free trade area in that, in addition to free trade among its members, it also provides for a comon external tariff against imorts from outside countries. The Treaty of Rome provides for more than a mere customs union, as it envisages the ultimate merging cf the economies of its members. This was to be achieved by a llowing the free movement of labor, capital, and enterprises, betweer the member states. The Treaty called for an initial transitional period of twelve years which would provide for the progressive establishment of the customs union in three four-year stages, to be finished by the end of 1969.

The document also contains provisions relative to the estabishment of ccmion policies in agriculture, transpcrtation and the control of distortion in competition. It includes references to a common social policy, the creation cf an European social Fund for the improvement of emplopment opporturities, the raising of standards of living and the levelling of living and working conditions in the upward drection, the creation of an Eurogean Investment Bank for the financing of projects for developing less developed regions and modernizing or converting enterpises. The structure and institu- 
tional mechanisms of the community, which is the focus of the following section, are also defined in the Treaty.

A certain number of protocols were signed by the member countries at the same time as the Ireaty of Rome regarding particular dispositicns. one is of specific importance to Italy. It was agreed that the institutions of the community should put into effect "all means and procedures" for heiping Italy to carry out a ten-year prcgram of economic expansion for the correction of structural imbalances in Italy. especially by the development of the Southern regicns of the country.

\subsection{INSIITUTIONAI STRUCTURE OE IEE EEC}

The main institutional components of the EEC, as stipulated in the Treaty cf Rome were: the Assembly, the council, the commission and the court of justice. A convention signed by the member states, after the rreaty of Rome, established that a single Assembly and a single court of Justice would be shared by the three EuIopean Community crganizations: EFC, Euratom and ECSC.

\section{a) hㅡㄹ $\underline{\text { s sembly }}$}

Composed by delegates from the Parliaments of the member states in numbers stipulated in the Treaty, the Assembly had the responsability of discussing the annual gereral report submitted to it by the commission, and could issue motions of censure concerning the activities of the commission which, if approved by two-thirds of its members, would force the resigration of tine comission. 
The Commision could attend and address the Assembly meetings and was required to reply to questions formulated by the Assembly or its members.

\section{b) Ihe Council}

The Council was composed of delegates of the governments of the member states. It was invested with decision power regarding the commuity affairs and had the resfonsibility cf ensuring the coordination cf the general economic fclicies of the member states.

\section{c) The Conission}

The commission was composed cf nine members chosen for their general ccopetence and indisputable independence (no more than two with the same nationality), and afpointed by the governments of the member states acting in common agreement. Their term of office was four years which could be renewed. The members of the commission had to carry out their duties in the general interest of the community and with complete independence, without seering or accepting instructions from any Government cr other body.

The commission had the responsitilities of: ensuring the application of the provisions of the Ireaty or tine ones enacted by the instituticns of the ccmmuity, formulating recommendations or opinions in matters of the commuity interest, exercising its own executive power in accordance with the provisions of the Treaty and the determinations of the council, and participating in the preparation of acts of the council or the Assemby. An annual report on the activities of the communty was to be prepared by the comission and submitted to the Assembly. 


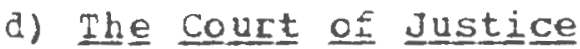

The Court of Justice consisted of seven judges, appointed for terms of six years by the governients of the member states acting in commor agreement. They were selected as persons of indisputable independence who fulfilled the corditions reguired for holding the highest judicial office in their respective countries. The court was assisted by two advocates-general, chosen by the same procedure as the judges. whose role was tc give impartial reasoned opinions on each case prior to the deliberations of the court.

The Court of Justice was the guarantor of justice and the law in its interpretation and application of the Treaty. It was to rule on matters submitted by the commission, the council, the Assembly or any Member state, regarding such matters as the application of the Treaty, the exercise of the irstitutions of the community, and cases between the community and its employees.

\section{e) otiner Ccmmunity Institutions}

Several auxiliary and consultive bodies were provided for in the Treaty of Eome: the Economic and Social committee, The Monetary Committee, the Transport comittee, the European Social Fund, and the European Investment Bank. 


\subsection{THE EEC FROM THE BEGINNING 므 TO $19 \underline{6} \underline{8}$}

The first five years of the EEC were characterized by marked advances ir all the major economic cevelopmert objectives established in the Treaty of Rome. In fact, the community grew faster than any other major economic area in the hest, stimliating increases in the gross national products, producticn, consumer purchasing, employment, trade, and overall economic strength of its members. Between 1958 and 1963, the gross community projuct grew by about $30 \%$ (compared to $22 x$ in the U.S.A. and $16 x$ in the United Kingdom), the index of industrial production rose by $41 \%$, the general standard of living in terms of real private consumption per capita went up by $23 \%$, the internal trade by $130 \%$, ard, in the trade with ronmemer countries, imports increase d by $51 \%$ and exports by $35 \%$ (see figures $I I-1$ to $I I-3)$

During this period, several rew commuity institutions were created, all of them incorporating representation from the member governments and the commission. Trese included:

- the Administrative comassion for the Social security of Migrant workers, supervising the social security arrangements for comonity citizens working in a member country other than its own,

- trie comittee of permanent Representatives, set up in 1958 with the main task of preparing the meetings of the council and performing whatever functions the council wished to de legate to them, 


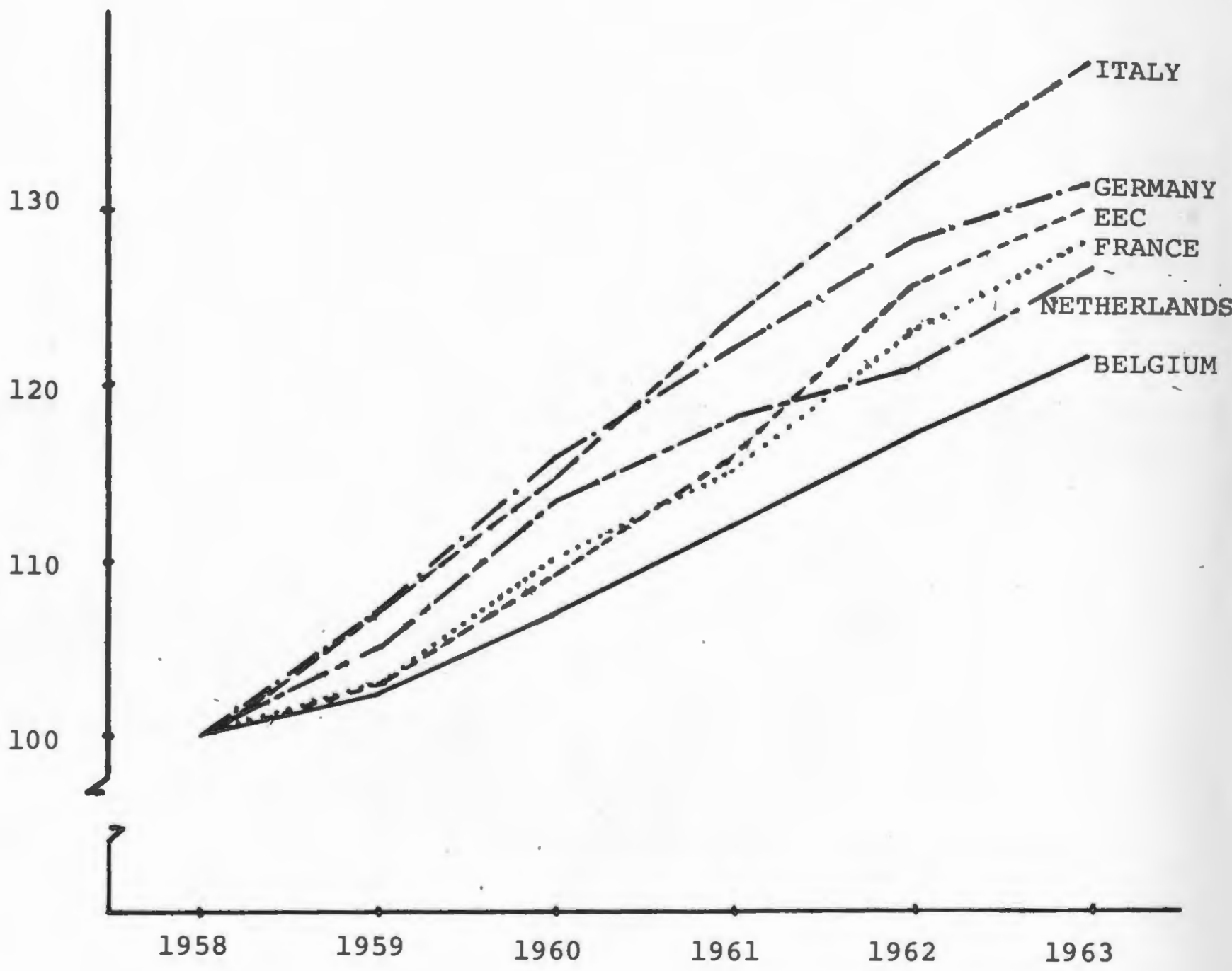

Fig. II.l - Expansion of GNP. Index of volume for 1958-1963. ( $1958=100$ )

Source: Weil, G.L. (editor) A Handbook on the European Economic Community Frederick A. Praeger Publishers, New York, 


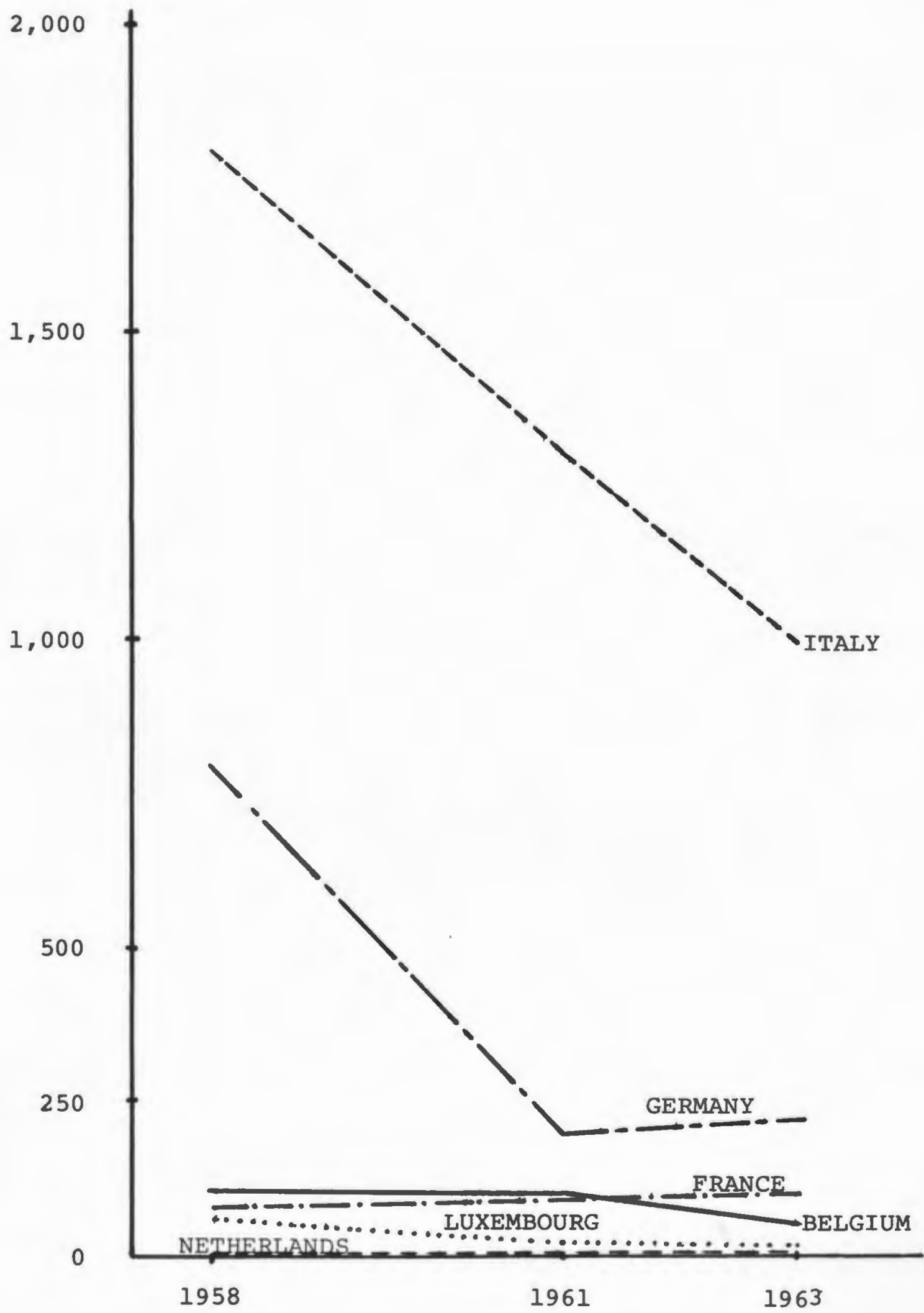

Fig. II.3 - Number of unemployed (in thousands)

Source: Weil, G.L. (editor) A Handbook on the European Economic Community Frederick A. Praeger Publishers, New York, 1965 . 
- the special Aqricultural ccmittee, set up in 1960, whose main responsibility was the discussion of agricultural matters to be later reviewed ky the councii,

- the Short-term Economic Fclicy Comittee, set up in 1960 with the task of assistinc in the coordination of the dayto-day economic policies of the community.

The creation cf these comittees was regarded ith great suspicion by the persons favoring a strcig suprarational organization. Such an organization was to control the affairs of the community with independence trom the particular follcies of the member countries. However, in pratice, the committees actually reiniorced the Commnity and permited further develofuent in the integration movement.

The rapid growth of the community economy during 1958-63 created inflationary pressures that limited the pace of future development. The member states, in cooperaticn with tre commission agreed to take concerted countermeasures, involving ronetary and financial policies, as well as medium-range economic planning and programming.

In 1962, a common agricultural policy was initiated with the objective of extending the common rarket to agricultural goods which was to be completed by the end cf 1969. The negotiations for a common agricultural policy preserted serious difficulties due to the many differences in agricultural characteristics and regulations of the different member states. However, agreement was eventually reached. 
The major task auring the iritial years of the EEC, as fixed by the Treaty of Rome. was the establishment of the customs union within a transitional period of thelve years. Actually, by a proposal from the commission, this process was accelerated in relation to the fixed schedules so that by the end of June 1968, the customs union was compietely achieved - - ore year ard cre-half ahead of the scheduled date.

Dn balance, the first years of the E $\mathrm{IC}$ were highly positive, as can be seen from the deveiopments related above. However, several difficulties fresented real threats to the continuity of the commnity. The most serious crises occurred ir relaticn to france, then under the presidency of de Gaulie. These difficulties were triggered by the British applicatior for membershif in the communty ${ }^{2}$ (1961) and the EEC constitutional crisis following a commission proposal cn farm financing and Commuity budgets (1965).

The United Kingdom application to membership received considerable attention by the EEC. At first it was progressing favorably, but in January 1963 de Gaulle opfosed the Eritish entrance to the EEC in a press conference. The French decision was based on the difficulties of accomodating the disparate agricultural structures of the tro countries. However, it was also very much influenced by General de Gaulle's vision of a strong European block under the leadershif cE France and by his suspicion of the possible influence of the U.S.A. on the community, through her leverage on the United Kingdom. France used its "veto" in an unilateral way, without pre-

2 In the same year Ireland and Dermark also appiied to membership. 
vious corsultation with the other members cf the commuity. This posture violated the spirit that had existed previously in the community and created a serious crisis of confidence. A first reaction on tie part of the other menter states was to attempt to stop measures thought to be of interest to france. In the spring of 1963. this led to a policy, propcsed by Germary, of "synchronization" ố reciprocal concessions, tying measures cf special interest to France with measures of interest to the other countries. The adoption ot the "synchronization" frinciple was, in fact, an acknowledgement of the crisis of confidence witiin the community. It did prove successful, however, in maintaining the operations of the organization up to 1965 .

on April 1955, the member countries agreed on changing the institutional structure of the commity in view of an eventual merger of the three Community crganizations (ECSC, EEC, and Euratom). It was decided that, begincing ir. July 1967, a single comission and a single council would be estaklished ard a transitional period would be initiated leading to the effective merger of the three entities by july 1970. In the same treaty, the council received the official name of Council of Ministeries, the Assembly received the name of European Parliament, and the Comattee cf Permanert Representatives was formalized.

The most serious crisis of the EEC occurred, however, in 1965 and resulted from an attempt to fursue the "synchronization" policy. In June 1965, the Commissicn tried to link three policy measures in a package deal: the ccarletior oi the farm finance regu- 
lations, strongly desired by France; the financing of the community by its cwn resources, strongly desired by the commission; and the granting cf greater budgetary powers to tre Assembly, demanded by the Assembly ard by the Netherlands and later also supported by Germany. France opposed alone the consideration of these proposals in a single package and tried to fut the priority on the first of the three items. This attitute was taken because France saw the budgetary independence of the ccmmuity's supranational institutions as a threat to her considerable influence in the commuity, and, because the issue of farm financing was cf extreme importance for the ccuntry. The aim of tine French move was therefore the separation of the three matters sc that the farm financing issue could be approved ard the others rejected. Agreement on tisis discussion was not reached and by June 1965 France decided to absent her ligher level officials from future meetings of the council. Instead, junior representatives were sent to meetings or written procedures were used to transact rcutine business. This situation continued for a period of seven mcnths, during which France called for a qeneral revision of the institutional structure of the commission. However, after de Gaulie was confronted with internal polltical difficulties during $h_{i} \leqslant 1965$ Presidential campaign, it vas possible to resume normal frccedures with france as a member of the community. An agreement was reached which covered two main subjects: the role of the commission, and, the question of majority roting in the council las opposec to a consensual form of operation). The Erench "boycott" did not achieve an alteration of the Commuity's constitutiol, but it did succeed in postponing budgetary questicns until 1970. 
In spite of all these difficulties, the IEC established itself as a viable supranational entity, with increasing pover over the economies of the member states and with the reinforcement of its independence from rational governments. An indication of this tread is the extension of the commission executive role as observed throughout time. Eetween 1958 and mid-1962, a total of 55 common Market requlations came into force, of which only nine were issued by the Commission. Between July and october 1962 the commission adopted 70 regulations on its own and, two years later, it was issuing 120 annual regulations.

The European economic integration has been fursued since 1968 leading to the added membership of various other countries. 


\section{Chapt $\in$ I II}

\section{GENERAL BACKGEODND ON ITALI}

\section{1 HISTORIC OYERYIEE}

The major characteristics of Italy which require historical perspective for the present study, are the existence of sharp regional, social and economic contrasts throughout the country. The following overview is intended to describe these characteristics while also providing historical information for the understanding of the Italian situation for the study period.

During the Middle Ages. Italy became civided in numerous rival independent states, a situation which persisted up to the 19 th century. Several factors contributed to delayirg national unification efforts. The dominant groups in the numerous principalities, city-states, and aristocratic republics wanted to maintain their privileges, particular interests and power. They not only ofposed unification with the other states, but they also resisted the creation of a modern centralized administration, inside their own states, as this would put an end to the existing feudal organization. Cn the other hand, both the Roman Empire and the Catholic Church, the major institutions irfluencing Italy in her early history, encouraged cosmopolitan, rather than nationalistic attitudes. The Catholic church, whie attempting to control extended 
areas of the peuinsula and not beirg able to do sc, had, however, the sufficient power to keef others from gaining widespread political contrcl, and did not hesitate in asking the help of central Europear states for that purpose. Furthermore, the succass of the Foman Empire and, later on, of the important city-states, like Genoa, Florence and venice, relied substartially on the use of rural resources to support the radiant life in the towns. These characteristics of exploitation and offressior ir tie urban-rural relations persisted in Italian life uf to recent years.

Duriag the Renaissance, the failure of coordinating efforts in Italy resulted in foreign domination of extensive areas of the peninsula, first by spain and later cn by Austria. In order to maintain their influence, these two fcreign powers fursued a successful game of flaying the different Italian forces against each other. At that time the Mediterranean trade routes were being replaced by those of the Atlantic. The resulting state of the economic affairs in Italy, accompanied by the cultural torpor imposed by tine foreign rule and the Inquisition, createc a situation of marked political passivity.

The effects of the political events in France in the late 18th century and the beginning cí the 19th century, namely the French Revolutior and the Napoleonic Empire, very strongly influenced Italy, as they did influence almost all other suropean countries. It was under this influence that a feriod of revolutionary agitation beqan around 1820 in the Northern kingdom of Piedmont, which eventually led to the political unification of the ccuntry between 1859 
and 1870. However, the political unificaticn cí the country did not have much effect on the interregional imbalances within Italy and de facto urity was not achieved. The reasons for this are deeply rooted in past regional imbalances whict. were reinforced by the fact that the unification movemert was predominantly a bourgeois undertaking controlled by the corstitutional kingdom of piedmont. The Northern bourgeoisie, seizing the revolutionary ardor of repubIican democrats, but neutralizing their political influence, gained control of the administration thrcughout the country for several years. Still under the regime of a constitutional Monarchy, economic develofment was oriented towards industrial competion with the rest of Europe. At the time, the Industrial Revolution had barely began in Italy -.- a country with $75 \%$ of the total population illiterate, a railroad syster with only $2,500 \mathrm{~km}(1,550$ miles) of railroad tracks, an industry in the handicraft stage, and custom barriers obstructing the trade betweer the several states. The considerable amount of funds needed for the industrialization effort were made possible by beavy taxation of the agricultural sector. The new economic development benezited tine bouryeoisie of the Northern regions the most at the expense of the countryside and, in particular, the southern regions. The regions not only were predominantly agricultural, but they were also much less industrialized and could not benefit directly from the overall industrialization effort. consequently, the initialiy wide gaps between the North and the soutb. Letween urban and rural areas, and between different social grcups, were further widened. 
Between the period of urification and the beginning of the first World war in 1914, the life in Italy was characterized by economic instability. Periods of consideratle economic development, almost exclusively in the Northern regions of the country, alternated with periods of economic crisis characterized by inflation, low wages and unemployment. During this, the population was markedly increasing, particularly in the scuthern regions. The periods of economic crisis were usually acccmpanied by exigration to foreign industrialized courtries, by sccial unrest, and by extensive strixes in the industrial areas. This unrest invariably started in the south and propagated to the Ncrth. These factors sharpened the imbalances verified between different regiors and social groups.

Italy's farticipation in the First world war unfavoraily influenced the economy. A deep recession led to the bankruptcy of several impcrtant enterprises, to un $\in$ pployment and low wages. The increasing social unrest created a serious situation of widespread revoit. The poitical parties on the left were radicalizing at the same time: the commist party appeared and a strong marxist wing of the socialist party was formed. At the governmental level, a period of high instability also cccurred. Four different governments vere installed in a period cf three years.

The Fascist movement began as a reactior against the threat of revoluticnary Marxist forces and the liberal bourgeois principles of tre french Revolution. Initially orientated toward anarchosyndicalism, the Fascists used violence to destroy the socialist activists anō trade unions, and created an atmosphere of fear. The in- 
dustrialists of the North saw in the rew movement a way of controlling the workers, and lent their support. By recruiting the unemployed with cffers of money, the Fascists were able to gain power in 1922. They successfully establishel a dictatorship based on the principles of the supremacy of the state, nationalism and coorporativism, and opposing raticnalism, intellectualism, individualism, parliamentarism, democratic pluralism and Marxism. This dictatorsip was only to end at the conclusion of the second World War.

From the economic point of vien, the Fascist dictatorship can be divided into four periods. The first period (1922-1926) was characterized by liberal policies and the dismantiing of the regulatory mechanisms of the First Horld har. It was a period of a considerable economic improvement. A period of strong governmental regulatory policies (1926-1930) followed when predominantly political objectives were pursued. Several "econonic battles" were waged, but none had visible success. The third period was characterized by autarchic policies (1930-1940), with strong regulatory measures being taken to achieve self-reliance and economic independence from foreign markets, Finally, a rafid deterioration of the economy, accompanied a period of war (1940-1943). The country surfered extensive damage during the vaf (atout $1 / 3$ of Italy's wealth) that resulted in a gross national prodcct one-helf of the value attained in 1939.

The Fascist dictatorship had infosed an apparent unity and calm by the use cf force, tut once its domination ended, the deep re- 
gional, sectorial and social divisions emerged again undiminished in strength.

The Reputlic was established in 1946 following a national referendum, ard a constitutional Assembiy was elected which produced the Republican Constitution of 1947. For sixteen years (1947-1963) the Christian Democratic Party contrclled the government. From 1963 until 1970 a coalition of the Christian Democrats and the socialists took charge of the government. Aithough suffering from signiEicant political instability associated with the difficult politics of the coalition, the governments during this period were able to pursue a considerable stabilization of the economy and of the democratic state.

\subsection{POLITICAL STROCTURE}

The present Italian Constituticn decreed, on January 1, 1948, the displacement of the Italian Monarchy by the Italian Republic. This document establishes for Italian citizens individual rights and duties, and the general fclitical structure of the country. The main elements of this structure are two legislative bodies (Senate and Chamber of Deputies). the President of the Republic, the Governant and the courts.

The senate and the Chamber of Leputies have 315 and 630 members, respectively. A majority of the senators and all the Deputies are directly elected by Italian citizens. The non-elected members of the senate are former presidents ct the Repuriic and five individu- 
als appointed by the Italian President for their cultural or scientific stature. Besides their legislative functions, these two assemblies supervise the government and may grant or withhold their confidence in the cabinet.

The President of the Refublic is elected by a joint session of the senate and the Chamber of Defuties. The Italian president is much less pcwerful than are the American or the French presidents. He can, bowever, dissolve the legislative assemblies. The presidential functions include: the authorization to introduce governmental bills to the parliament, the promulgation of legislation passed by the parliament or goverrmental decree, the appointment of the Prime Minister (Presidente dei Consiglio di Ministri), and the approval of the ministers proposec by the latter.

The Government is composed of the Prime Minister, 19 ministers charged with individual sectors of the administration (Internal Affairs, Defense, Justice, Foreign dfairs, Foreign Commerce, Budget and Economic Planning, Finance, Treasury, Education, Public Works, Industry and Commerce, Agriculture and rorest, Iabor and Social Security, Transfortation and Aviaticn, Merchant Marine, post offices and Teleccmmunications, State Holdings, Health, and Tourism and Exhibitions), and several ministers without portfolio (such as ministers for Eureaucratic Reform, Scientific Fesearch, Parliamentary Relations, and southern Italy). The government has the responsibility of presenting to the legislative branch a detailed program for its act Ivities, and may intrcduce bills to the parliament and issue Decrees-law in exceptional circumstances and in accordance to 
the constitution provisions. Interministeriai comittees are also important components of the goverrmental structure. They are usualIy appointed to solve specific froblems related to the economy. Italy's governmental system is decentralized in 20 regional governments with administrative and legislative power in specific areas (e.g.. agriculture, tourism, urban development and forestry). Local governments (in provinces and commures) are composed or members locally elected and have only administrative power. Their acts are subject to the approval of a perfect or a Board appointed by the national government.

The Italian court system is composed of civil, Criminal and Administrative courts. The constitutional court (Corte Constituzionale) supersedes all cther courts ard is resporsible for issues related to the Regions, and to the higher organs of the state.

The pclitical arena in Itaiy includes several parties which range from left to right. At the center is the christian Democratic party (DC), which has been the core of the government since 1945. To the right of the DC, the important political formations are the Liberal Party (PLI), the Italian Social Movement (MSI), which is neofascist, and the Italian Democratic Party of the Monarchist Urity (PDIUM): to the left of the DC the most important parties are the Italian socialist party (PSI), the socialist Party of the Prcletarian unity (PSIUP). the communist Party (PCI) and the Republican Earty (PRI). 


\subsection{ECOHOHIC OYEREIEE}

Italy's participation in the second horld war as an ally of Germany is an important factor for the understanding of the economic characteristics of the period $u n d \in$ analysis in the following chapters $(194 \varepsilon-68)$. When the war ended, the country was faced with severe uremployment, high inflaticn, serious slortages of many commodities, and a disrupted industrial structure due to extensive war damage. onemployment was running as high as $12 \%$ of the working population throughout the entire ccuntry, and, in the south, it reached $17.5 x$.

To the immediate problems faced by postwar Italy, one must add the problems that resulted from the structure of the Italian economic system at the time. The fascist government, which remained in power between 1922 and 1943, pursued economic policies that produced an autarchic system under strict governmental regulations. The centralization of econcmic çecisions, a feature of fascist ideology and folitics, was furtheI aggravated by the need for governmental intervention for a corcerted war effort. Furthermore, the industrial sector was comparatively weak in the overall economy of the country. The traditional and technologically backward industries, such as food-processing and textiles, dominated, while aqriculture was excessively concentrated in cereal production.

The recovery period, following the war, was characterized by the onset of liberal economic policies interded to restore "free market" mechanisms and to develop "modern" industries, such as automobile steel and chemical industries. A progressive dismantling of 
the Fascist controls, protectionism and autarchy was carried out. The develcpment of "modern" industries required an increase of foreign trade, since raw materials such as iron ore, petroleum, coal and timber were scarce, and the dcmestic market did not have sufficient capacity to make economies cf scale and specialization viable.

The return to the "free market" systen was, of course, accompanied by speculation in tine comodity and finarial markets, which Eurther enhanced inflation. Alternatively, foreign trade, which had been completely controlled by the government, was liberalized by the creation of two foreign exchange markets, one controlled by the government and the other subjected to a "free market" operation. These two foreign markets conduced to multiple exchange rates with associated speculations and distortions. only when inflation and deficits in the balarce of payents attained intolerable values was serious interventicristic corrective action taken by the qovernment. Financial measures which involved the reduction of liquidity by a partial treeze of tank deposits and by the coverage of Imports with foreign exchange reserves. This difficult financial situation was aleviated in 1548, when U.S.A. aid in the form of the Marshall plan came to suppcrt the Italian currency and economy. The liberalization of forejgn trade and the integration into European markets was then pursued by tre entrance of Italy into the European Coai and steel Commuity 1951) and tíe European Economic Compunity (1958). 
The econcic liberalization pursued duriny the recovery period was important in the modernizaticn of an economy directed to the foreign markets, but its opfositicn to the creation of planning institutions and instruments led tc the reinforcement of structural problems and had an adverse effect in subsequent years.

The dismantling of regulatory controls and governmental protectionism was expected to reduce governmental spending, bureaucratic mismanagement, redtape, and corruftion. However, as in other countries that have experienced similar situations, this process of dismantling governmental interventicn created its own organizational needs, bureaucratic offices and red tape, while leaving room for new forms of corruption. Thus, the structural and organizational deficiencies of the government persisted, aggravated by an almost complete non-existence of institutionalized pianning ${ }^{3}$.

In the period between 1951 and 1963, which has been called the Italian "economic miracle", the increase in the gross national product (GNR) exceeded all other Eurcpear couritries, witi the exception of Germany (see Fig. III-1). The observed increases in GNP were not particularly high, but, wile most countries experienced sharp downturns during different feriods, Italy maintained a steady increase. During this period of rapid economic growth, the most dynamic sectors of total demand were fixed-capital formation and exports. In fact, aggregate demand (GNP growth plus imports) increased at an average annual rate oI $63 \%$, and contributed to

3 Only in 1966 was the first five-year plan introduced in Italy, and it was extremely inefficient. 


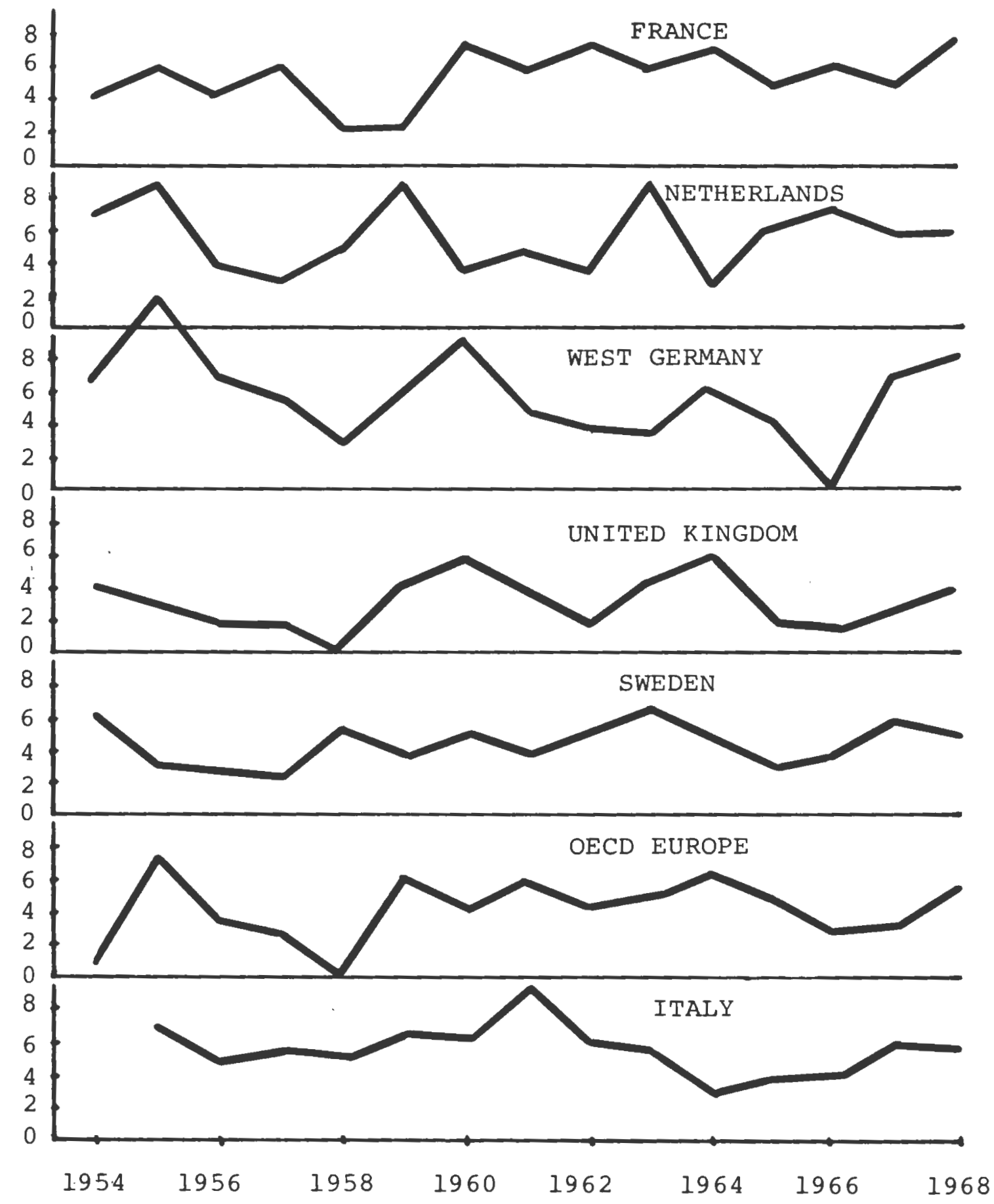

Fig.III.I - Gross national product in selected countries, 1953-1972. Percent changes from previous years at constant prices.

Note: Except for Italy, the figures for 1972 are estimates. Sources: Italy: ISTAT, Annuario di contabilità nazionale(1971) Ministero Del Bilancio e della Programmazione Economica, Relazione Generale (1972)

Other countries:O.E.C.D. Nationale Accounts of O.E.C.D. Countries.

In Podbielski,G. Italy: Development and Crisis in the Post-War Economy Clarendon Press, Oxtord,1974. 
fixed-capitai formation and to exforts by rates of 1.5 and 1.2 percentage pcints, respectively. Private consumption rose more slowly than either total demand or GNP (see Fig. III-2 and Table III-1). This period was also characterized by a high degree of price stability (see Table III-2).

The importance of foreign trade in the Italian economic recorery is illustrated by increases in the ratio imports/GNP from $7.4 \%$ in 1951-52 to 14.3\% in 1961-62, and in the ratio exports/GNP from $6.2 \%$ to $14.5 \%$, in those years. The accelezation of foreign trade had a direct impact on the economy by consolidating the balance of payments, and an indirect impact by stimjlating industry to utilize mass production metiods and to introduce advanced technology, both of which were required for successful competition in foreign markets.

In order to identify the factors that determined the economic growth of the period, it is useful to consider Denison's study of the sources of growth in several ccuntries (Denison, 1967) which is sumarized tor Italy in Tarle III-3. The mcst important factors are the apflication of knowledge in 1950-55 (having "caught up" with the cther developed countries), tise improved allocation of resources (mainly due to the significant shift of labor from agriculture to industry), and the develofwent of economies of scale, with the last two having increasing importance during 1955-62. The availability of a large, under-utilized labcr sufpiy contributed to the marked expansion cbserved. I mportant increases in productivity were made possible by the employment of wozkers in new sectors, by 


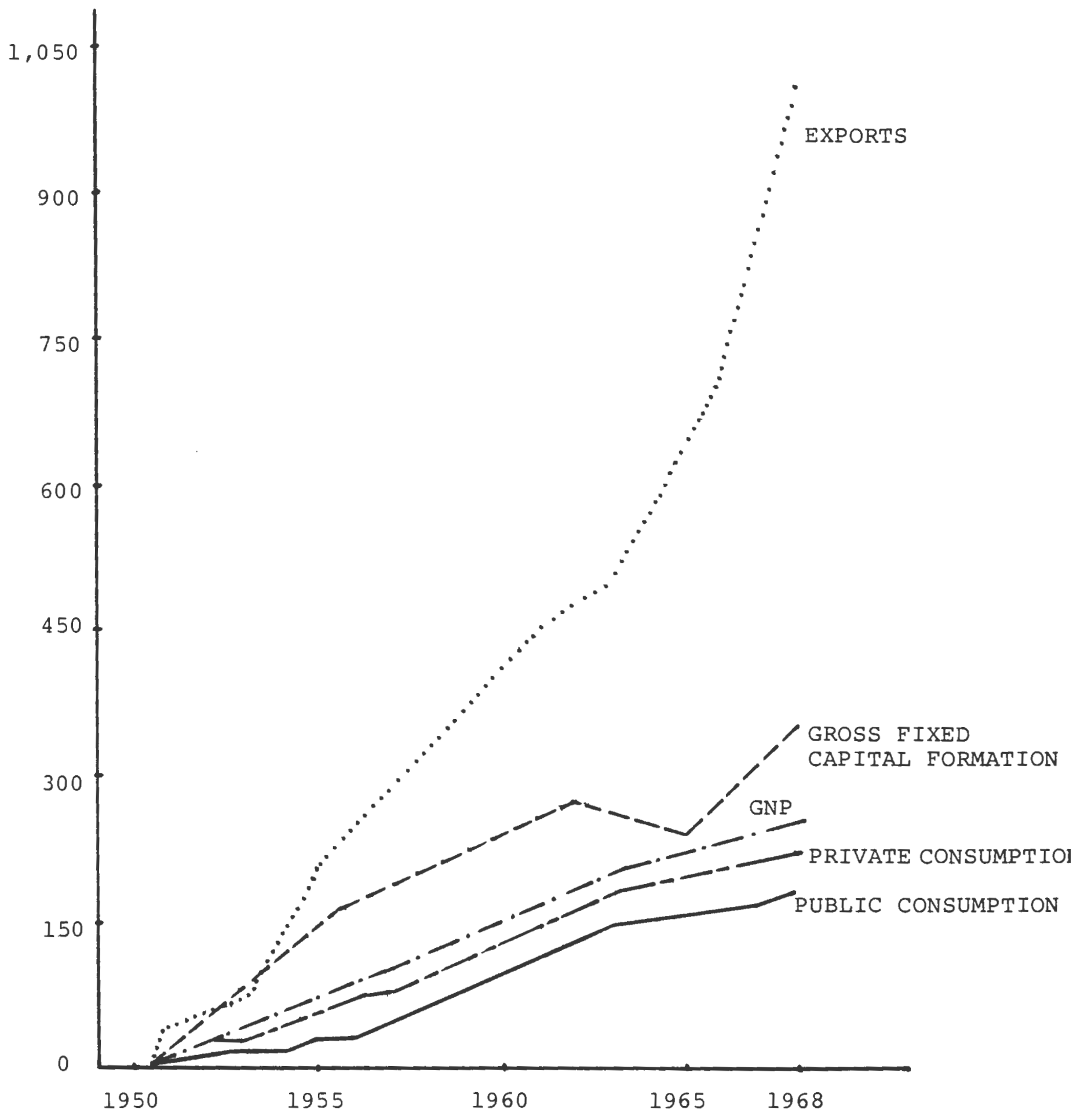

Fig.III.2 - Growth of GNP and main sectors of demand,1950-1972. At 1963 prices, average 1951/52 = 100 .

Source: ISTAT, Annuario di contabilità nazionale (1971).

In Podbielski, G. Italy: Development and Crisis in the

Post-War Economy Clarendon Press, Oxford, 1974. 
Table III.I - Italy: Supply and use of resources 1952-68, annual percentage increases at constant prices

\begin{tabular}{|c|c|c|c|c|c|c|c|c|}
\hline & $\begin{array}{l}1952-62 \\
\text { average }\end{array}$ & 1962 & 1963 & 1964 & 1965 & 1966 & 1967 & 1968 \\
\hline $\begin{array}{l}\text { RESOURCES } \\
\text { GNP at market prices } \\
\text { Imports of goods and services } \\
\text { Total }\end{array}$ & $\begin{array}{r}5.9 \\
13.5 \\
6.2\end{array}$ & $\begin{array}{r}6.3 \\
16.4 \\
7.5\end{array}$ & $\begin{array}{r}5.4 \\
22.4 \\
7.6\end{array}$ & $\begin{array}{r}2.9 \\
-5.1 \\
1.7\end{array}$ & $\begin{array}{l}3.6 \\
1.9 \\
3.4\end{array}$ & $\begin{array}{r}5.9 \\
13.7 \\
7.0\end{array}$ & $\begin{array}{r}6.8 \\
13.1 \\
7.7\end{array}$ & $\begin{array}{l}6.4 \\
7.5 \\
6.6\end{array}$ \\
\hline $\begin{array}{l}\text { UTILIZATION } \\
\text { Private consumption } \\
\text { Public consumption } \\
\text { Gross fixed capital formation } \\
\text { of which: } \\
\text { Residential construction } \\
\text { Other construction } \\
\text { Machinery and plant } \\
\text { Transport and equipment } \\
\text { Exports of goods and services }\end{array}$ & $\begin{array}{r}5.0 \\
3.8 \\
10.2 \\
13.0 \\
8.8 \\
9.1 \\
10.4 \\
13.7\end{array}$ & $\begin{array}{r}6.5 \\
5.4 \\
10.1 \\
\\
15.4 \\
12.6 \\
8.3 \\
9.1 \\
12.3\end{array}$ & $\begin{array}{r}8.9 \\
4.6 \\
8.1 \\
\\
12.1 \\
0.4 \\
7.4 \\
22.3 \\
6.9\end{array}$ & $\begin{array}{r}3.0 \\
3.6 \\
-6.4 \\
\\
6.9 \\
-3.0 \\
-18.7 \\
-11.7 \\
11.6\end{array}$ & $\begin{array}{r}2.7 \\
4.0 \\
-8.6 \\
-6.2 \\
-2.1 \\
-19.5 \\
-5.1 \\
20.1\end{array}$ & $\begin{array}{r}6.8 \\
3.2 \\
4.0 \\
-1.3 \\
2.6 \\
14.7 \\
0.3 \\
13.2\end{array}$ & $\begin{array}{r}7.1 \\
4.3 \\
11.8 \\
\\
5.6 \\
10.4 \\
15.6 \\
24.6 \\
6.7\end{array}$ & $\begin{array}{r}4.9 \\
4.1 \\
9.7 \\
11.9 \\
6.5 \\
9.8 \\
11.2 \\
15.4\end{array}$ \\
\hline
\end{tabular}

Sources: ISTAT, Annuario di contabilità nazionale (1971); Ministero del Bilancio e della Programmazione Economica, Relazione general (1971 and 1972) 
Table III.2 - Italy: Price developments 1952-1968, annual percentage increases

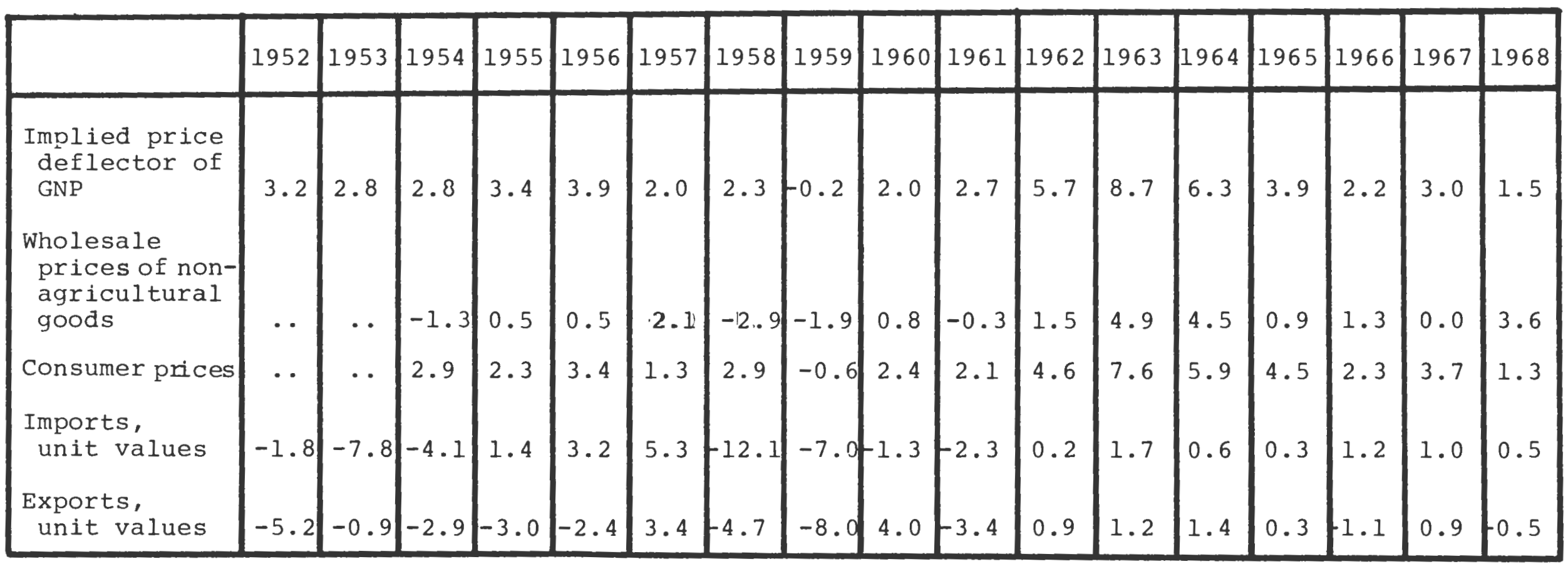

Sources: ISTAT; for 1972, Bank of Italy, Relazione Annuale. 
Table III.3 - Italy: Percentage contribution to expansion of gross domestic product in each period.

\begin{tabular}{|c|c|c|c|}
\hline & $1950-62$ & $1950-55$ & $1955-62$ \\
\hline $\begin{array}{l}\text { Total factor input } \\
\text { Labor } \\
\text { Capital } \\
\text { Output per unit of input } \\
\text { Advances in knowledge } 1 \\
\text { Changes in the lag of application of knowledge } \\
\text { Improved allocation of resources } \\
\text { of which: } \\
\text { Economies of scale } \\
\text { Total }\end{array}$ & $\begin{array}{r}28 \\
16 \\
12 \\
72 \\
13 \\
15 \\
24 \\
17 \\
21 \\
100\end{array}$ & $\begin{array}{c}31 \\
22 \\
9 \\
69 \\
12 \\
22 \\
19 \\
14 \\
16 \\
100\end{array}$ & $\begin{array}{l}26 \\
12 \\
14 \\
74 \\
13 \\
9 \\
28 \\
20 \\
24 \\
100\end{array}$ \\
\hline
\end{tabular}

1. Advances in technological and managerial knowledge, including business organization.

Sources: E. F. Denison, Why growth rates differ (Brookings Institution, Washington, D.C.). 
the shift of labor away from low-groductivity sectors (in particular, agriculture) to high-productivity sectcrs, and by enabling workers' wages to be maintained at low levels, relative to the rest of Europe, because of the weak targainirg position of trade unions due to widespread unemployment.

In 1963, the Italian economy experianced an inflationary period Eoliowed by a sharp recession which lasted until 1965. This situation was triggered by sharp wage increases forced upon the industry by the trade unions (see Table III-4). Lakor had its first opportunity to demand substantial wage increases in 1962 when full employment, and even shortages in scme types of skilled labor, was taking place in the industrial certers of the North. However, unemploymert and underemployment weIE still considerable in other regions and in low-paid, low-productivity sectors, such as agriculture, retail commerce and public administration. Init labor costs in manufacturing, which had been increasing at a rate of $1.2 \%$ in 1961, rose to $5.3 \%$ in 1962 and to $15 \%$ in 1963, dramatically reversing the trend observed during the 1950's, when they declined or the average (see Table III-4). Gross fixed-capita formation, which had been approximately $12 \%$ in 1960 and 1961. lost two percentage points in each one of the following years and declined sharply in 1964 and 1965 by $-6.4 \%$ and $-8.6 \%$, respectively (see Table III-1).

As a conseguence of wage increases, corsumer expenditures rose by $9 \%$ in 1963, compared with an average annual rate of increase of 5\% during 1955-62 (see Table III-2). Moreover, the rapid growth in personal income changed the compcsition of private consumption towar 3 high-quality foods, household durables and motor vehicles. 
Table III.4 - Italy: Output, employment, productivity, wages, unit labor costs, and profits in manufacturing, 1954-1968, annual percentage increase

\begin{tabular}{|c|c|c|c|c|c|c|c|c|c|}
\hline & $\begin{array}{l}1954-61 \\
\text { average }\end{array}$ & 1961 & 1962 & 1963 & 1964 & 1965 & 1966 & 1967 & 1968 \\
\hline $\begin{array}{l}\text { Output } \\
\text { Employment } \\
\text { Hours worked } \\
\text { Output per man } \\
\text { Output per man-hour } \\
\text { Wage rates } 2 \\
\text { Hourly earnings } \\
\text { Unit labor cost } \\
\text { Unit profits? } \\
\text { Gross profit ratio } 4 \\
\text { Non-agricultural wholesale prices }\end{array}$ & $\begin{array}{r}8.0 \\
2.1 \\
2.1 \\
6.0 \\
5.7 \\
4.5 \\
4.9 \\
-0.3 \\
-1.0 \\
45.1 \\
-0.2\end{array}$ & $\begin{array}{r}10.3 \\
4.8 \\
3.8 \\
5.2 \\
6.3 \\
4.4 \\
7.0 \\
1.2 \\
2.1 \\
41.8 \\
-0.2\end{array}$ & $\begin{array}{r}10.7 \\
2.5 \\
-0.3 \\
8.0 \\
11.1 \\
10.7 \\
15.3 \\
5.3 \\
-8.7 \\
38.6 \\
1.4\end{array}$ & $\begin{array}{r}6.5 \\
2.0 \\
2.3 \\
4.4 \\
4.1 \\
14.7 \\
16.8 \\
14.5 \\
-9.1 \\
34.8 \\
4.9\end{array}$ & $\begin{array}{r}1.3 \\
-0.2 \\
-4.4 \\
1.5 \\
6.4 \\
14.0 \\
11.1 \\
5.2 \\
4.0 \\
34.7 \\
4.4\end{array}$ & $\begin{array}{r}5.2 \\
-2.6 \\
-5.4 \\
8.0 \\
10.8 \\
8.5 \\
7.4 \\
-3.4 \\
13.8 \\
37.2 \\
0.9\end{array}$ & $\begin{array}{r}9.2 \\
0.6 \\
3.6 \\
8.5 \\
5.4 \\
3.9 \\
3.9 \\
-2.0 \\
10.9 \\
39.0 \\
1.3\end{array}$ & $\begin{array}{r}9.9 \\
3.6 \\
4.1 \\
6.1 \\
5.6 \\
5.5 \\
6.2 \\
0.4 \\
-8.7 \\
36.5 \\
0.0\end{array}$ & $\begin{array}{r}9.3 \\
1.0 \\
0.7 \\
8.3 \\
8.6 \\
3.6 \\
4.5 \\
-0.1 \\
5.4 \\
36.6 \\
0.0\end{array}$ \\
\hline
\end{tabular}

1. Value added in manufacturing

2. The base of the index was changed in 1966.

3. Gross profits per unit of output.

4. Value added minus compensation of employees as a ratio of value added-actual ratios, not annual percentage increases.

Sources: ISTAT, and data supplied by the Bank of Italy. 
The increase in consumption began affecting ingcrts in 1962 and the balance of fayments evolved from a balance of 551 million in 1961 a nd 51 million in 1962, to a afficit of 1,252 million in 1963 (see Table III-5).

By 1964, the decline of productive investments observed in the precedirg years, began to be felt by reluced employment and the rate of wage growth and, consequently, reluced consumption levels. on the other hand, the government had initiated deflaticnary policies by crerall monetary restraint. the use of fiscal measures, suci as raising taxes on a tomobiles and gasoline, and of all turnover rates, and by carrying out shcck imforts of butter and meat to be sold at government-controlled frices. In adition, to cover the loss of international reserves is 1963, credit facilities of 1 billion were obtained from the U.S.A. and hestern European central banks, and a credit of 225 million was received from the I.M.F. at the same time, due to a booming demand in other European countries (see Fig. III-1), the rate of exports increase accelerated from $6.9 \%$ in 1963 to $11.6 \%$ in 1954. These factors all contributed to an iuprovement of the overall economic situation, and, by the beqinning of 1965, the recession bad reached its turning-point. A four year period of relatively rapid exparsicn followed, but it took these four years to return to the fixed investment levels of 1963. During 1965-69, it might have appeared that the Italian economy was cormalizing, but, in tact, the recession of 1963-64 initiated a phase of serious diffictities that have since recurred in Italian econcmic life. 
Table III.5 - Italy: the balance of payments 1960-1968, million dollars

\begin{tabular}{|c|c|c|c|c|c|c|c|c|c|}
\hline & 1960 & 1961 & 1962 & 1963 & 1964 & 1965 & 1966 & 1967 & 1968 \\
\hline $\begin{array}{l}\text { Exports (FOB) } \\
\text { Imports (FOB) } \\
\text { Trade balance } \\
\text { Capital movements } \\
\text { Overall balance on nonmonetary } \\
\text { transaction }\end{array}$ & $\begin{array}{r}3,570 \\
4,216 \\
-646 \\
73 \\
437\end{array}$ & $\begin{array}{r}4,101 \\
4,679 \\
-578 \\
187 \\
551\end{array}$ & $\begin{array}{r}4,590 \\
5,505 \\
-915 \\
-309 \\
51\end{array}$ & $\begin{array}{r}4,974 \\
6,877 \\
-1,093 \\
-485 \\
-1,252\end{array}$ & $\begin{array}{r}5,863 \\
6,503 \\
-645 \\
110 \\
774\end{array}$ & $\begin{array}{r}7,104 \\
6,458 \\
646 \\
-455 \\
1,594\end{array}$ & $\begin{array}{c}7,929 \\
7,595 \\
334 \\
-1,277 \\
696\end{array}$ & $\begin{array}{r}8,605 \\
8,626 \\
-21 \\
-1,023 \\
324\end{array}$ & $\begin{array}{l}10,098 \\
9,050 \\
1,048 \\
-1,691 \\
627\end{array}$ \\
\hline $\begin{array}{l}\text { Foreign reserves, end of period. } \\
\text { Official reserves: } \\
\quad \text { Gold } \\
\quad \text { Convertible currencies } \\
\text { IFM position } \\
\text { Total Official }{ }^{2} \\
\text { Commercial banks: } \\
\quad \text { iNet foreign position }\end{array}$ & $\begin{array}{c}2,203 \\
876 \\
- \\
3,080 \\
-135\end{array}$ & $\begin{array}{c}2,225 \\
1,194 \\
243 \\
3,749 \\
-174\end{array}$ & $\begin{array}{c}2,243 \\
1,196 \\
203 \\
3,804 \\
-605\end{array}$ & $\begin{array}{c}2,343 \\
837 \\
226 \\
3,395 \\
-1,254\end{array}$ & $\begin{array}{c}2,107 \\
802 \\
141 \\
3,756 \\
-812\end{array}$ & $\begin{array}{c}2,404 \\
1,462 \\
479 \\
4,564 \\
-178\end{array}$ & $\begin{array}{c}2,414 \\
1,288 \\
885 \\
4,679 \\
230\end{array}$ & $\begin{array}{c}2,400 \\
1,419 \\
842 \\
5,238 \\
35\end{array}$ & $\begin{array}{c}2,923 \\
958 \\
894 \\
4,878 \\
723\end{array}$ \\
\hline
\end{tabular}

1. The IMF position includes credits granted on a multilateral basis previously recorded under other items.

2. Excluding medium- and long-term assets of the monetary authorities.

Source: Bank of Italy. 
Despite prcyress, especially in the feriod 1951-1963, the GNP per capita, the share of industry in tine grcss domestic product (GDP). the frivate consumption per capita, ard the share of national income investea in machinery and equipaert tave stayed considerabiy below the levels observed ir other advanced industrial countries. It is often emphasized in the literature that many of the Itaiian economic problems result from structural imbalances and distortions described by the term "dualism". In the words of podbieiski.

"These manifest themselves in disparities between technologicaily progressive, competitive, export-oriented and large-scale industries, on the one hand, and backyard, inefficient, traditional and medium sized industries, on the other: between a rafid growth of private consumption and a nighly inadequate level and sicw advance of collective consumption; betwe $\in$ n shortages of skilled workers in some areas and tine persisterce of large-scale under-utilization of labour rescrces in others; between excessive urbanization and congestion and the abandonment of rural regions.

All these aspects of an ecoromic and social 'dualism' appear in even sharper contrast in the development gap between Centre-North and the South ccuntry." (podbielski, 1974,pp, 2-3)

The historical basis for this "dualism" was explained in the historic overview earlier in this wcrk. The point of interest now is that the liberal policies of the recovery period following the war set the stage tor iuture eccnomic development based upon the forces of the "free market", without establishing planning institutions and instruments that would correct these structural imbalances. 


\subsection{ECOHOLIC LEGISLATION}

The general guidelines for the Italian econcmy are primarily dictated by the constitution, which was writter by Christian Democrats, sociaists and communists ir 1948. It establishes a compromise between the traditional liberal conception of civil and property rights, and the need for improvement of social conditions. The constitution authorizes certain cirect and indirect governmental intervention in the economy. Direct intervention includes governmental ownership and operation of enterprises, through special laws or ordinary rules. There are three types of governmentally owned agencies: i) the autonomous agercies, organs of Government ministeries: ii) the agencies owned and managed by state corporations, regulated by special laws and under government control; and, iii) the stock corporations, partially cuned by the state.

In 1967, a general economic plan was developed by the Ministery of the Budget and Economic Plannirg, for the first time, and was approved by the government. This economic plan is defined as the "Iramework of economic. financial and social pciicies of the Government and of all public investments". The plan is committed to: i) developing social services and institutions in areas related to education, housing, health, sccial security and scientific research; ii) providing equality of agricultural, industrial, professional and commercial incomes; ard, iii) reducing the disparity between developed and underaevelofed regions in the country. The plan defines public investments in fields of state responsibility and provides guidelines for agricultural, industrial and commercial 
development. Although it establishes compulscry rules that apply only to pubic agencies, it is expected that governmental bodies use this plan as a guideline for reguiation of private enterprise. primarily through taxation and credit measures.

Urban planning is almost nonexistent ir Italy. However, in 1967. an amendment to a 1947 on urban planning law mandated that muicipalities adopt compulsory plans. In particular, this provision allows municipalities to acquire zand acccading to plans which are developed for low-income housing.

In the 1950's, land reform programs authorized the expropriation of under-utilized land and its delivery to unemployed farmers. Iater, in 1961, a Five Year Plan fcr the Development of Agriculture, also known as the "Green Plan", was eracted to develop and stimulate the economic and social situation of the agricultural sector. Contrary to the land reform prçrams of the 1950's, the "Green Plan" approaches comprehensive eccnomic development.

Price control was initially adcptedly in 1936. During horld Har II. the prices of goods were actually Erozen. By 1944. the Interministerial committee on prices (CIE) was created to regulate: i) price of products, both domestic and foreign; ii) supply and distribution of basic Foreign commodities; and, isil interprovincial trade. The cIP exercised tight controi during and immediately following forld waI II, but it has since gradualiy restricted its intervention to essential commodities and services, public utilities and monopclistic or oligopolistic rarket actions. 
Although the 1948 Constituticr. provides for nationalization of the public service sector, most of tre putiic utilities had been nationalized prior to the constitution. The only utilities to be nationalized atter 1948 were the electrical power generation and distributicn enterprises, which were nationalized in 1962. In this context. "nationalization" does nct denote state cwnersip and management, cut, rather, direct sufervision of an enterprise. This system of state control is called "frarchise". It has a limited duration, which can be renewed, and its terms are stipulated by a contract.

The nationalized enterprises car be divided into fiscal monopolies (such as the sale of tobacco, matches and salt, and the operation of lotteries), and into public services (postal facilities, teleqraph, telephones, radio, televisior, railroads). The nationalization of the enterprises in the first group was carried out witn the cbjective of gaining putlic control of those high profit activities. The nationalization of those in the second group was the standardization of important gublic services. The most important state property-holaing companies in Italy are the Institute per la Reccnstruzione Industriale (IRI) and the Entenazionale Idrocarburis (ENI), created in 1933 ard 1953, respectively. The effect of the IEI in the Italian econcmy is substantial, as it controls a large number of enterprises, but, since its aim is primarily to aid "sick" industries, its profits are Iow. The ENI, created to perform a dynamic role in the Italian ecoromy and concentrated in specific sectors, is the more productive. 
The Italian banking system was completely reformed in 1938, as a consequence of the deficient monetary policies applied in 1926 by the Italian Discount Bank (Banca Italiara di Sconto). The monetary and banking policies have, since then, been defined by an Interministerial committee for the protection of Savings and the Regulation of credit, and implemented by the Eank of Italy (Banca di Italia). The Bank of Italy is responsible for the: issuing of currency, setting of discount rates, keefing the rreasury provincial reserves, issuing licenses for the creation of new banks or new branches of existing banks, exercising supervision and control over al1 other banks. The Ministery of the Treasury exercises regulative power over the banks, upon suggestions ot the Bank of Italy, by imposing sanctions and penalties for violations of the established rules.

In Italy, direct taxes include income taxes on land, buildings, movable wealth and aqriculture. In addition, a progressive complementary tax is applied to individuals and a company tax is applied to enterprises. The indirect taxes include: turnover tax lievied on prices of goods and services, at a rate or 4\%), registration tax llevied on the total value cf contracts, deeds and bills of sale executed is National territcry, at rates varying from $1 \%$ to 7.5\%), profits from fiscal monogclies. The indirect tax revenues account for $70 \%$ of the total revenues. Direct taxes are considerably inigh, but they provide cnly a Iodest share of the total tax returns, which suggests signikicant tax evasicn. 
Several social security programs coveriru or-the-job accidents, occupational diseases and unemplcyuent exist, and are compulsory for employers and employees, who are both required to contribute. Three main agencies are responsible for these prcgrams: InPS lunemployment, tuberculosis, insurance and family allowances, old age, death and disability pensions), INAM (nonoccupational and pensioner's health insurance, including aterrity benefits). INAIL (women compensation, occupational health risks, non-occupational accident benefits). 


\section{ChapteI IV}

\section{DEVELOPMENT OP THE SOCIAL INDICATORS MODEL}

Most of the studies which investigate the impact of internal and external folicies on the quality cf life in a country use an exclusively economically oriented apprcaci. The underkying assumption of this apfroach, that the quality of life of a population is directly related to the wealth of the nation, has been challenged by social sciertists. A growing awareness of the tiases and limitations invclved in a strictly econcmic approacr has created the need to determine a mechanism to assess directly the general quality of lice in a scciety.

In fact, the belief that high income levels do not necessarily imply the satisfaction of the $n \in E \bar{c} s$ and aspiraticns of a population contributed to the awareness of the insufficiency of the economic approach and created the basis fcr the development of tise "social Indicator Movement" and the closely associated concern with the concept of "Quality of Life".

The development of an analytical model to assess the impact of the EEC membership on the quality of life in Italy, which is described in the present study, is governed ky the assumption that societal well-being includes sccial as well as economic concerns. 


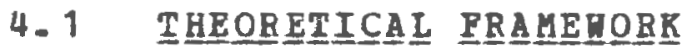

The theoretical framework underlying the present work involves two components: the concept of "Quality of life" and tne general structure of social inäicator models.

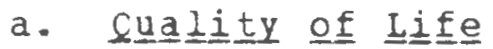

Several approaches have been froposed tc described the concept of "Quality of life". Perhaps the two most common are one which empiasizes the individual's perception of being fleased (happy or satisfied) with the characteristics of his/her life, and one which regards quality of life as the totality of observable conditions in which peofle live. The frcponents of the first approach emphasize the use of individual responses tc guestionraires, content analysis and discussions, all highly subjective measurement tools, and contend tinat more important than the cbserved fhysical facts about the life conditions of the individual is the way he/she perceives them. The proponents of the second apprcach question the reliability and relevance of the information obtained from declarations of the indiviouals concerned, and emphasize the extent to which the answers to such Inquiries can be affected, or even determined, by the researcher conducting the inquiry. Therefore, they favor the use of direct observation of objective facts about life conditions.

It can be arqued that the two views presented above should both be incorpcrated in "Quality of Iife" studies, but the question of the proper use of subjective and objective indicators has not received consensus among researchers. Some methodological problems 
are involved in this question (UNESCO,1974): i) experimentally observea correlatious between objective and subjective indicators are gereraliy weak; ii) individuals who are more critical of their quality of life are often those whc, objectiveiy, have greater resources, such as education and inccme; iil emirical research has determined that judgement of satisfaction is affected by the consideration of reference groups; iv) an irdividual's dissatisfaction with an element of quality of life tends to elevate the comparative importance cf that element in the cverall personal judgement, and, accordingly, elements that are well provided for in a society, so as to be taken for granted, are attenuated in the individual's perception of the quality of life; and, v) overall high or low levels of satisfaction of individuals with their quality of life have been observed to influence their perceptions of each of the specific elements of their life quality. The sccpe of the present work involves the quality of life of the population of an entire country, rather than an analysis of inaivicual psycholoyical attitudes. For this reascn, and because there exist no definitive data regarding how life conjitions are perceived by individuals in Italy and how to classify ard quantify these Eerceptions, the present study is based solely on objective data regarding observable life conditions that are generaliy accepted as important factors in guality of life.

Tine abcve considerations taken into account. "Quality of Life" is explored, in the present study by comprefensive criterla defined in terms of the degree of fulfiliment of the casic human needs associated wh the human life cycle, and the satisfaction of general 
human expectations which may not be basic needs, but are, in general, considered important life conditions for a population. The basic kuman needs are defined in $r \in l a t i o n$ to the fcllowing elements: nutrition, shelter, health, safety and leisure. Assessing the satisfaction of general human exfectations is far more difficult. Culture-dependent aspirations of a population must be identified, yetreliable empirical studies on individua expectations are presently unavailable. For the purfcse of the present study, the folLowing human expectations are considered: education, communication and cuiture. These were identified by the authcr as major general human expectations, in terms of values of present-day western civilization.

The twc main cateqories mentiored above, basic human needs and general human expectations, are the determinants for the development of the social indicator model in the present study.

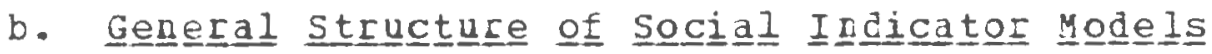

The anaiptical model developed for this study is organized according to the conceptual framewcrk provided by land and spilerman (1975) for the general structure cf social indicator rodels. They suggest that social indicators be organized intc two broad categories: exogenous variables and exdogenous variables. The former refers to factors determined outside the social system model (inputs). and the latter identify factors determined by the model (outputs). Each of these tro grcups is further divided in another two: policy instrument descriptive indicators and nonmanipulable descriptive indicators, For tine input variables, and output de- 
scriptive indicators and side-effect cescriptive indicators, for the output variables. These four groups of indicators are interrelated through the social system mcdel, which is associated with internal variables characterized by the so-called analytical indicators.

The different groups of indicators considered above can be defined as fcllows:

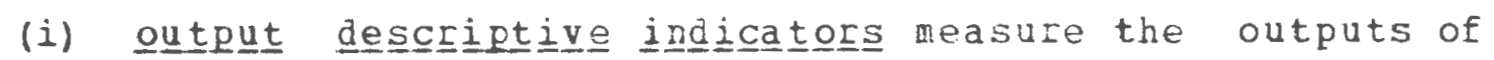
the system model wich are most cirectiy associated with the assessment of the social situation urder study;

(ii) policy instrument indicatongs refer to inputs to the model which are the result of direct policy actions

(iii) nonmanipula witi inputs to the model and are not subject to direct policy actions:

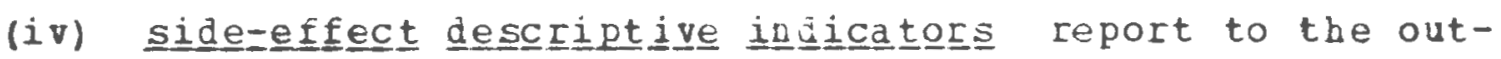
puts of the social system model which are not of direct concern for the assessment of the social situation under study, but are directIy $r \in l a t \in d$ to it; and.

(v) anna Iytic indicator $\underline{\text { ing }}$ associated with the social system model interactions.

The comprehensive approach deferded by land and spilerman has the advantage of providing a classification scheme to group social indicators in a rational ard logical way. It provides an organizational framework which puts into ferspective the relationships between the different components of sccial indicators. 


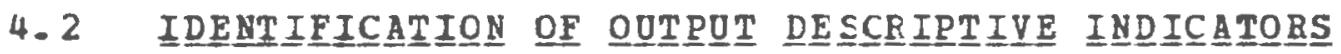

output descriptive indicators are the nost infortant indicators because they involve the variables directly related to measuring the quality of life. Accordingly, the number of indicators considered and their description is much more detailed than for the other groups of indicators.

As explained in the preceding section, the major hypothesis used in the development of social indicators for the guality of life is that the guality of life is directly related to the degree of satisfaction of the basic human netcs ard the fulfillment of general human expectations.

The basic human needs were classified above as: nutrition, shelter, health, safety and leisure. The satisfaction of these needs may be evaluated by the indicators reported in table IV-1. In an anaiysis ct nutrition both the quantity and the quality of the products consumed are examined and determined by the consumption levels of several food products ard cf their proteir and calorie contents. The adequacy of shelter aly be evaluated by the number of available tousing urits per capita, the percentaje or bousing units not occupied, the number of structures used for shelter which are not proper tousing, the number cf housing units with services or facilities suct as sewage, water, electricity, bathroom, kitchen, and tue demand for shelter from frivate and public social services. The quality of treaith is influenced by the quantity and the quality of available bealth services, and by environmental factors or factors related to the style of life. Quality of health can also be 

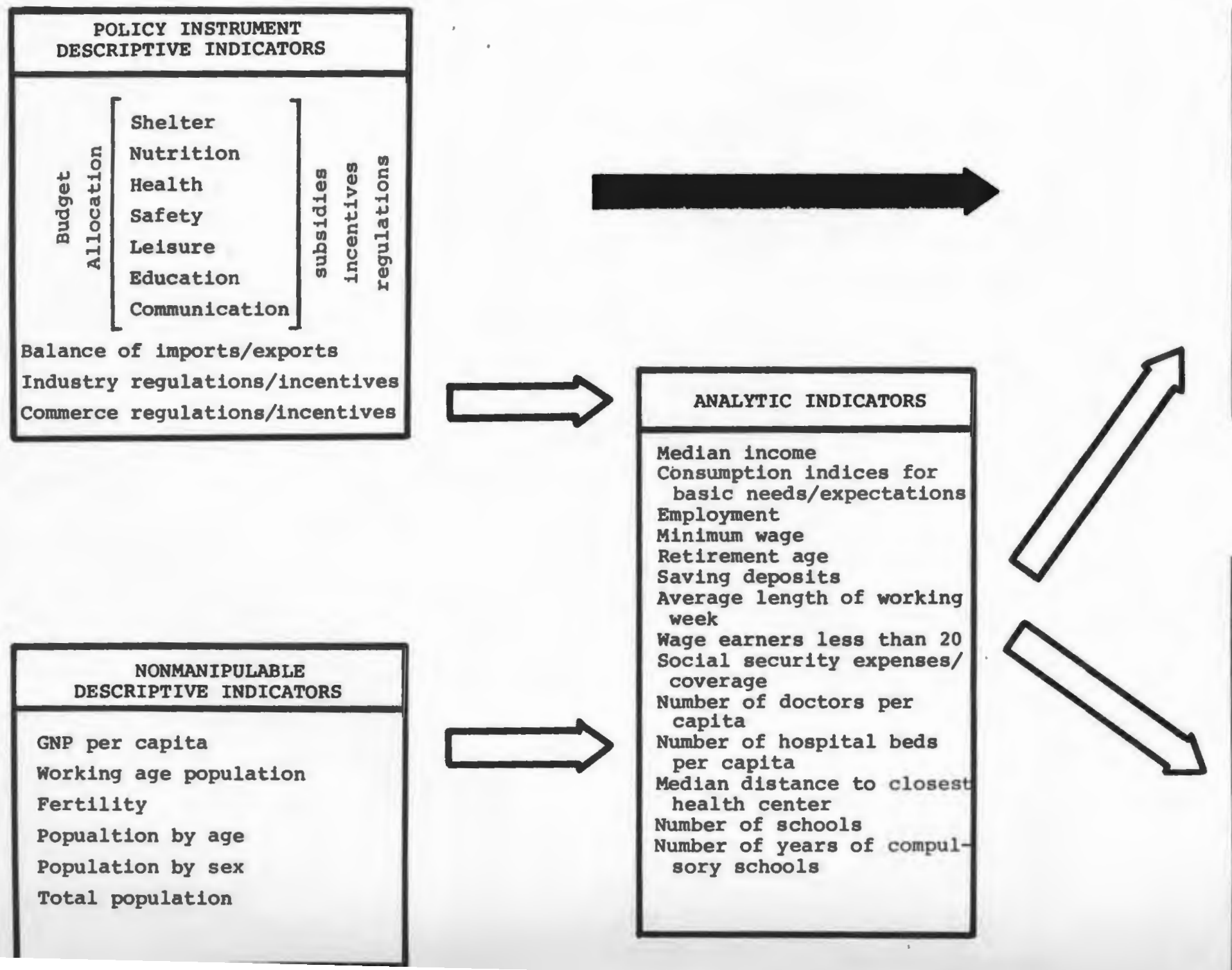

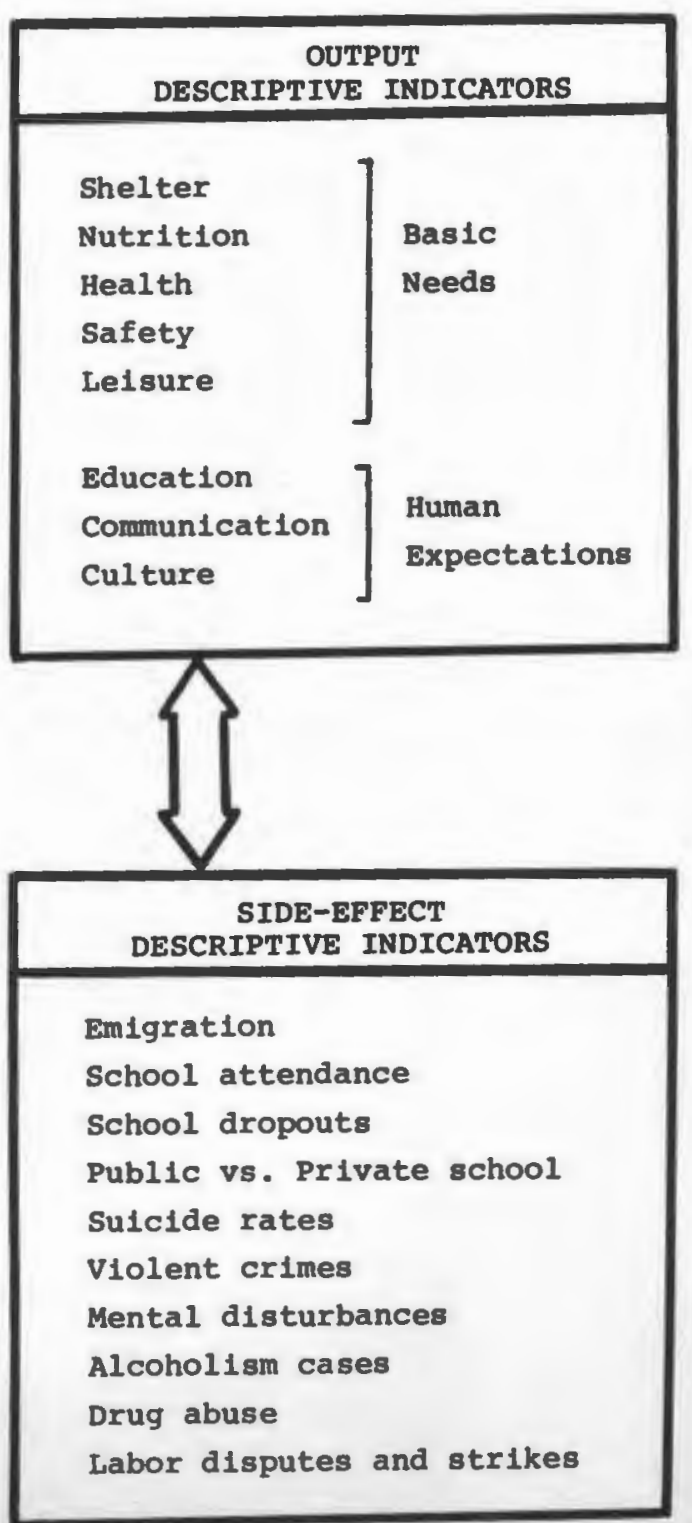


Table IV.I - Output Descriptive Indicators (Basic Human Needs)

AREA OF SOCIAI CONCERN

Nutrition

Shelter

Health

Safety

Leisure

\section{INDICATOR}

Meat consumption per capita

Fish

Milk

Eggs

Cheese

Sugar

Fruit

Vegetables "

Cereals "

Potato

Animal protein consumption per capita

Vegetal protein

Animal calories

Vegetal calories

"

"

"

Demand for food from social assistance service

Number of housing units per person Number of rooms per housing units Percent of occupied housin units Percent of other type of shelter relative to total housing units

Services and facilities available in housing units

Demand for shelter from social assistance services

Mean age of death

Mortality rate

Infant mortality rate

Incidence of epidemic diseases

" " " circulatory "

Traffic accidents leading to death Number of homicides

Number of other (than traffic and homicides) accidents leading to death Number of robberies reported to the police

Total time available for leisure Recreational area available Use of leisure time 
evaluated by analyzing the mean age of jeath, mortality rates, the incidence of certain epidemic, circulatory and respiratory diseases. Safety can be accessea by examining the incidence of accidents and crimes, and, to a certain extent, the levels of environmental pollution. The satisfaction of leisure needs depends on the number, size, availability and characteristics of leisure facilities, and on the total amount of time available for leisure accompanied by statistical information on the use of that leisure time.

The general human expectations considered above are: education, commuicaticn ard culture. The fulfillment cf these expectations can be evaluated by the indicators listed in Table IV-2. Education can be assessed by an analysis of illiteracy and encollment rates and the number of students per $t \in a c h e r$ in the several educational qrades. Communicaticn involves the movement of people and the indirect means oi communication at long distance, either written or spoken. These can be enquired through information on road and railway traficic (both the number cf vehicles and the length of road or railway), information on the use of available transportation. the number of telephones per capita ald the number of phone calls, letters and telegrams per capita. The adecuacy cf cultural opportunities is determined by the availability and usage of books, art museums and galleries, concert anc theater gerformances. 
Table IV.2 - Output Desriptive Indicators (Human Expectations)

\begin{tabular}{|c|c|}
\hline AREA OF SOCIAL CONCERN & INDICATOR \\
\hline Education & $\begin{array}{l}\text { Percent of illeterates } \\
\text { Percent of school age population } \\
\text { enrolled in different grade groups } \\
\text { Number of students per teacher in } \\
\text { different grades }\end{array}$ \\
\hline Communication & $\begin{array}{l}\text { Number of passenger cars } \\
\text { Number of commercial vehicles } \\
\text { Length of motorway } \\
\text { Length of railway } \\
\text { Railway passenger traffic } \\
\text { Number of telephones per capita } \\
\text { Number of telephone calls per capita } \\
\text { Number of letters per habitant } \\
\text { Number of telegrams per habitant }\end{array}$ \\
\hline Culture & $\begin{array}{l}\text { Number and use of published books } \\
\text { Number and use of public libraries } \\
\text { Number and diversity of theater } \\
\text { performances } \\
\text { Number of theater admissions } \\
\text { Number of visits to museums } \\
\text { Number of visits to art galleries } \\
\text { Nulber of visits to monuments }\end{array}$ \\
\hline
\end{tabular}




\subsection{IDENTIFICATION DE SIDE-EEEECT DESCEIPTIVE IEDICA TOERS}

Siàe-effect descriptive indicators are outputs of the social system model which are not directly relatea to the determinants of the quality of life, but are associated indirect indicators. They provide an indirect measure of the satisfaction of the population with the life conditions in the nation. The following variables are considered in this group: erigration, anti-social benavior (suicide rates, violert crimes, mental disturbances, alcoholism and drug addiction), labor disputes and strikes, school attendance rates, schccl dropout rates, attendance of frivate vs. public education.

\subsection{IDENTIEICATIOQN OP POLIICY IN}

The policy actions which influence the guality of life in a nation are ultimately taken at the governmental level. The primary determinant of governmental policies is the allocation of the country resources to the different areas of social concern, as assigned in the national budget. consequently, the srare of the total resources allocated to each one of the basic humar needs and expectations provides primary poiicy instrument indicators for the quality of life, as well as the regulatory/incentivation measures taken by the government. other policy instrument indicators are: the balance of imports/exports, industry regulation/incentivation measures, and comerce regulation/incertivation. These are the major means available to the goverliment for influencing the quality of Iife its citizens through policy Ifasures. 


\subsection{IDEENTIPICATION OF NON}

The infuts to the social system model which describe external influences on the guality of life which are not directly subjected to policy actions involve: Gross National product (GNP) per capita, Gross Domestic Product (GDP) per capita, and demographic characteristics such as total population, population by sex and age. urbar añ nonurban population, stare of pofulation in working age, fertility. These indicators prcvide informaticn on the general prorile cf the country and are used as a secondary information base.

\subsection{HODEL FOR SOCIAL SYSTEE. IDEFNTIFICCATION OP

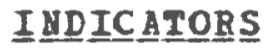

The interactions between the inputs and the outputs of the social system model, which were identified in the preceding sections, are giver in diagramatic fcrm ir ig. 4-1.

Budget allocations and incentives/regulations directly infiuence the fuifillment of the associated basic needs and human expectations. other basic reeds and humar expectaticns are also directly influenced: policies on both shelter and nutrition influence the quality of health: policies on saftey influence comunication: policies on leisure influence health, education, communication and culture: and the policies cn comurication irfiuence safety, leisure, culture and shelter. The policy instrument variables are also directly related to certain r.crmanipulabie variables, such as GNP and GDP. 
The side-effect descriptive variables influence, in a direct way. some of the output descriptive variables: school attendance, school dropcuts and the attendance of pivate vs. public schools are relatea to education; anti-social tehavior is related to health: violent crimes are reiated to safety: labor disputes and strikes provide information on the satisfaction of all needs and expectaticns.

Certain analytic variables, related to the interactions of the model inputs and outputs, are explicitly mentioned below due to their particular importance in connection with the objective of this present study. These variatles aze: median income, share of income allocated to each one of the identified basic needs and expectations, employment, minimum wage, reticement age, savings deposits, average iength of the working week, wage earners under 20 years oid, social security expenses and coverage, number of medical doctors per capita, number of hosfital teds per capita, median distance to clcsest hospital facility, number of schools at different levels, anà number oí years of ccapulsory educatior.

Relative to the direct interactions of these variables with inputs of the model, the following are the most imfortant: the median income and the consumption irdices for each one of the basic needs or expectations are determined by the irputs to the model. and determine, in a direct way, ali the outputs; employment, minimum wage, retirement age, savings deposits, and average length of working week are directly deternined by the policies on education, the values of GNP, and the size cf the working age population; the 
number of medical doctors and the number of hospital beds are directiy affected by the policies cI health ard education; the number of schools and the number of years ot compulsory education are inEluenced by the policies on education. On the other hand, the analytic variables influence the outfuts in the following direct ways: employment, meāian income and minimum wage determine emigration; rumber of medical doctors and number of hospital beds determine

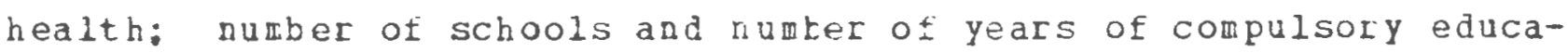
tion determine education; and social security expenses and covering influence the satisfaction of shelter, nutritional and health needs.

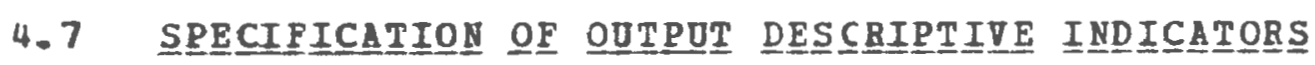

Since the output descriftive indicators are the most important for this analysis, they are described in detail in this tion. For each one, the concept represerted, its defirition, its purpose, its assumptions ard limitations are described.

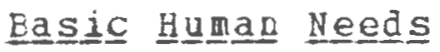

A. Nutrition

(i) Meat consumption fer cafita

$\begin{array}{llll}\text { (ii) Fish } & " & " & " \\ \text { (iii) Milk } & " & " & " \\ \text { (iv) Egqs } & " & " & " \\ \text { (v) Cheese } & " & n & "\end{array}$




\begin{tabular}{|c|c|c|c|c|c|c|}
\hline (vii) & Fruit & $"$ & $" 1$ & 11 & & \\
\hline (viii) & Vegetab & les" & "1 & 11 & & \\
\hline$(i x)$ & CereaIs & 11 & " & $"$ & & \\
\hline$(x)$ & petato & $n$ & 11 & $n$ & & \\
\hline$(x i)$ & Anima 1 & protein c & Consum & ion & per & capita \\
\hline (xii) & Vegeta 1 & protein & $" 1$ & & $n$ & $"$ \\
\hline (xiii) & Acimal & calories & $n$ & & "1 & $" 1$ \\
\hline$(x i y)$ & Vegeta 1 & calories & 11 & & $"$ & 11 \\
\hline
\end{tabular}

concept

Represented consumption of essentiai nutrients.

The

Measure Total weight (cr volume) consumed yearly divided by the total fcpulation, for each one of the products, exceft for calories consumption when it is the total number of calories yearly consumed divided by the total population.

Purfose To measure the adequacy of nutrients consumption.

Assumptions High values of these measures are positive indicators of the satisfaction of rutrition needs.

Limitations High consumpticns of the above nutrients does not necessarily mean a jetter diet, though that still provides some indication on diet quality. 
( $X \nabla)$ Demand of food from social assistance services

\section{Concept}

Represented The impossibility of in.lividuals to account for their cwn food supply.

The

Mea sure

Total number of persons seeking food assistance divided by the total populaticn.

Purpose To measure the inability of individuals to provide for their cwn rutrition.

Assumftions The population not able to account for adequate rutrition seeks food supply from social assistance services. A decrease on the value of this indicator idertifies an imprcvement on the satisfaction of rutrition reeds.

Iimitations population seeking assistance is not a reliable measure of deprived population. Irrational aliocation of irdividual filancial resources is not accounted for. Indiviauals with financial resources to provide for their own nutrition may ask social assistance due to a deficient allocation of their resources, e.g., drug addicts. 
B. Sheiter

(i) Number of housing units fer person

concept

Represented Number of building structures oficially qualifying as adequate for housirg.

The

Measure Total number of housing urits divided by the total population.

Purpose To measure the availabiitty cf housing in the market.

Assumptions High values of this variable are assumed to be desirable since they imply better opportunities for adequate hcusing conditions, less overcrowding of individual units and lower housing costs. Limitations The number of units availabie in the market is not necessarily a measure on the availability of adecuate housing. The guality of the housing units, their localization and affordability are not taken into consideration.

(ii) Number of rooms per housing unit

conceft

Represented size of the hoising units. 
The

Measure Total number of rooms in all housing units which could be possilly used as bedrooms (kitchens and bathroomis are not included) 3ivided by the total number of housing units.

Purfose To measure the adequacy in size of the available housing units.

Assumptions large values ct this indicatcr are considered positive for the quality of shelter. since they imply the possibility f relucing overcrowing. IImitations Does not necessarily measure the adequacy in size of housing units. These are only mean values for trie tctal housing units, without distinguishing toc small or too big housing units, and without corsidering the size of the families habiting them.

(iii) percent of occupied housing units

Concept

Represented Availability of unoccupied rousing units.

The

Measure Percentage of the total housing units which are occupied.

Pur fose To measure the availability of housing in the market.

Assumptions (as for (i))

Limitations (as for (i)) 
(iv) percent of other type of shelter reiative to total bousing inits

\section{Concept}

Represented Inadequate shelter being used.

The

Measure Percentage of structures that do not oficially qualify as adeguate tor housing, but are actual1y being occupied for that purpose, relative to the total number of structures oficially gualifying as adequate for housing.

Purpose To measure the share of structures inadequate for housing which are actually being used for this purpose.

Assumptions High values of this indicator are negative for the quality of rousing.

Iimitations Does not provide information on the comparative distribution of the quality of the structures involvad, and $c n$ the number of persons housed in such unappropriate shelter.

(v) Services and facilities availaile in housing units

Concept

Represerted The quality of bousing urits.

The

Measure

$$
\begin{aligned}
& \text { Percentage of housing urits with water supply. } \\
& \text { electricity sreply are sewage facilities over } \\
& \text { the total number of housing units. }
\end{aligned}
$$


Purfose

To measure the share of housing units meeting minimum quality standarcis and sanitary conditions.

Assumptions An increase in the value of this indicator is considered positive for the quality of shelter.

Iimitations The conditions used in the classification of houses with services and facilities may fail to be directly related to the guality of shelter. cultural and Educatioral constraints are not taken into consideratior. (groups of population exist who use faclities for unusual purposes,such as indccr gardens in the bathtub).

(vi) Demand of shelter from sccial assistance services

Concept

Represerted The impossibility of individuals to account for their own shelter.

The

Measure Total number cf persons seeking shelter assistance divided ly the totai population.

Purfose To measure the inability of individuals to provide for their cwin shelter.

Assumptions The populaticn unable of accourting for adeguate shelter seeks it from social assistance services. A decrease from the value of this indicator identifies an improvement on the satisfaction of nutrition need $s$. 
Linitations Population seeking assistance is not a reliable measure of the deprived population. Irrational of individual financial resources is not accounted for.

c. Health

(i) Mean age of death

Concept

Bepresented The longevity cf the population.

The

teasure tean age of death of individuals dying per year. purpose To measure the quality of health care and safety.

Assumptions an increase on the value of this indicator is related to better health conditions.

Limitations $A$ increase in the mean age of death may be achieved by increasing the number of people living in supervised and restricted medical situations, and it may be argueable that this vould be a significant imfrovement in the quality of health care. More iafortant, changes in the age composition of the fopulation are not taken into account and this affects the conclusions that can be drawn from this indicator (a disproportionate increase of young population may indirectly result in higher mean age of death. 


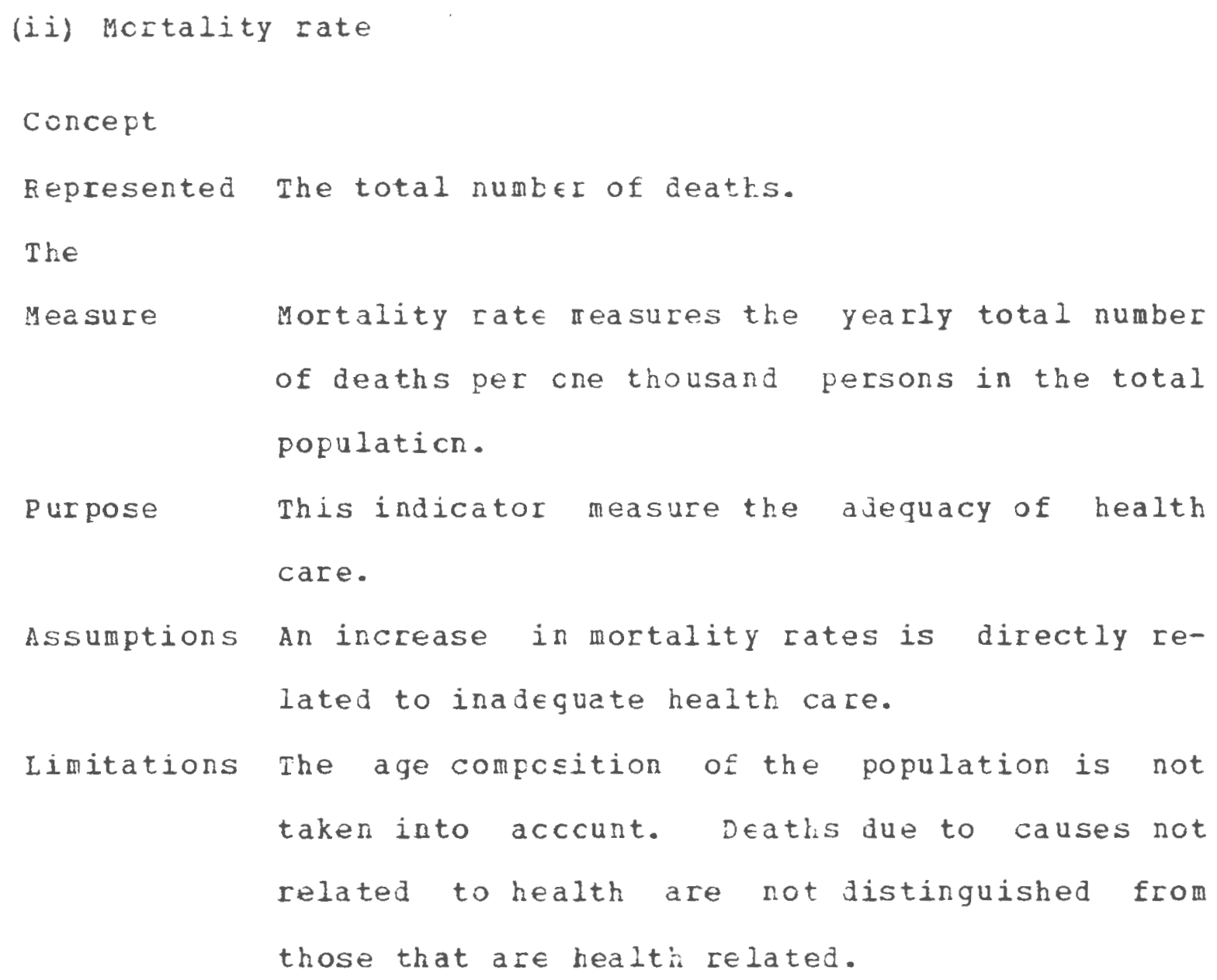




\begin{abstract}
Assumptions A decrease in the infant mortality rate is assumed directly associated to an increase in the quality of the health care conditions.

Limitations Deaths are not exclusively related to health conditions.
\end{abstract}

(iv) Incidence of epidemic diseases

$\begin{array}{cccc}\text { (v) } & " & " & \text { tumor } \\ (v i) & " & \text { " circulatory } \\ \text { (vii) } & " & \text { " respiratory }\end{array}$

Conceft

Represented Preventive health care for most frequent diseases.

The

Measure Number of hospitalized patients with the corresponding disease per one thousand habitants.

Purpose To evaluate preventive medicine.

Assumptions Lower values cf these varizbles are indicative of better health care.

Limitations The incidence $C I$ the disease is not completely related to the inadequacy of preventive health care. 
D. Safety

(i) Traffic accidents leading to death

Concept

Represented Lack of safety.

The

Hea sure

Total numer of gearly reported cases of traffic accidents involving deaths, per one nillion habitants.

purpose To measure inadequacy of transportation infrastructures and traffic safety.

Assumtions High values of these variable indicate bad safety conditions in traffic.

Limitations The comparative importance of the several accidents is not included in this measure.

(ii) Number of Honicides

Conce pt

Represented Lack of security against crime.

The

Measure Total nuaber of homicides yearly reported to the police per one million habitants.

purpose To assess safety of the environment.

Assumptions The increase in homicides is a threat against safety. 
Limitations homicides are erequently reiated to specific events and do not represent a direct threat to the overall safety of the population.

(iii) Numer of other (tinan traffic and iomicides) accidents leading to death

Coricept

Represented Lack of safety açainst accidental death.

Tire

Meásure

Total nuber of accidents leading to death, other than traffic accidents and romicides.

Purfose To assess safety of the environment.

Assumptions The increase of this indicator represents a threat against safety.

Iimitations The causes of tre reported accidents are not taken into acccunt in this indicator and. consequently, it is not possible to have a clear evaluation of the threat they represent to the safety of the crerall pofulation.

(iv) Number of robberies repcrted to the police

Concept

Represented Lack of security aqainst crime.

The

Measure Total number of yearly reported robberies.

Purpose To assess safty of the ervircnuent. 
Assumptions The increase ir criminal activity is a threat aqainst safety. Besides the possible dispossession of froperty. which afiects directly the individual who is robbed, other individuals fear to be victims cf crime ard, in trying to avoid being subjected to it, they limit their activities, interfering with tie fulfillment of their needs and aspirations.

Limitations subjective judcement is involved due to different perceptions of public safety. Besides, the comparative imfortance of the reported robberies is not taken into account.

E. Leisure

(i) Total time available for leisure

Concept

Represented The availability of time of each individual for activities cther thar work, transportation to and from work, meals and sleep.

The

Measure percentage of the total time available for activities other than work, transportation to and from work site, meals and sleep.

purfose Measures the individual availability of time for leisure. 
Assumptions quality of life is positively related to the availability of time for leisure.

Limitations Does not consider the opportunities to use leisure time in a gratizying way, and does not exclude the possitility of individuals using this time for other working activities.

(ii) Recreational area availatle

Ccncept

Represerted per capita availability of recreational space.

The

Measure Total area assigned to recreational activities divided by the total population.

Purpose To measure tife space available for recreation.

Assurfions This indicator measure recreational opportunities of the pofulation. An increase in its value is considered fositive for the quality of life.

Iiritations Does not take irto account factors like utilization rates, adequacy for recreational uses, accessibility, types of recreational facilities provided, iocation, size.

(iii) Use of leisure time

concept

Refresented Utilization of leisure time. 
The

Measure

Pur pose

Assumptions

Iimitations
Allocation of time available for leisure by activities actual1y performed.

To evaluate the adequacy of utilization of tine available for leisure.

The percent of time dedicated to recreational activities is assumed to be positive for the satisfaction of leisure needs.

Does not take into account the specific circumstances associated with the activity performed. certain individuals may feel more gratified by carrying out work assignments than by participating in recreational activities.

\section{Human Expectations}

A. Education

(i) Percent of illiterates

concept

Represented Share of the tctal populaticn deprived of education.

The

Heasure Percentage of illiterates in the total population over 6 years old.

purpose To measure the cpportunities for education. 
Assumpticns Decreases in this variable are assumed to be positive for the fulfillment of the population educational exfectations.

Limitations certain cases ct illiteracy may be unrelated to educatioral offcrtunties. Certain individuals may be physically handicapped or may have resused, by perscral choice, tc attend school.

(ii) Percent of school age fopulation enrclled in different qrade groups

Concept

Represented share of schccl age population enrolled in school.

The

Measure Total number of students enrclled in each grade group diviced by the total population of the corresponding age group.

Eurfose To measure the adequacy of educational opportunities.

Assurptions people not enrclled in the school were forced to be in that situation due to lack of opportunities.

Limitations Does not take into account the student population having cffortunitzes but not willing to stuajy due to other reasons, such as illness or mental disturbances. 
(iii) Number of students per teacher in the different grades

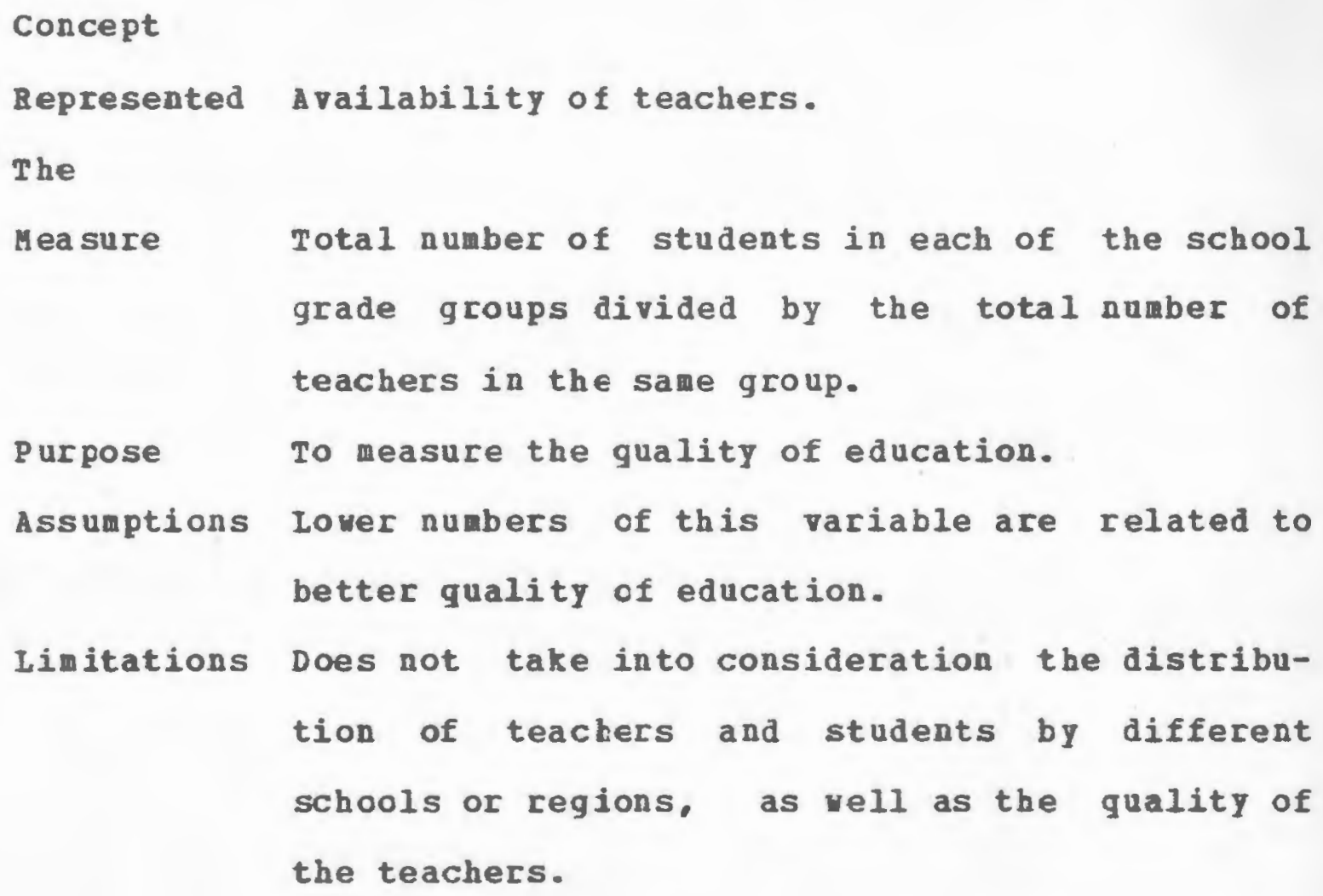

B. Communication

(i) Number of passenger cars

(ii) " " Commercial vehicles

Concept

Bepresented Sobility of the population by road transportation.

The

Heasure Total number cf vehicles by one million habitants. 
Purpose

To measure the opportunities for mobility by road transportation.

Assumptions The mobility cf the population increases vith the increase of the number of vehicles. Such an increase is considered positive for the quality of Iife.

Iimitations Does not take into account the quality of vehicles, the utilization rates, and the fact that certain individuals own more than one vehicle.

\section{(iii) length of motorvay}

(iv) " " Iailvay

Concept

Represented Existing transfortation infrastructures.

The

Measure

Total length of existing motoruay or railuay.

Purpose

To measure the wobility opportunities of the population.

assumptions The length of motorway and railvay reflect the mobility of the population. High values of this variable are assuned to be favorable for the quality of life of the population.

Iimitations Does not take into account rates of utilization, quality of transportation and adequacy of the communication network. 


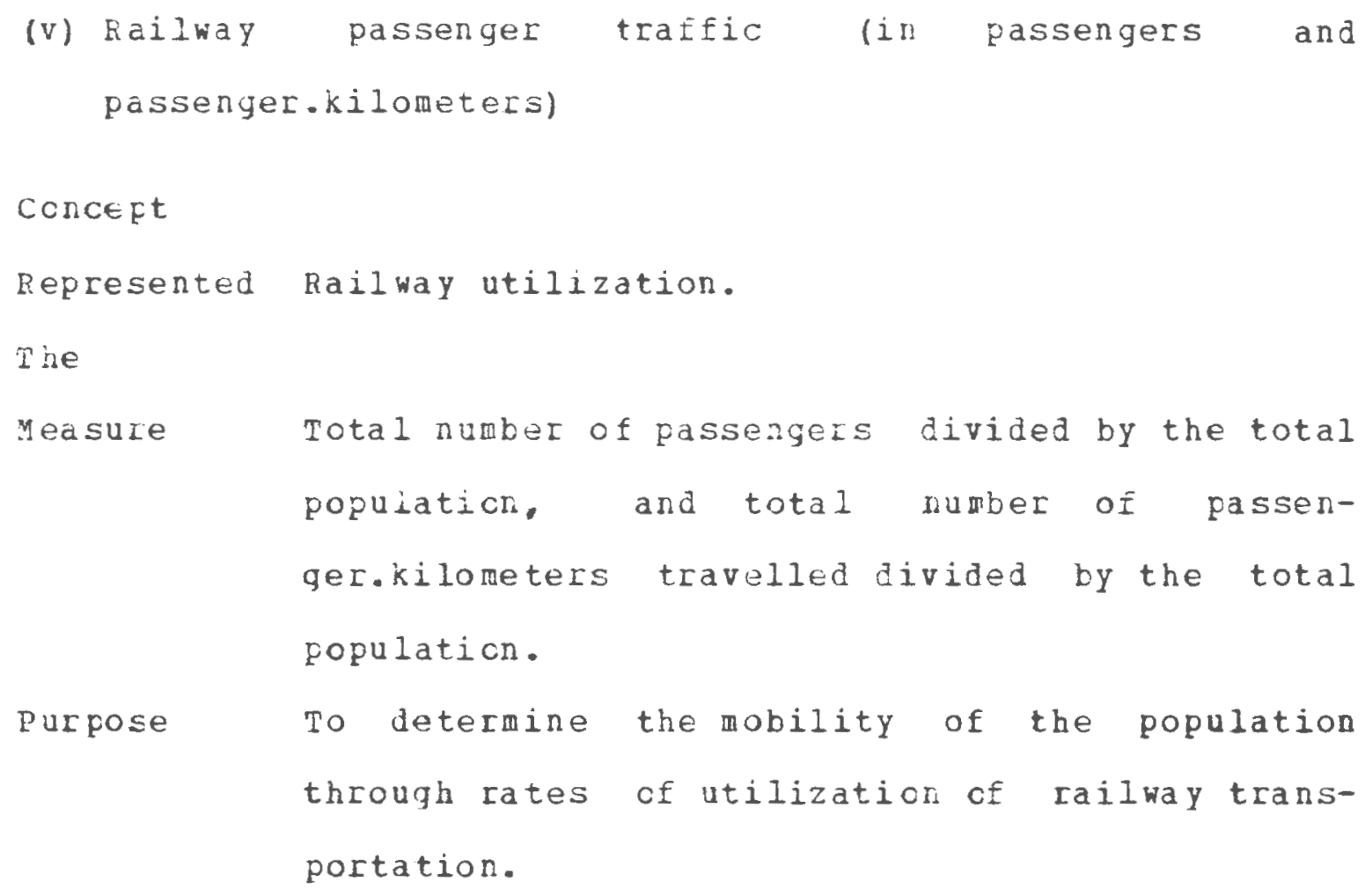


Assumptiors persons having a telephone have better opportunities for commuication, and the number of telephone calls is a measure of the adequacy of verbal comounication at eistance.

Limitations Does not take into account the quality of the communication services and the adequacy of the communication retwork.

(viii) Number of letters per habitant

(ix) " "telegrams" "

Concept

Represented Ability to satisfy the population expectations related to witten comarication.

The

Measure Total number of letters or telegrams yearly issued divided by the total number of habitants.

Purfose To measure the satisfaction of the population expectations related to witten communication. Assumptions Higier values cf these variables indicate better satisfaction of the popliation expectations related to written communication.

Iimitations The quality and efficiency of the postal services and the distributicr cf its utilization through population groups is not taken into account. 
c. culture

(i) Number and use of published books

" " " putlic libraries

Conceft

Represerted Availability arc use of printed material.

The

Measure Number of yearly published bocks, number of books sold and rumber of users of public libraries divided by the total pogulation.

Purfose To measure the cultural opportunities related to the availabiity of printed material.

Limitations The quality and diversity of the publications are not taken into account, as well as the diversity of users.

(iii) Number and diversity of theater performances

(iv) " of theater admissions

Concept

Represented Availability ard attendance of theater performances.

The

Measure Total number of theater performances, number of distinct plays enacted and number of theater admissions per year and per habitant. 
Purpose To measure the population opportunities for attending theati $\in$ performarices.

Assumptions The number and diversity of theatre performances and the number cf theatre admissions are a measure of the fulfilment of the population cultural expectaticns.

Iimitations The quality of glays and performances, the diversity of the fublic and the regional distribution are not taken into account.

(v) Number of visits to museums

(vi) " " " " " " " " monuments
(vii) "

concept

Eepreserted Availability ard use of public art displays.

The

Measure Total numer of yearly visits divided by the total population.

purfose To measure the cpportunities for visiting fublic art displays.

Assumptions Higher values cf these variables indicate better cpportunities for visiting public art displays.

Limitations The quality, civersity and Iccalization are not taken into acccunt, as well as the diversity of visitors. 


\section{Chapter V}

\section{DATA A RALYSIS}

In this chapter, data on the indicators developed through the social indicator model previously described are presented and analyzed. Whenever it was possible to obtain ata for all of the years during the two periods of this study, the following quantities were computed for each of the two periods (1950-59 and 1960-69): the mean, the slope of the regressicn line, and the correlation coefficient. The slofe of the regression line provides the linear trend that better fits the data of the corresponding period. The correlation coefficient gives an indication of the scattering of lata values around the regression line, and, therefore, provides information on the adequacy of the linear trend in describing the changes observed during the period (correlation coefficient equal to +1 or -1 means linearity of data and smaller magnitudes of the coefficient indicate departure from linearity). A comparison of the indicator valves for the two feriods is carried out by comparison of the three quantities just defined.

The gathering of data was difficult and extremely time consuming. as information on social indicators is, in general, deficient. Indirect sources cften hal to be used and, in certain cases, the indicator identified in the model developed had to be replaced by Ielated, but different, variables, or even bypassed due to the unavailability of data. 


\subsection{OUTPUI DESCERIPTIVE INDICATOES}

\section{a) Nut도프므}

It was not possible to obtain data on consumption levels of the several food products identified in the social indicator model developed in the previous chapter. Instead, the total amount, per capita, of each product availabie in the market (domestic production plus imports) is used. Table v.1 contains the corresponding data, as well as information on the protein and calorie contents of animal and vegetal products.

For all frcducts, except cereals, the availability per capita increased from 1950-59 to 1960-69. The increase in mean values was particularly high for meat (95\%), fruit (56\%) and sugar (50\%), and was substantial for $f$ ish, milk, eggs and vegetables (all between 23\% and 33\%). The increase in the mean availability ger capita of potatos (10\%) and the decrease in the availability of cereals $(-10 x)$ were moderate. The linear trends, as measured by the slope of the regression line, show a substantial increase for fish (450\%), cheese (200\%), meat (115\%), cereals (113\%), remained fairly stable for sugar and fruit, and ceclined substantially for vegetables $(-128 \%)$, potato $(-167 \%)$ and ailk $(-200 \%)$. It should, however, be noted that the assumption of linear trerds is not supported by the values of the correlation coefficient for fish in 1950-59, veytables and pctato in 1960-69, and cereals in both periods, but is fairly good for the other products. 
Table V.1 - Indicators related to nutrition in Italy: mean, slope of regression line and correlation coeficient.

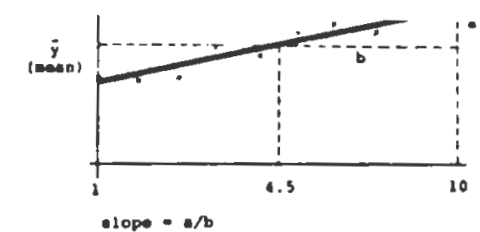

\begin{tabular}{|c|c|c|c|c|c|c|c|c|c|}
\hline \multirow{2}{*}{\multicolumn{2}{|c|}{ INDICATOR }} & \multicolumn{3}{|c|}{$1950-59$} & \multicolumn{3}{|c|}{$1960-69$} & \multicolumn{2}{|c|}{ PERCENT CHANGE } \\
\hline & & mean & slope & $r 1^{\star}$ & mean & slope & $r 2^{\star}$ & mean & slope \\
\hline \multirow{12}{*}{ 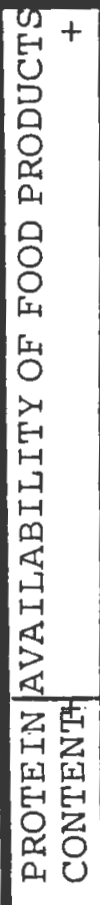 } & Meat $(\mathrm{Kg})$ & 20 & 1.3 & 0.96 & 39 & 2.8 & 0.98 & 95 & 115 \\
\hline & Fish (Kg) & 6.7 & 0.06 & 0.58 & 8.6 & 0.33 & 0.87 & 28 & 450 \\
\hline & Milk (L, r) & 52 & 1.5 & 0.95 & 65 & 0.5 & 0.80 & 25 & -67 \\
\hline & Eggs (Kg) & 7.7 & 0.3 & 0.90 & 9.5 & 0.09 & 0.68 & 23 & -70 \\
\hline & Cheese (Kg) & 6.4 & 0.1 & 0.81 & 8.5 & 0.3 & 0.95 & 33 & 200 \\
\hline & Sugar (Kg) & 16 & 0.8 & 0.99 & 24 & 0.7 & 0.94 & 50 & -13 \\
\hline & Fruit (Kg) & 61 & 2.7 & 0.86 & 95 & 3.3 & 0.95 & 56 & 22 \\
\hline & Vegetables (Kg) & 101 & 5.7 & 0.87 & 133 & -1.6 & -0.40 & 32 & -128 \\
\hline & Cereals ( $\mathrm{Kg})$ & 201 & $-1 \cdot 6$ & -0.45 & 182 & 0.2 & 0.35 & -9 & 113 \\
\hline & Potato (Kg) & 44 & 1.8 & 0.95 & 48 & -1.2 & -0.64 & 9 & -2 \\
\hline & Animal (Grs) & 62 & 1.6 & 0.97 & 79 & 2.1 & 0.98 & 27 & 31 \\
\hline & Vegetal (Grs) & 518 & 0.4 & 0.06 & 519 & 2.4 & 0.70 & 0.2 & 500 \\
\hline \multirow{2}{*}{ 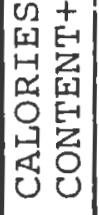 } & Animal & 399 & 9.8 & 0.94 & 498 & 12.9 & 0.98 & 25 & 32 \\
\hline & Vegetal & 2,300 & 6.6 & 0.21 & 2,400 & 19.5 & 0.85 & 4 & 195 \\
\hline
\end{tabular}

* Correlation coeficient (r)

+ Per capita per year

Source: Derived from Appendix A, Table 1 . 
The protein and calorie contents of the animal food products increased from 1950-59 to 1960-69 ky approximately $25 \%$ in the mean and by $30 \%$ in the linear trend. The values for vegetable products remained stable in the mean, but the associated linear trends increased by 500\% for protein and by 200\% for calorie. The linear approximation is fairly good for the animal products, but for vegetable products it is not supported by the values cf the correlation coefficients during the period $19 \leq 0-59$.

It was nct possible to obtain information on the other indicator identified in the model: the demands for food frcm social services.

Summa됴 : The data described above indicate a substantial improvement in the nutrition of the Italian popuiaticn from 1950-59 to 1960-69, not only in absolute values of food products available for consumption, but also in the diet composition, where a shift from cereals and pctato to meat, fruit and Eish occurred.

\section{b) Shelter}

Data on shelter were only available for the years of the general census of the Italian population: 1951, 1961, 1971. The recorded values are given in Table V.2.

The total number of housing units available per habitant in 1951, 19E1 and 1971, was, respectively, $0.24,0.28$ and 0.32 , which correspoud to an increase of 17\% during 1951-61 and 14\% Juring 1961-71. The term "housing unit" is applied here only to structures satisfying the conditions stipulated by italian Law as appropriate for rousing, and, therefore, do not include residences which 
Table V.2 - Indicators related to shelter in Italy: value and percent change in the periods 1951-61 and 1961-71.

\begin{tabular}{|c|c|c|c|c|c|}
\hline \multicolumn{1}{|c|}{ INDICATORS } & 1951 & 1961 & 1971 & $51-61$ & $61-71$ \\
\hline Number of housing units per person & 0.24 & 0.28 & 0.32 & 17 & 14 \\
Number of rooms per housing units & 3.2 & 3.3 & 3.6 & 3 & 9 \\
Percent of occupied housing units & 94 & 92 & 88 & -2 & -4 \\
$\begin{array}{l}\text { Percent of other type of shelter } \\
\text { relative to total housing units }\end{array}$ & 1.7 & 1.2 & 0.32 & -29 & -73 \\
\hline
\end{tabular}

Source: Derived from Append1x A, Table 2. 
do not satisfy minimum housing requirements or were approved for other uses (such as ofrices, shops, etc.).

The percentage of occupied housing units was $94 \%, 92 \%$ and $88 \%$ in 1951, 1961 and 1971, respectively. These figures show a certain increase in the availability of rcn-occupied nousing units, especially during the period 1961-71.

The term "other type of shelter", which appears in the table, refers to sbelter which was not intended for residence or does not satisfy the minimum approved conditions for housing, but was occupied by one or more resident famiiies at the time of the census. The ratio of "other type of shelter" to the number of housing units was 1.7\%, 1.2\% and 0.3\%, for 1951, 1961 and 1971, respectively. This shows a comparative lmprovenent in the housing conditions of the population, which was substantially higher during 1961-71 than $1951-61$.

It vas not possible to obtain sufficient data on services and facilities available in housing urits and on the demand for shelter from social services to make a useful comparison.

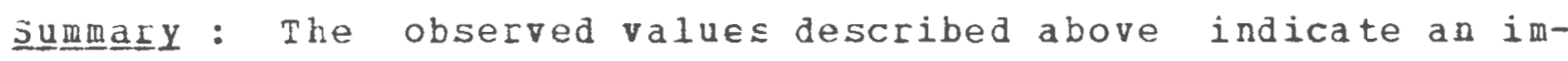
provement in the shelter conditiors of the Italian population from 1951 to 1561 and from 1961 to 1971. This improvement was somewhat bigher ir the secona period. 
c) 브트르는

Table v. 3 provides informaticn on the mear age of death, on mortality rates and on the incidence of certain diseases.

The average of the mean age of death during $1950-59$ was 66 years old, compared to 71 years old fcr 1960-69. The total mortality rate and the infant mortality rate were, respectively, 67 and 62 per thousand habitants, in 1950-59, and 71 and 37 per thousand habitants in 1960-69.

The mean incidence of epidemic and of respiratory diseases decreased substantially from 1950-5 s to 1960-69, but the mean incidence of turors and of circulatory diseases increased from one period to the other.

Sugmmary : The data just described indicate improvement in the health conditions of the populaticn from 1950-59 to 1960-69, except for the incidence of tumors and circulatory diseases wich, usualIy, increase with technological development and with major population migrations from rural to urtan areas.

\section{d) $\underline{\text { Sa }}$ fety}

Information on accidents leading to deatl. by traffic, murders or other causes, is given in Table v.4, together with the number of robkeries reported to the police.

The average number of fatal traffic accidents increased by $40 \%$ from 1950-59 to 1960-69. The average number of nurders decreased by $92 \pi$ frcm the first to the secord period. At the same time, other accidents calsing death decreased, in average, by $34 \%$ from 
Table V.3 - Indicators related to health in Italy: mean, slope of regression line and correlation coeficient.

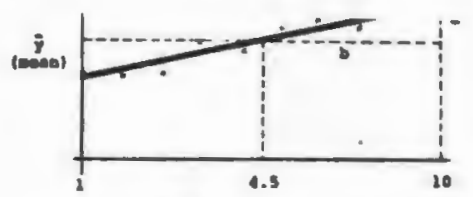

$.2000 \cdot-2 / 0$

\begin{tabular}{|c|c|c|c|c|c|c|c|c|}
\hline \multirow[b]{2}{*}{ INDICATOR } & \multicolumn{3}{|c|}{$1950-59$} & \multicolumn{3}{|c|}{$1960-69$} & \multicolumn{2}{|c|}{ PERCENT CHANGE } \\
\hline & mean & slope & $\mathrm{rl}^{*}$ & mean & slope & $\mathrm{r} 2^{*}$ & mean & slope \\
\hline Mean age of death (1) & 67 & 1.3 & 0.71 & 71 & 0.2 & 0.93 & 6 & -85 \\
\hline $\begin{array}{l}\text { Total mortality rate (1) } \\
\text { per } 1,000 \text { habitants }\end{array}$ & 67 & 1.3 & 0.71 & 71 & 0.2 & 0.93 & 6 & -85 \\
\hline $\begin{array}{l}\text { Infant mortality rate (1) } \\
\text { per } 1,000 \text { live births }\end{array}$ & 62 & -1.2 & -0.39 & 37 & -1.5 & -0.98 & -40 & 25 \\
\hline $\begin{array}{l}\text { Diseases: (1) } \\
\text { per } 1,000 \text { habitants }\end{array}$ & & & & & & & & \\
\hline Epidemic & 0.43 & -0.04 & -0.91 & 0.23 & -0.01 & -0.81 & -47 & -75 \\
\hline Tumors & 1.3 & 0.04 & 0.95 & 1.7 & 0.04 & 0.96 & 31 & 0 \\
\hline Circulatory & 2.6 & 0.10 & 0.84 & 3.4 & 0.17 & 0.74 & 31 & 70 \\
\hline Respiratory & 1.04 & -0.07 & -0.46 & 0.86 & 0.02 & 0.40 & -17 & -129 \\
\hline
\end{tabular}

* Correlation coeficient ( $r$ )

Source: Derived from Appendix A, Table 3 . 
Table V.4 - Indicators related to safety in Italy: mean, slope of regression line and correlation coeficient.

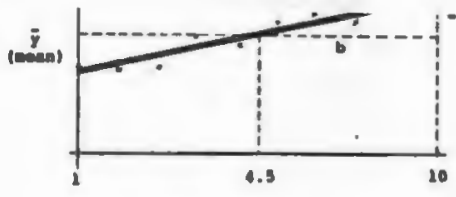

o2ope - as

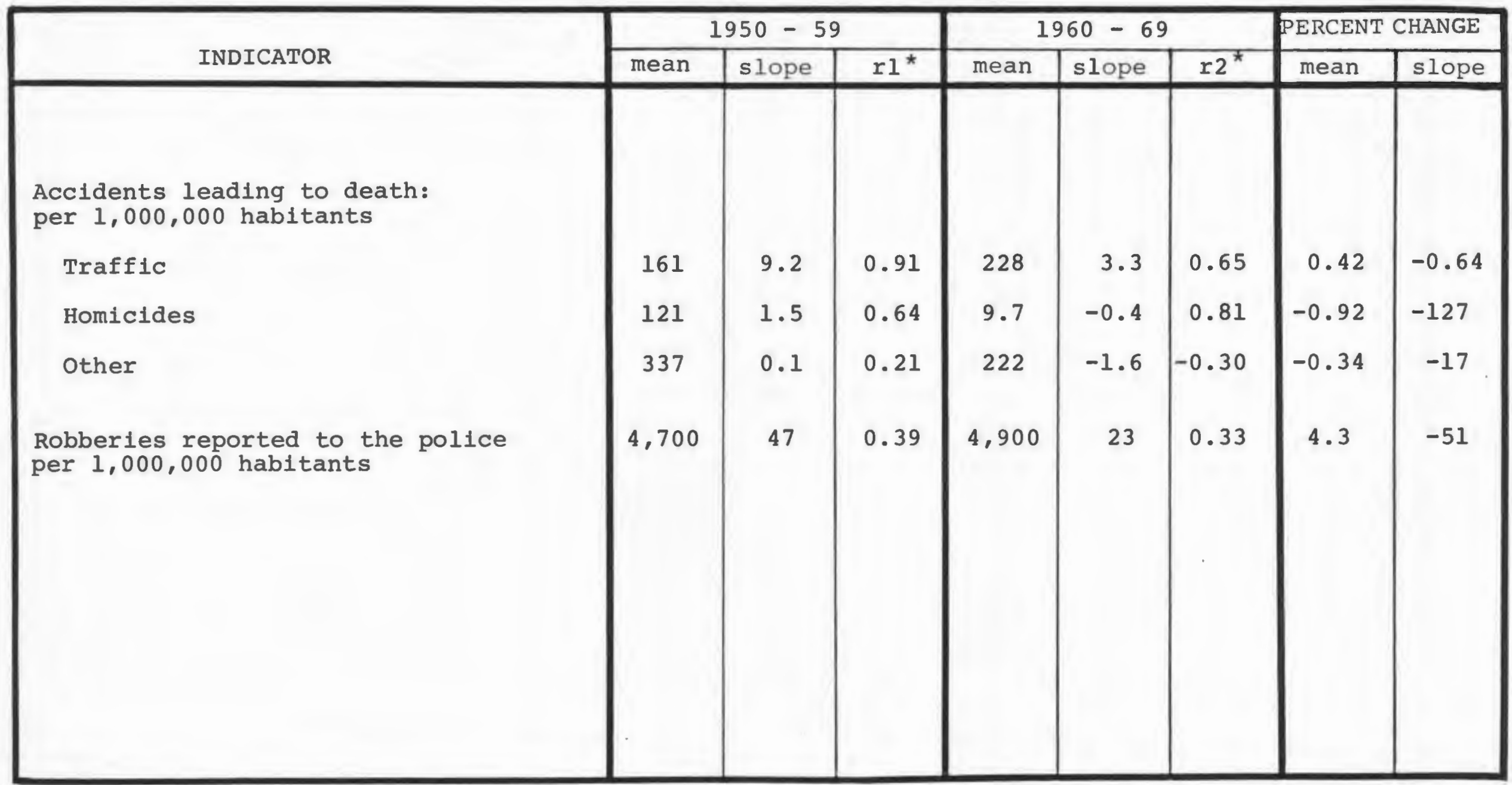

* Correlation coeficient ( $r$ )

Source: Derived from Appendix A, Table 4. 
1950-59 to 1960-69. A comparison of the lirear trends, obtained by regression aralysis, shows a decline in the trends for traffic, murders and other types of accidents leading to death, from 1950-59 to 1960-69, by, respectiveiy, 65\%, 126\% and 1,670\%. However, the assumption of linear trends is nct supported by the value of tine correlatica coefficients, except for traffic accidents in both periods considered, and murders in $1 \subseteq \in 0-69$.

on the other hand, the cases cf robbery reported to the police increased by $7 \%$ from 1950-59 to $1960-69$, and the Iinear trend decreased by $52 \%$, although the observed values are too much scattered around the line of best fit to be considered linear.

SummaI : Relative to the occurrence of crimes, the overail safety increased marked 19 from 1950-59 tc 1960-69, and the increase in the second period was substantially higher. However, traffic safety decreased from the first to the second period, although the line of best fit frcvided For a moderate increasing trend in 1950-59, as compared to a substantiai decreasing trend in 1960-60.

\section{e) $\underline{\underline{E}} \underline{\underline{i}} \underline{\underline{s}} \underline{\underline{r}} \underline{\underline{E}}$}

It was not possible to ortain adequate data or leisure. In particular, the total time available for leisure, the total area available for recreation, and the $t$ se of leisure time could not be found in the available literature. 


\section{f) Educaticn}

Iliteracy and school enrollont data were available only for the years of the general census cf the Italian population: 1951, 1961 and 1971. The corresponding values appear in Table V.5.

The ratio of illiterates to the total population oi age greater or equal to six years old, decreased by $36 \%$ from 1951 to 1961 and by $1.6 \%$ from 1961 to 1971. In 1971 the cbserved illiteracy rate was $5.2 \%$.

The ratio of encolied students to the number of individuals in the corresponding age groups increasea from 1951 to 1961 and from 1961 to 1971. The increases weIE much greater during the second period.

Information on the number of students per teacher was available for all years during the periods considered in this study, and is given in Table V.6. These numbers were 22 and 12 students per teacher by 1970, for the elementary and tae seccndary grades, respectively, and they decreased, ir. average, frcm 1950-59 to 1960-69 by $18 \%$ for the elementary grades (ages $6-10$ years old) and by .05\% for the secordary grades (ages 11-13 years old).

Summary : Illiteracy and the number of students per teacher decreased in both periods of study, with important decreases during the Eirst period and small decreases during the second. However, by the erd of the second period bcth variables were assuming acceptable values. The enrollment ratios in the different school grades increased substantially in both periods, with particularly high values for $1960-69$. 
Table V. 5 - Indicators related to education in Italy: value and percent change in the periods 1951-61 and 1961-71

\begin{tabular}{|c|c|c|c|c|c|}
\hline & \multirow[b]{2}{*}{1951} & \multirow[b]{2}{*}{1961} & \multirow[b]{2}{*}{1971} & \multicolumn{2}{|c|}{ PERCENT CHANGE } \\
\hline & & & & $51-61$ & $61-71$ \\
\hline $\begin{array}{l}\text { Percent of illitera } \\
\quad \text { ( } 6 \text { years old and over) } \\
\text { Percent of school age population } \\
\quad \text { enrolled: }\end{array}$ & 12.9 & 8.3 & 5.2 & -34 & -37 \\
\hline $\begin{array}{l}\text { Elementary and secondary } \\
\text { ( } 6 \text { to } 10 \text { and } 11 \text { to } 13 \text { years old) }\end{array}$ & 88.2 & 90.4 & 102.4 & 2.5 & 13.3 \\
\hline $\begin{array}{l}\text { Advanced } \\
(14 \text { to } 18 \text { years old) }\end{array}$ & 10.6 & 21.8 & 43.7 & 105.7 & 100.5 \\
\hline $\begin{array}{l}\text { University } \\
\text { (19 to } 23 \text { years old) }\end{array}$ & 5.5 & 7.1 & 19.0 & 29.1 & 4.7 \\
\hline
\end{tabular}

Source: Derived from Appendix A, Table 5. 
Table V.6 - Indicators related to education in Italy: mean, slope of regression line and correlation coeficient.

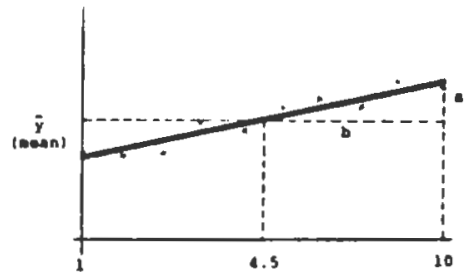

0 lope - as

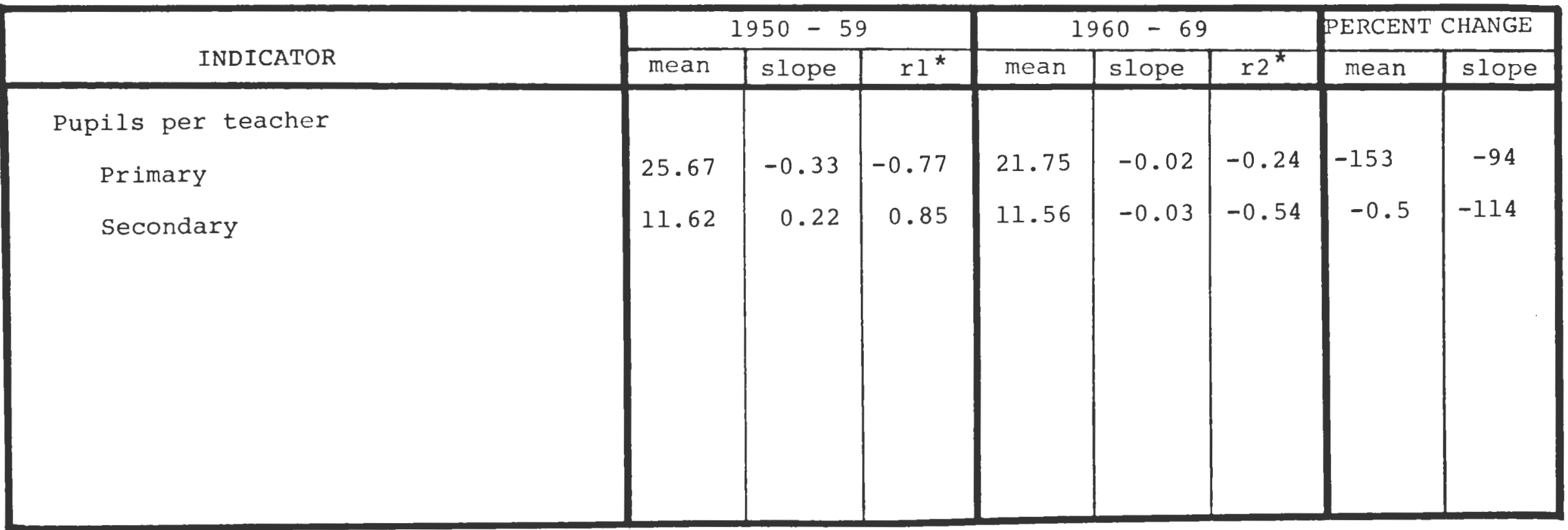

* Correlation coeficient ( $r$ )

Source: Derived from Appendix A, Table 5 . 


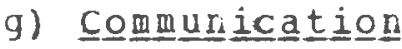

Data on the adequacy of means cf communication were obtained relative to the following variables: number of cari per capita, total length of motorway, total length of railway line open to traffic, railway passenger traffic (passengers and passenger.kilometers), number of telephones and of telephone calls per capita, number of letters and cf telegrams per capita. The values observed for these variables are collected in Table V.7.

The average number of passencer cars per capita increased by 460\% From 1950-59 to 1960-69, anc the average number of commercial vebicles increased by $81 \%$ from on $\in$ period to the other. The correspondirg inear trends also increased from one period to the other, by factors of comparable magritudes. The tctal length of motorway increased, in average, by $\equiv 0 \%$ from the first period of study to the second.

The length of railway and the casserger traffic on the railway both decreased slightly throughoct the two periods, with a more pronounced decrease during the seccnd period.

The number of telephones per capita increased, in average, by $170 \%$ from 1950-59 to 1960-69, and the number of telephone calls per capita increased by $277 \%$. The associated linear trends increased by $54 \%$ and 197\%, respectively.

Both the number of letters and of telegrams per capita increased, in average, by 38t from 1950-59 to 1960-69. The corresponding linear trends decreased significantly from the first period to the second. 
Table V.7 - Indicators related to communication in Italy: mean, slope of regression line and correlation coeficient.

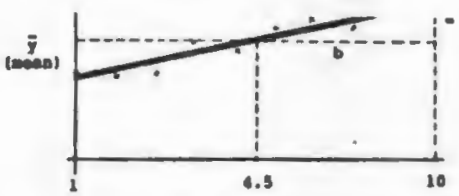

$1000-200$

\begin{tabular}{|c|c|c|c|c|c|c|c|c|}
\hline \multirow[b]{2}{*}{ INDICATOR } & \multicolumn{3}{|c|}{$1950-59$} & \multicolumn{3}{|c|}{$1960-69$} & \multicolumn{2}{|c|}{ PERCENT CHANGE } \\
\hline & mean & slope & $r 1^{*}$ & mean & slope & $r 2^{\star}$ & mean & slope \\
\hline \multicolumn{9}{|l|}{$\begin{array}{l}\text { Number of motor vehicles: } \\
\text { (per } 1,000,000 \text { habitants) }\end{array}$} \\
\hline Passenger cars & 18.10 & 2.85 & 0.99 & 101.61 & 15.16 & 1.00 & 461 & 432 \\
\hline Commercial vehicles & 6.81 & 0.40 & 0.97 & 12.33 & 0.66 & 0.99 & 81 & 65 \\
\hline Total length of motorway ( $\mathrm{Km})$ & 174,979 & $1,485.7$ & 0.94 & 227,809 & $12,775.3$ & 0.93 & 30 & 760 \\
\hline Total length of railway ( $\mathrm{Km})$ & 21,673 & -27.55 & -0.45 & 20,771 & -110.79 & -0.96 & -4.2 & 302 \\
\hline \multicolumn{9}{|l|}{ Railway passenger traffic: } \\
\hline Passenger per capita & 11.24 & -0.02 & -0.25 & 9.47 & -0.36 & -0.94 & -15.8 & 1,700 \\
\hline Passenger.kilometer per capita & 544.70 & 9.93 & 0.94 & 601.89 & -4.93 & -0.62 & 10.5 & $-149 \cdot 7$ \\
\hline $\begin{array}{l}\text { Number of telephones } \\
\text { (per 1,000 habitants) }\end{array}$ & $1,816.8$ & 227.15 & 0.99 & $4,897.2$ & 350.35 & 1.00 & 169.6 & 54.2 \\
\hline $\begin{array}{l}\text { Number of telephone calls } \\
\text { (per 1,000.habitants) }\end{array}$ & 225.5 & 32.5 & 0.98 & 850.8 & 98.0 & 0.99 & 277.3 & 201.5 \\
\hline
\end{tabular}

* Correlation coeficient (r)

Source: Derived from Appendix A, Table 6 . 
Table V.7 - Indicators related to communication in Italy: mean, slope of regression line and correlation coeficient. (cont.)

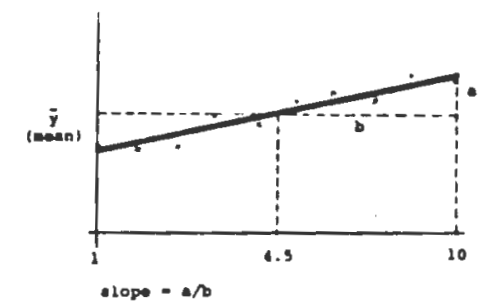

\begin{tabular}{|c|c|c|c|c|c|c|c|c|}
\hline \multirow[b]{2}{*}{ INDICATOR } & \multicolumn{3}{|c|}{$1950-59$} & \multicolumn{3}{|c|}{$1960-69$} & \multicolumn{2}{|c|}{ PERCENT CHANGE } \\
\hline & mean & slope & $r 1^{\star}$ & mean & slope & $r 2^{*}$ & mean & slope \\
\hline $\begin{array}{l}\text { Number of letters } \\
\text { (per 1,000,000 habitants) }\end{array}$ & 79.63 & 4.8 & 0.99 & 109.92 & 1.5 & 0.89 & 38 & -68.8 \\
\hline $\begin{array}{l}\text { Number of telegrams } \\
\text { (per 1,000,000 habitants) }\end{array}$ & 0.66 & 0.01 & 0.85 & 0.66 & -0.03 & -0.82 & 0 & -400 \\
\hline
\end{tabular}

* Correlation coeficient (x)

Source: Derived from Appendix A, Table 6 . 
Summary : The availability of mears for commuication through motor vehicles, telephones, letters, and telegrams increased substantial1y from 1950-59 to 1960-69. Whe linear trends observed in these variables increased significantlyfor the number of vehicles and the number of telephones. The railuay services ard trafic remained almost constant, decreasing only slightly. The linear trends observed in the numer of letters and teiecrams decreased significantly frcm the first period to the second.

\section{h) 므느므르}

It was not possible to obtain adequate data on the fulfillment of the cultural expectations of the population. In particular, the number and use of published books, theater perforinances and public libraries could not be found in the available literature. Some indirect information was obtained cn tine number of visits to museums, art galleries and monuments. These data are given in Table V.8.

The average number of visits tc museums, art gaileries and monuments increased by 57\% from 1950-59 to 1960-69. At the same time, the linear trend associated witt these variables decreased by $110 \%$

Summay : The available data on the fulfillment of cultural expectations of the population are not enough to reach reliable conclusions. However, the number of visits to museums, art galleries and monuments indicate a considerable increase in those cultural activities from $1950-59$ to $1960-6 !$. 
Table V.8 - Indicators related to culture in Italy:

mean, slope of regression line and correlation coeficient.

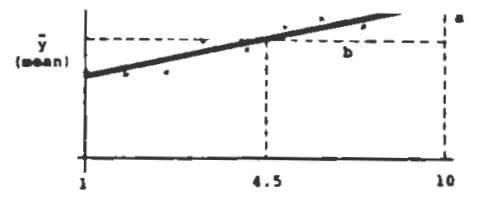

-10pe - .

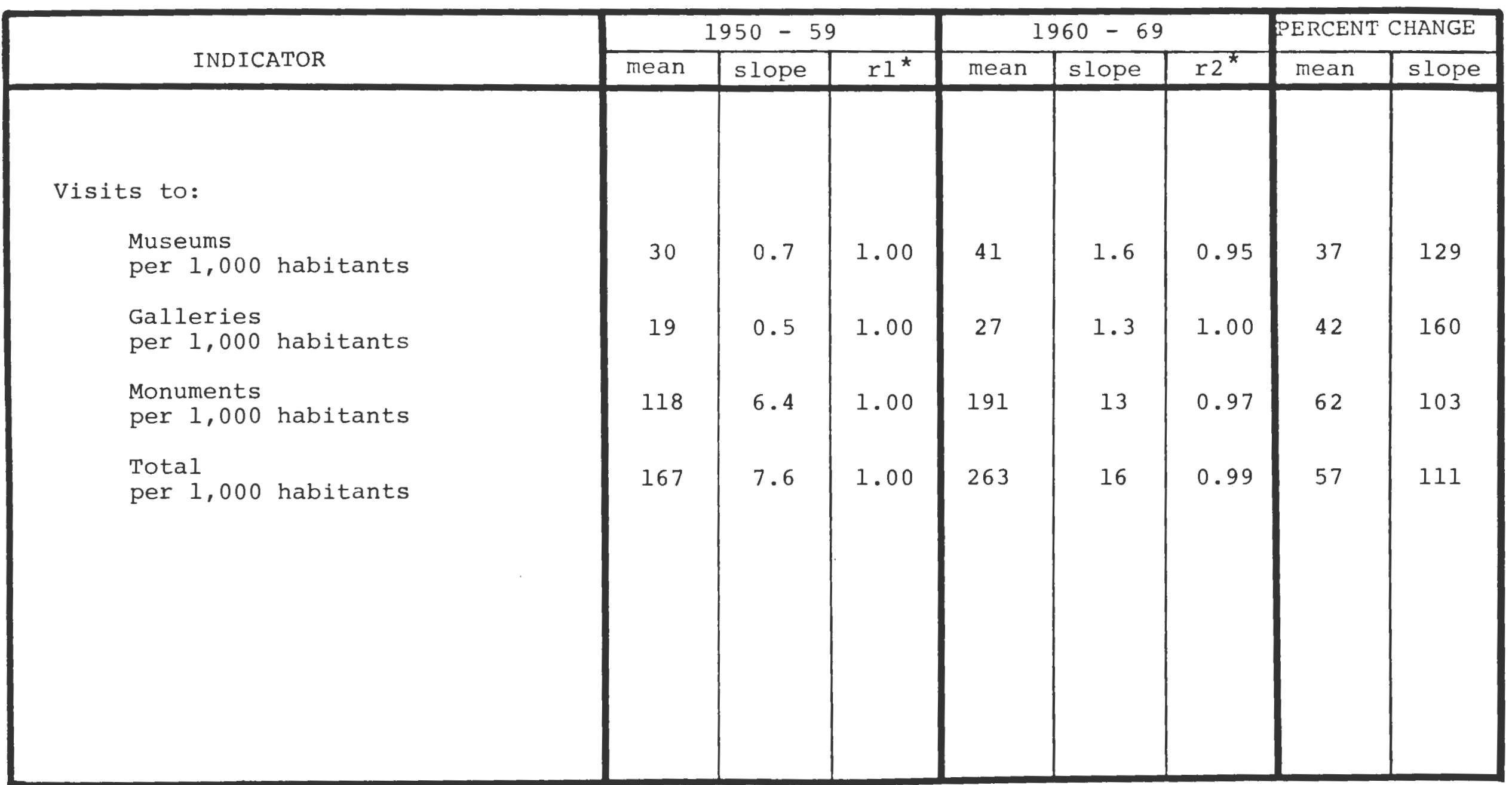

* Correlation coeficient ( $r$ )

Source: Derived from Appendix A, Table 7 . 


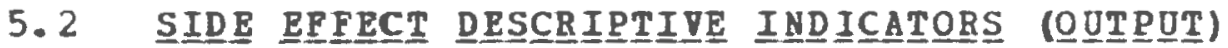

Data on side-efrect descriptive indicators is given in Tables V.9 and $\nabla .10$. It was not pcssible to acquire information on school attendance, school dropout rates, alcohclism and drug abuse. The variables for which data were available are analyzed below. It should be noted that the correlaticn coefficient ci most of the variables indicate high dispersion from the line of best fit, and, tinerefore, tiat the information cr. Iinear trends is not reliable.

\section{a) Emigraticn}

The emiqration rates for the periods $1950-59$ and 1960-69 remained, in average, stable, and the associated linear trends changed considerably from positive in the first period to negative in the seccnd.

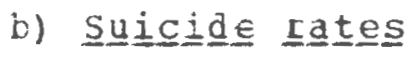

Rates of suicides reported to hospitals decreased, in avarage, from 1950-59 to 1960-69 by 14\% . At the same time, the suicide attempts reported to the police increased from the first period to the second by $9 x$.

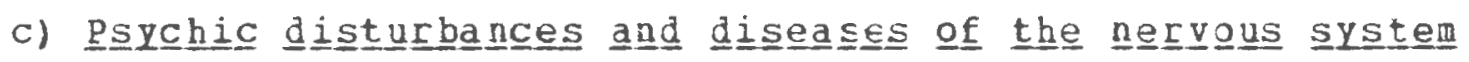

The incidence of psychic disturtances and of diseases of the nervous system decreased, in average, frcm 1950-59 to 1960-59 by $4 x$ 
Table V.9 - Side-Effect Descriptive Indicators

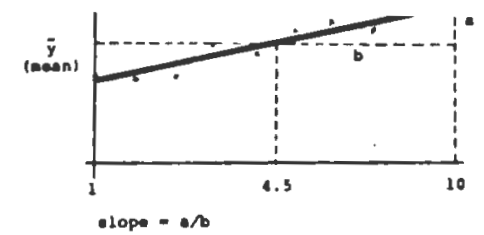

\begin{tabular}{|c|c|c|c|c|c|c|c|c|}
\hline \multirow{2}{*}{ INDICATOR } & \multicolumn{3}{|c|}{$1950-59$} & \multicolumn{3}{|c|}{$1960-69$} & \multicolumn{2}{|c|}{ PERCENT CHANGE } \\
\hline & mean & slope & $\mathrm{rl}^{\star}$ & mean & slope & $12^{*}$ & mean & slope \\
\hline $\begin{array}{l}\text { Emigration } \\
\text { (per 1,000 habitants) }\end{array}$ & 5.69 & 0.11 & 0.35 & 5.64 & -0.47 & -0.94 & -8 & -527 \\
\hline $\begin{array}{l}\text { Suicide rates reported to the hospital } \\
\text { (per million habitants) }\end{array}$ & 64.3 & 0.07 & 0.09 & 55.3 & -0.45 & -0.52 & -0.14 & -743 \\
\hline $\begin{array}{l}\text { Psychic disturbances and diseases of } \\
\text { the nervous system } \\
\text { (per 1,000 habitants) }\end{array}$ & 1.50 & 0.01 & 0.28 & 1.44 & -0.03 & -0.72 & -0.04 & -400 \\
\hline Labor disputes: & & & & & & & & \\
\hline Total number & 65.40 & -2.06 & -0.33 & 47.2 & -8.40 & -0.66 & -28 & 308 \\
\hline Workers involved (in thousands) & 14.90 & -0.68 & -0.18 & 19.00 & -4.41 & -0.54 & 28 & 549 \\
\hline Man Days Lost (in thousands) & 75.40 & -6.35 & -0.27 & 69.30 & -25.22 & -0.54 & -8 & -297 \\
\hline
\end{tabular}

* Correlation coeficient (r)

Source: Derived from Appendix B, Table 1. 
Table V.10 - Side-Effect Descriptive Indicators (cont.)

\begin{tabular}{|c|c|c|c|c|c|c|c|}
\hline \multirow{2}{*}{ INDICATORS } & \multirow{2}{*}{$1953 / 54$} & \multirow{2}{*}{$1956 / 57$} & \multirow{2}{*}{$1960 / 61$} & \multirow{2}{*}{$1965 / 66$} & \multicolumn{3}{|c|}{ PERCENT CHANGE } \\
\hline & & & & & $53-56$ & $56-60$ & $60-65$ \\
\hline $\begin{array}{l}\text { Public vs. Private } \\
\text { Schools: } \\
\text { (primary+secondary) }\end{array}$ & & & & & & & \\
\hline Public (in millions) & 5.3 & 5.8 & 6.2 & 6.9 & 9 & 7 & 11 \\
\hline Private & 0.6 & 0.6 & 0.7 & 0.7 & 0 & 17 & 0 \\
\hline Public/Private & 128 & 118 & 118 & 108 & -9 & 0 & -9 \\
\hline
\end{tabular}

Source: Derived from Appendix B, Table 1. 


\section{d) Labor di $\underline{\text { ingutes }}$}

The average number of labor disputes decreased by $28 \%$ from the period 1950-59 to 1960-69. At the same time, the average of the total number of workers involved in those disfutes increased by 28\%, and the average number of ferson-days lost in related worker strikes decreased by $8 \%$.

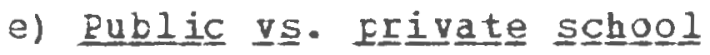

The number of students enrolled in the elementary or the secondary grades of public and private schools is given in Table $\nabla .10$ for tine school years 1953-54, 1956-57, 1960-61 and 1965-66. The percentage of students in private schools, relative to public schools, remained almost constant, but showed a slight tendency to decrease: the observed percentages were 12, 11,11 and 10, for the years 1953-54, 1956-57, 1960-61 and 1965-66, respectively.

Summary : The side-effect indicators for which data were available did not show sigrificant changes from 1950-59 to 1960-69.

\section{3 POLICI IESTROMENT INDICATOORS (INPUT)}

\section{a) Goverrimental bugdget allocation}

The social indicator model developed in chapter IV provides indicators for the share of the national budget assigned to the specified basic luman needs and human expectations. However, from the available data sources, it was crly possible to obtain information 
on the resources allocated to national defense, education, and health and social welfare. The data for the years 1951, 1961 and 1971 are given in Table v.11.

Tire inost important changes ir. the budget allocation were observed in the resources assigned tc education and those assigned to healti and social welfare. In fact, the share of the national budqet assiqned to Education was EX, 17g and 31 in 1951,1961 and 1971. respectively. Relative to kealti and social welfare, the observed percentages were $11 \%, 14 \%$ and 15\%, for the three years above and in the same crder. The share of the national budget allocated to nationai aefense decreased from $18 \%$ to $14 \%$ in the period 1951-61, and increased from 14\% tc 16\% in the period 1961-71.

The composition of imports and exports, in percentages relative to the totais, are given in Tables V.12 and V.13. The imports of food products contributed approximately the same share to the total imports during both periods, 1950-59 and 1960-69. On the other band, a relative increase in impcrts of non-food products occurred from the first to the second pericd, and was accompanied by a corresponding decrease in imports of auxiliary materials. In relation to the compcsition of exports, the percentage of food products decreased significantly, and in a gradual way, from 1950-59 to 1950-69 (20\% in 1950 and $9 \%$ in 1570). While the percentage of imports of ron-food products increased, approximately, by an average of 10 percentage points from the first to the second decade. The percentage of exports of auxiliary materials increased in earlier years of tie first period ( $2 \%$ in 1950 to $11 \%$ in 1954) and decreased 
Table V.11- Policy Instrument Descriptive Indicators Budget Allocation

\begin{tabular}{|c|c|c|c|c|c|}
\hline \multirow[b]{2}{*}{ INDICATORS } & \multirow[b]{2}{*}{1951} & \multirow[b]{2}{*}{1961} & \multirow[b]{2}{*}{1971} & \multicolumn{2}{|c|}{ PERCENT CHANGE } \\
\hline & & & & $51-61$ & $61-71$ \\
\hline National defense & 18 & 14 & 16 & -22 & 14 \\
\hline Health/Social welfare & 63 & 55 & 39 & -13 & -29 \\
\hline Education & 8 & 17 & 31 & 113 & 82 \\
\hline
\end{tabular}

Source: Derived from Appendix C, Table 1. 
Table V.12 - Composition of imports/exports (percentages relative to total)

\begin{tabular}{|l|c|c|c|}
\hline \multicolumn{1}{|c|}{ INDICATORS } & 1950 & 1961 & 1970 \\
\hline Imports: & & & \\
Food products & 22 & 17 & 19 \\
Non food products & 60 & 69 & 67 \\
Auxiliar material & 18 & 14 & 14 \\
& & & \\
Exports: & & & \\
Food products & 26 & 15 & 9 \\
Non food products & 72 & 79 & 86 \\
Auxiliar material & 2 & 6 & 5 \\
\hline
\end{tabular}

Source: Derived from Appendix C, Table 1. 
Table V.13 - Composition of import/export (percentages relative to total value)

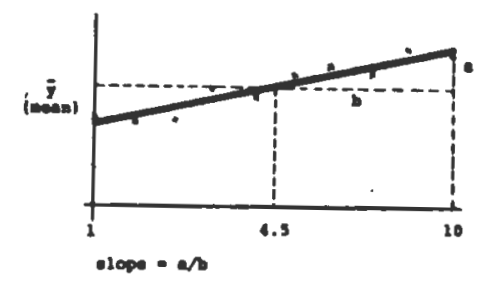

\begin{tabular}{|c|c|c|c|c|c|c|}
\hline \multirow[b]{2}{*}{ INDICATOR } & \multicolumn{3}{|c|}{$1950-59$} & \multicolumn{3}{|c|}{$1960-69$} \\
\hline & mean & slope & $\mathrm{r} 1^{\star}$ & mean & slope & $\mathrm{r} 2^{*}$ \\
\hline \multicolumn{7}{|l|}{ Imports: } \\
\hline Food products & 18.6 & -0.27 & -0.43 & 20.3 & 0.46 & 0.57 \\
\hline Non food products & 61.9 & 0.20 & 0.36 & 65.3 & 0.73 & -0.61 \\
\hline Auxiliar material & 19.5 & 0.08 & 0.25 & 14.5 & 0.24 & 0.56 \\
\hline \multicolumn{7}{|l|}{ Exports: } \\
\hline Food products & 22.6 & -0.44 & -0.53 & 12.1 & -0.81 & -0.98 \\
\hline Non food products & 70.2 & 0 & 0 & 82.4 & 0.84 & 0.95 \\
\hline Auxiliar material & 7.2 & 0.44 & 0.47 & 5.5 & -0.03 & -0.21 \\
\hline . & & & & & & \\
\hline & & & & & & \\
\hline & & & & & & \\
\hline & & & & & & \\
\hline & & & & & & \\
\hline
\end{tabular}

* Correlation coeficlent ( $r)$

Source: Derived from Appendix C, Table 1. 
thereafter, stabilizing around 6\% during the entire period of $1960-69$.

It as nct possible to obtain data on governmental rejulations or incentives for industry and comerce, variables that were stipulated in the model developed in $t$ te previous chapter.

Summary : The important increases in the share of the national budget assiqned to education and to health and scclal welfare indicate the emphasis of governmental policies on these two areas during the periods of study. However, they do cot indicate substantial changes in budget allocation from 1951-61 to 1961-1971. The collposition of imports and exports indicates that the upgrading of the nutrition standards, analyzed in section 1, was achieved through a reduction of exforts whle maintaining the related imported values. This was accompanied by an increase in the imfcrtance of the exports of ner-food products.

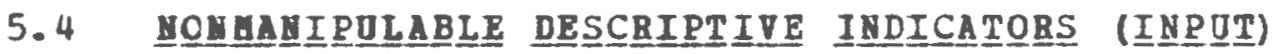

\section{a) Iota 1 fopula}

As Table V.14 shows, tíe pericd 1936-51 was criaracterized by a $12 \%$ increase of total population, considerably higher than the other two periods considered in this stuay $10.5 \%$ in 1951-61 and $6.9 \%$ in 1961-71). The annual averace increase verified in 1936-51 (0.8\%) decreased in 1951-61 (0.6\%) and experienced a sight increase ir. 1961-71 (0.7\%) 
Table V.14 - Total population (in thousands)

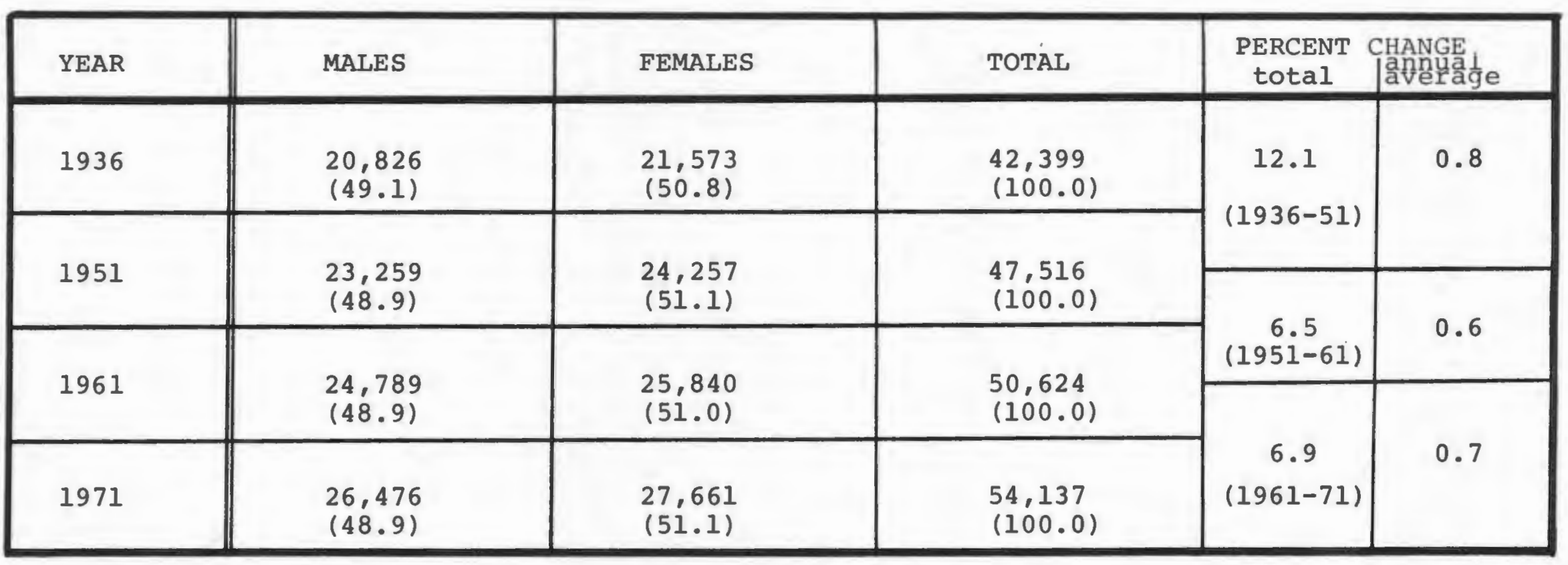

Source: La Population de L'Italie, C.I.C.R.E.D. Series, 1974. 


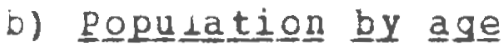

The distribution of the population into a je conorts is given in Table V.15, for the years $1936,1951,1961$ and 1971.

The most characteristic change is the comparative aging of the population. This is clearly illtstrated by the following observations:

(i) in 1936 the laryest cohort appearing in the table was the 15-34 years old ( $32 \%$ of the total population), while, in later years, it became the $35-64$ years cld cohort ( $34 \%$ of tine total population in $1951,35 \%$ in 1961 and $37 \%$ in 1971):

(ii) the relative share of the age group of persons over 65 years ola increased steadly throcghout time: the percentages of this age group relative to the tctal population for the four years considered were, respectively, $7.5 \%, 8.2 \%, 9.5 \%$ and $11.5 \%$;

(iii) the share of the youngest cohort $(0-4$ years old) in the total population decceased by one fercentage point from 1936 to 1951 and from 1951 to 1961, and remained stable from 1961 to 1971, assuming the value of $8 \%$ in this latter year.

\section{c) Eopulaticn by sex}

The ratic of female populaticn to male population (see Table V. 15) was stable throughout the entire period considered, showing just a slight tendency to increase in the later years. 
Table V.15 - Population by age and sex

\begin{tabular}{|c|c|c|c|c|c|c|c|c|c|c|c|c|c|c|c|}
\hline & $M$ & $\begin{array}{r}936 \\
\quad F\end{array}$ & $\mathrm{~T}$ & $\mathbf{M}$ & $\begin{array}{cccc}1 & 9 & 5 & 1 \\
& & F\end{array}$ & $\mathrm{~T}$ & $36-51$ & M & $\begin{array}{llll}1 & 9 & 6 & 1 \\
& & F & \end{array}$ & $\mathrm{~T}$ & $\mid \begin{array}{l}8 \\
51-61\end{array}$ & $\mathbf{M}$ & $\begin{array}{llll}1 & 9 & 7 & 1 \\
& F & \end{array}$ & $\mathrm{~T}$ & 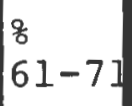 \\
\hline $0-4$ & 2,218 & 2,140 & $\begin{array}{c}4,358 \\
(10.2)\end{array}$ & 2,219 & 2,113 & $\begin{array}{l}4,332 \\
(9.1)\end{array}$ & -0.6 & 2,152 & 2,044 & $\begin{array}{l}4,197 \\
(8.3)\end{array}$ & -3.1 & 2,266 & 2,150 & $\begin{array}{l}4,416 \\
(8.3)\end{array}$ & \pm 5.2 \\
\hline $5-14$ & 4,443 & 4,328 & $\begin{array}{l}8,771 \\
(20.4)\end{array}$ & 4,123 & 3,967 & $\begin{array}{l}8,090 \\
(17.1)\end{array}$ & -7.8 & 4,190 & 4,019 & $\begin{array}{c}8,208 \\
(16.3)\end{array}$ & +1.5 & 4,504 & 4,293 & $\begin{array}{l}8,797 \\
(16.6)\end{array}$ & +7.2 \\
\hline $15-34$ & 6,910 & 6,909 & $\mid \begin{array}{l}13,819 \\
(32.2)\end{array}$ & 7,441 & 7,543 & $\begin{array}{r}14,984 \\
(31.5)\end{array}$ & +8.4 & 7,796 & 7,712 & $\begin{array}{c}15,508 \\
(30.6)\end{array}$ & +3.5 & 7,705 & 7,579 & $\begin{array}{l}15,284 \\
(28.8)\end{array}$ & -1.4 \\
\hline $35-64$ & 5,987 & 6,786 & $\mid \begin{array}{l}12,773 \\
(29.8)\end{array}$ & 7,719 & 8,496 & $\begin{array}{r}16,215 \\
(34.1)\end{array}$ & +30.0 & 8,605 & 9,278 & $\begin{array}{c}17,883 \\
(35.3)\end{array}$ & +10.3 & 9,411 & 10,057 & $\begin{array}{c}19,468 \\
(36.7)\end{array}$ & +8.9 \\
\hline $65+$ & 1,511 & 1,688 & $\begin{array}{c}3,199 \\
(7.5)\end{array}$ & 1,758 & 2,137 & $\begin{array}{l}3,895 \\
(8.2)\end{array}$ & +21.8 & 2,040 & 2,787 & $\begin{array}{l}4,827 \\
(9.5)\end{array}$ & +23.9 & 2,551 & 3,552 & $\begin{array}{l}6,103 \\
(11.5)\end{array}$ & +26.4 \\
\hline TOTAI & 21,069 & 21,851 & 42,920 & 23,259 & 24,257 & 47,516 & +10.7 & 24,784 & $25,840 \mid$ & 50,624 & +6.5 & 26,437 & $|27,631|$ & 53,068 & +4.8 \\
\hline
\end{tabular}

Source: European Historical Statistics 1750-1975, B.R.Mitchell, Facts on File 


\section{d) Fertility}

Fertility rates, as presented in Table V. 16, decreased from 94 births per 1.000 females in 1930-32 to a value of 69 in 1950-52, increasirg slightly to a value cf 74 in 1960-62 and decreasing again to 68 1970-72.

Regional differences are worth mentioning, as they show a large discrepancy between the fertility rates in the Northern areas when contrasted to the southern areas cf the courtry. In fact, fertility rates in the south were close to double of those in the Northwest, although this gap showed a tendency to decrease during $1970-72$.

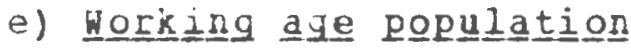

The potential working force, defined by the relative size of the age group 15 to 64 years old, jumfed, batween 1951 and 1961, from 62\% of the total population to akout approximately 66\%, and remained stable from 1961 to 1971.

The active population by major industrial groups, for 1936, 1951 and 1961 (see Table V.17). shows a considerable decrease in the population group comitted to agriculture, forestry, and fishing. Actually, during the period 1936 to 1951 , the share of this group to the total working age populaticn decreasel tc about one-hali of its initial value (48\% in 1936 and $29 \%$ in 1961). The population group Horking in commerce and Finance also experienced, between 1936 and 1951, a decrease of its share to the total population, from $9 \%$ to $1 \%$. The losses observed in these two groups 
Table V.16 -Fertility rate by region (births per 1,000 females)

\begin{tabular}{|c|c|c|c|c|c|c|}
\hline \multirow{2}{*}{ YEARS } & \multicolumn{5}{|c|}{ REGIONS } & \multirow{2}{*}{ ITALY } \\
\hline & NW & $\mathrm{NE}$ & CENTER & $\bar{S}$ & ISLANDS & \\
\hline $1930-32$ & 68.7 & 89.2 & 87.3 & 127.5 & 112.3 & 94.4 \\
\hline $1950-52$ & 48.3 & 57.8 & 58.7 & 95.2 & 92.5 & 69.2 \\
\hline $1960-62$ & 59.2 & 65.4 & 63.7 & 96.8 & 91.2 & 74.0 \\
\hline $1970-72$ & 60.0 & 62.1 & 61.6 & 84.1 & 80.5 & 68.4 \\
\hline
\end{tabular}

Source: La Population de L'Italie, C.I.C.R.E.D. Series 1974. 
Table V.17 - Economically active population by major industrial group (in thousands)

\begin{tabular}{|c|c|c|c|c|c|c|c|c|}
\hline YEAR & $\begin{array}{l}\text { AGRICULT. } \\
\text { FORESTRY } \\
\text { FISSHING }\end{array}$ & $\begin{array}{l}\text { EXTRACTIE } \\
\text { INDUSTRY }\end{array}$ & $\begin{array}{l}\text { MANUFACT. } \\
\text { INDUSTRY }\end{array}$ & CONSTRUCT & $\begin{array}{l}\text { COMMERCE } \\
\text { FINANCE }\end{array}$ & $\begin{array}{l}\text { TRANSP. } \\
\text { COMMUNIC. }\end{array}$ & SERVICES & OTHERS \\
\hline 1936 & 8,843 & 128 & 4,049 & 979 & 1,605 & 35,702 & 1,820 & 219 \\
\hline 1951 & 8,261 & 4,81 & & 1,473 & 176 & 54,785 & 4,065 & - \\
\hline 1961 & 5,657 & & 7,886 & & & $5,9^{\prime}$ & & \\
\hline 1971 & 3,242 & 6,32 & 23 & 2,026 & 2,810 & 992 & 3,437 & 975 \\
\hline
\end{tabular}

Source: European Historical Statistics 1750-1975, B.R. Mitchell, Facts on File. 
(AgriculturetForestry+Fishing ard comercetFinance), during 1936-1951, reverted in favor of the construction and the services industries, which gained 2 and 10 percentage points, respectively. The last decade is characterized ty a steady decline in the population involved ia Agriculture, anc by a growth of more than 100\% in the commerce and Finance sectors. Most of the remaining sectors experienced increases, although these are difficult to assess for some of the sectors, due to changes in the classification system.

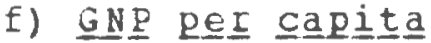

The real GNP per capita (see Tarle V.18) increased at a faster annual average rate in the period 1958-61 (8\%), than in 1948-51 (7\%) or 1951-58 (5\%). This pattern was also observed in the Industrial production Index for the sade periods.

The total GDP, at market prices, experienced a rate of increase of over 1Co\% in the first decade of the period under study, and grew approximately 77\% during 1951-61. Furthermore, the rate of increase cf the GDP per capita dcubled in the second decade under study.

Sumpary : Italy experienced a considerable aging of its population during the period of study. At the same time, the working age group of tie population (15-64 years old) was increasing its share of the total population from $62 \%$ in 1951 to $65 \%$ in both 1961 and 1971. The considerable differences in the demcgraphic characteristics between the Nortin and the souti of the country persisted throughout the period of study, but showed a tendency to decrease, 
Table V.18 - GNP, total and per capita of population resident

\begin{tabular}{|clccc|}
\hline \multirow{2}{*}{ YEAR } & $\begin{array}{l}\text { POPULATION } \\
\text { RESIDENT }\end{array}$ & $\begin{array}{c}\text { ROTAL } \\
\text { (bilions lire })\end{array}$ & $\begin{array}{c}\text { Per resident } \\
(1,000 \text { lire })\end{array}$ & $\begin{array}{c}\text { INDUSTRIAL } \\
\text { PRODUCTION }\end{array}$ \\
\hline 1948 & 46,542 & 8,497 & 182.6 & 63.5 \\
1951 & 47,516 & 10,511 & 221.2 & 88.5 \\
1958 & 49,530 & 14,882 & 300.5 & 142.4 \\
1961 & 50,464 & 18,663 & 369.8 & 199.7 \\
\hline
\end{tabular}

Source: Growth and structure in the economy of modern Italy, George H. Hildebrand, Harvard University Press, 1965. 
in particular, through the closing of the gap in fertility rates between the two regions. The GMP per capita increased throughont the period of time considered, but this increase was more important during 1948-51 and 1958-61 than during 1951-61.

\subsection{ABALITIC IMDICATORS (IMTEBHAI)}

Table v.19 contains data on employment, yages, saving deposits, number of health care structures, and nunber of schools.

\section{a) Enplornent}

The unemployment rate decreased from an average of $9 \%$ in 1950-59 to an average of $3 \%$ in 1960-69. As the values of the correlation coefficients illustrate, the unemfloy aent rate decreased almost 1inearly by 0.3 percentage points per year, during the first period, but shoved randow fluctuations during the second period. These are associated with the achievement cf almost full employment during that pericd.

Relative to employment by sectors, a significant average decrease of employment was observed in the agricultural sector (from 36 In 1950-59 to $26 x$ in 1960-69). vhich was very close to linear. and had alucst equal trends in both periods of study. This decrease in the emfloyment in the agricultural sector was accompanied by increases of employment in the industrial sector. 


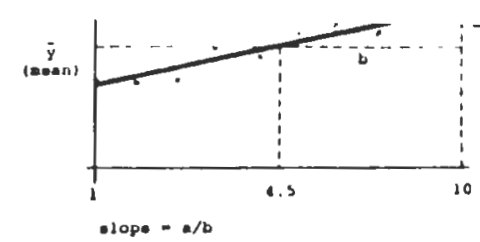

\begin{tabular}{|c|c|c|c|c|c|c|c|c|}
\hline \multirow[b]{2}{*}{ INDICATOR } & \multicolumn{3}{|c|}{$1950-59$} & \multicolumn{3}{|c|}{$1960-69$} & \multicolumn{2}{|c|}{ PERCENT CHANGE } \\
\hline & mean & slope & $\mathrm{rl}{ }^{*}$ & mean & slope & $r 2^{\star}$ & mean & slope \\
\hline $\begin{array}{l}\text { Unemployment } \\
\text { (Percent of total labor) }\end{array}$ & 8.50 & -0.36 & 0.79 & 3.40 & 0 & 0 & -60 & -100 \\
\hline \multicolumn{9}{|c|}{$\begin{array}{l}\text { Employment by sector: } \\
\text { (Percent of total labor force employed ) }\end{array}$} \\
\hline Agriculture & 36.39 & -0.95 & -1.00 & 26.05 & -0.99 & -0.98 & -28 & 4 \\
\hline Industry & 34.04 & 0.44 & 0.95 & 40.47 & 0.48 & 0.93 & 19 & 9 \\
\hline Other & 29.57 & 0.50 & 0.99 & 33.48 & 0.52 & 0.98 & 13 & 4 \\
\hline \multicolumn{9}{|l|}{$\begin{array}{l}\text { Wages indices: } \\
(1955=100)\end{array}$} \\
\hline Agriculture & 97.00 & 4.47 & 0.99 & 182.90 & 16.68 & 1.00 & 89 & 273 \\
\hline Industry & 100.22 & 4.37 & 1.00 & 170.80 & 11.69 & 0.99 & 70 & 168 \\
\hline $\begin{array}{l}\text { Saving deposits } \\
\text { (corrected to } 1971 \text { prices) }\end{array}$ & 6.6 & 0.68 & 0.99 & 17.3 & 1.3 & 0.99 & 162 & 91 \\
\hline Number of health care structures & 46.17 & 3.17 & 0.70 & 48.09 & -0.7 & -0.89 & 4 & -122 \\
\hline \multicolumn{9}{|l|}{ Number of schools } \\
\hline Primary & 42,948 & 834.56 & 0.99 & 46,445 & $|-776.94|$ & 0.96 & 8 & -193 \\
\hline Secondary & 6,949 & 193.04 & 0.95 & 9,485 & 75.31 & 0.63 & 36 & -61 \\
\hline
\end{tabular}

* correlation coeficient (r)

Source: Derived from Appendix D, Table 1, 2. 
b) 브므e indic도오

The wage indices for agriculture normalized to 100 in 1955, increased 1 inearly by an average of 5 points per year in 1950-59 and by 17 points per year in 1960-69. while for industry they increased linearly by 4 points per year in the first period and by 12 points per year in tine second period.

At the same time, as Table V. 20 shows, the purchasing power of the Italian currency, normalized to 100 in 1955, decreased linearly by an average of 4 points per year in 1950-59 and by an average of 3 points fer year in 1960-69. Consequently, the purchasing power of the working population increased dramatically, in average, from the first period to the second.

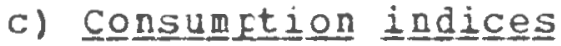

The consumption indices were available for two separate periods of time, 1950-65 and 1967-70, using two different normalizations: the values for the first period we normalized tc 100 for 1955 and those for the second were normalized to 100 for 1970. Table V.21 contains information relative to the regression analysis for the periods 1950-59, 1960-65 and 1967-70. The correlation coefficients indicate the trends are very close to linear, and, therefore, the value for 1966 can be estimated, from above and below, by linear extrapolaticn. These estimates can then be used to adjust the values for 1967-70 to a common normalization of 100 for 1955. The informaticn relative to the regression analysis based on the adjusted indices, for the periods 1950-59 and 1960-69, is given in Table V.22. 
Table V.20 - Purchasing power of the Italian population

\begin{tabular}{|c|c|c|}
\hline YEAR & $\begin{array}{c}\text { PURCHASING POWER } \\
1955=100\end{array}$ & $\begin{array}{l}\text { MEAN, SLOPE OF REGRESSION } \\
\text { AND CORRELATION COEFICIENT }\end{array}$ \\
\hline $\begin{array}{l}1950 \\
1951 \\
1952 \\
1953 \\
1954 \\
1955 \\
1956 \\
1957 \\
1958 \\
1959\end{array}$ & $\begin{array}{c}123 \\
112 \\
108 \\
106 \\
103 \\
100 \\
95 \\
93 \\
89 \\
90\end{array}$ & $\begin{aligned} \text { Mean } & =102 \\
\text { Slope } & =-4 \\
r^{*} & =-0.97\end{aligned}$ \\
\hline $\begin{array}{l}1960 \\
1961 \\
1962 \\
1963 \\
1964 \\
1965 \\
1966 \\
1967 \\
1968 \\
1969\end{array}$ & $\begin{array}{l}87 \\
85 \\
81 \\
75 \\
71 \\
68 \\
67 \\
65 \\
64 \\
63\end{array}$ & $\begin{aligned} \text { Mean } & =73 \\
\text { Slope } & =-3 \\
r^{*} & =-0.97\end{aligned}$ \\
\hline
\end{tabular}

* Correlation coeficient ( $r$ )

Source: Annuario Statistico Italiano

Instituto Centrale di Statistica,

iinistero dell'Economia ivazionale, Italy, 1948-1972 
Table V. 21 - Analytic indicators, consumption indices

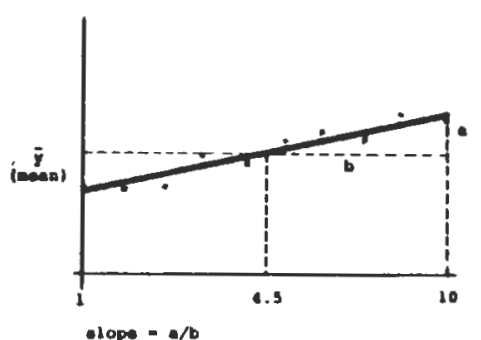

\begin{tabular}{|c|c|c|c|c|c|c|c|c|c|}
\hline \multirow[b]{2}{*}{ INDICATOR } & \multicolumn{3}{|c|}{$195.0-59$} & \multicolumn{3}{|c|}{$1960-65$} & \multicolumn{3}{|c|}{$1967-70$} \\
\hline & mean & slope & $r l^{*}$ & mean & slope & $122^{\star}$ & mean & slope & $123^{*}$ \\
\hline Food & 100.50 & 2.70 & 0.96 & 122.66 & 6.23 & 0.98 & 97.12 & 2.90 & 0.97 \\
\hline Clothing & 101.10 & 0.33 & 0.21 & 114.33 & 4.74 & 0.98 & 95.88 & 4.68 & 0.96 \\
\hline Energy & 98.50 & 1.48 & 0.79 & 105.33 & 2.46 & 0.96 & 97.24 & 2.53 & 0.87 \\
\hline Housing & 119.50 & 16.05 & 0.89 & 347.00 & 30.51 & 0.98 & 94.76 & 4.37 & 1.00 \\
\hline Other services & 98.50 & 2.77 & 0.96 & 29.00 & 6.69 & 0.99 & 97.10 & 3.80 & 0.96 \\
\hline General & 99.10 & 3.29 & 0.99 & 130.33 & 6.86 & 0.99 & 96.84 & 3.46 & 0.97 \\
\hline & & $1938=1$ & & & $1938=1$ & & & $70=100$ & \\
\hline
\end{tabular}


Table V.22 - Analytic Indicators, consumption indices. $(1938=1)$

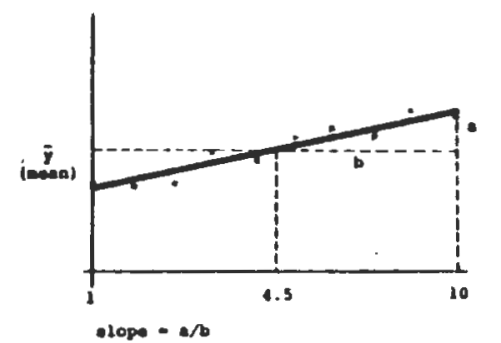

\begin{tabular}{|c|c|c|c|c|c|c|c|c|}
\hline \multirow[b]{2}{*}{ INDICATOR } & \multicolumn{3}{|c|}{$1950-59$} & \multicolumn{3}{|c|}{$1960-69$} & \multicolumn{2}{|c|}{ PERCENT CHANGE } \\
\hline & mean & slope & $r 1^{\star}$ & mean & slope & $r 2^{\star}$ & mean & slope \\
\hline Food & 100.50 & 2.70 & 0.96 & 133.50 & 5.42 & 0.98 & 33 & 101 \\
\hline Clothing & 101.10 & 0.33 & 0.21 & 124.10 & 4.83 & 0.99 & 23 & 1364 \\
\hline Energy & 98.50 & 1.48 & 0.79 & 109.90 & 2.21 & 0.97 & 12 & 49 \\
\hline Housing & 119.50 & 16.05 & 0.89 & 398.10 & 26.44 & 0.99 & 233 & 65 \\
\hline Other services & 98.50 & 2.77 & 0.96 & 141.70 & 6.31 & 0.99 & 44 & 128 \\
\hline General & 99.10 & 3.29 & 0.99 & 142.50 & 6.13 & 0.99 & 44 & 86 \\
\hline
\end{tabular}

* Correlation coeficient ( $r$ )

Source: Derived from Appendix D, Table 3. 
The most dramatic zncreases in consumption indices occurred for housing costs. These increased at average linear rates of 16 and 26 for 1950-59 and 1960-69, respectively. The food consumption indices increased at averaqe yearly rates of 3 and 5 for each one of the two decades, and the clotling consumption indices increased at yearly rates of 0.3 and 5 , respectively. Consequently, the food consumption indices increased at a rate slightly lower than the decrease in the purchasing pcwer of the Italian curcency (reported ir Table $v .20$ ) during $195 \mathrm{C}-59$, and they increased at a rate sliqhtly hiqher than the currency purchasing power during 1960-69. However, the consumption indices in clothing increased at a much lower rate than the decrease in the curcency purchasing power during the first period, and they increased at a slightly higher rate than the currency purchasing pow $\in$ I during the second period. As for housing, the consumption increased at a much higher rate than the decrease in the Italian currency purchasing power.

\section{d) savings deposits}

Table V. 19 contains informaticn on the total amour.t of savings deposits, after correction to constant Italian lire of 1971 . The observed values are fairly close tc linear in both periods of study, as the correlation coefficients illustrate. The average values of savings deposits is considerably higher in 1960-69 (17.3 billion of 1971 Iice) than in 1950-59 (6.t bilizon of 1971 lire), and the same is true of the linear trends $(1.3$ billion per year in 1960-69 and 0.68 billion fer year in 1950-59). 


\section{e) Nubber of schocls}

Information on the number of elementary and secondary schools is given in Table 7.19 . Igain, data were only available for part of the periods of interest. During the whole period of study, the number of conpulsory school years was constant: 8 years covering the age group of 6 to 14 years old.

The number of elementary schools increased, in average, from a value of 43 thousand in 1950-59 tc 46 thousand in 1969-70, increasing with a substantially high linear rate (835 per year) during the first decade and decreasing during the second decade with a linear rate of the same magnitude (777 per year). The number of secondary schools increased, in average, from 7 to 10 thousand, from the first to the second decade, and the observed linear rates of increase vere high (193 per year) in the first period and moderate (75 per year) in the second.

\section{f) Healtb care infrastructures}

Table V.19 includes informaticn on the number of health care structures. From 1950-59 to 1960-69 the average values increased 4\%. but alnost all of this increase occurred during the first decade. Actually, during the second decade the regression line has a negative slope.

Sumary : The employment situation changed frow low unemployment rates in 1950-59 to a state cf virtually full employment in 1960-69, a change that was accompanied by an important shift of the working force from the agricultural to the industrial sectors. The 
wage indices, corrected to constant lire, indicate a major increase in the overall purchasing pover of the working population, from the first to the second decade. At the same time, the consumption indices indicate a disproportionately high increase in the consumption in housing wich, however, does not seem to have affected the financial resources allocated to focd, and, in fact, still alloved a marked increase in the consumption in clothing. The data on savings deposits shov an accentuated increase from 1950-59 to 1960-69. both in average values and in linear trends, indicating improved satisfaction of the monetary needs of the population, since higher levels of saving could be afforded in the second decade. The number of elementary schools remained almost constant from the first to the second decade, while the number of secondary schools increased considerably. The number of health care structures increased, in average, from 1950-59 to 1960-69, but this increase was alnost all due to changes verified during the first decade. 
Chapter VI

CONCL tSIORS

\subsection{SUABABI OF RESOLTS}

The time series analysis of the indicators described in the preceding chapter, especially tbe observations of the output descriptive indicators, indicates a considerable improvement in the quality of life of the Italian pcpulation from 1950-59 to 1960-69. A11 of the descriptive indicators, for which data vere available. indicate a significant inprovement in the quality of life from the first to the second decade, exceft for the component of safety associated with traffic accidents. The side-effect descriptive indicators did not experience significant differences between the tro periods. The policy instrument indicators suggest that a greater emphasis was placed upon policies related to the improvement of the quality of life than on defense interests. The nonmanipulable descriptive indicators show that the favorable changes verified from one decade to the other were accompanied by a considerable aging of the Italian population, and that the GNP increased much more during the first decade than during the second. The analysis of tbe anaIItic indicators shous a very significant improvement, from the first to the second decade, in employment, purchasing porer and saving deposits, changes that, indirectly, indicate a substantial improvement in the quality of life in Italy. 
Because the participation of Italy in the $\Xi E C$ began in 1958, it may be argued that the improvements verified in the quality of life of the Italian population were associated with the entrance of the country intc that international organization. This is, in fact, the conciusion of the time series aralysis ferformed in the preceding chapter, but it is limited by the methodology characteristic of time series studies, as is emphasized in the jollowing section.

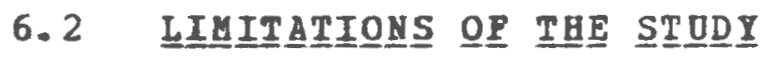

The main objective of the present work was the development of a framework for ar analytical model to guide the choice of social indicators characterizing the quality of life at the level of a nation. The evaluation of the impact of Italy's membership in the EEC on the quality of life was used as a case study of the application of the general methodology develoged. However, it is of interest to point out some of the most important limitations involved in this application.

The present study was exclusively based on a time series analysis of several indicators relevant to the problem under consideration. However, general underlyirg conditions have changed during the period of study, as a consequence of changes in the international eccnomy. of technological advances, and of changes in life style ana sccial values. Consequently, in orjer to obtain reliable conclusions on the impact of the atobership of Italy in the EEC on the quality of life of her popliation, it woula be necessary to de- 
velop a control systen consisting of one or more countries which had similar characteristics to Italy, prior to its entrance to the EEC, which have otherwise experienced similar general conditions, but wich did not join the EEC. Comparisons with such a control system would complement the information obtained through the time series analysis, permitting the isolation of the changes due to menbership in the EEC and, thus, leading to more reliable conclusions.

It is not clear that the two years between the entrance of Italy to the EEC (1958) and the beginning of the second decade of study in the present vork (1960) vere sufficient for the inpact of newbership in the EBC to have begun to be measurable. Such an assumption would, of course, require empirical validation.

Purther linitations of the present study result from the unavailability of data on certain variables of interest and fros the unreliability of certain of the values reported by the data sources that could be obtained. This consideration is related to the inadequacy of data on social indicatcrs, which are a relatively recent subject of attention from both social scientists and statistics bureaus.

In spite of these limitations, the study presented in the previous chapters is a sound first step toward the understanding of the impact of nation's membership in the EEC on the quality of life of its population, and provides important information specifically on Italy. 


\subsection{A YOTE OD FOBTEER STUDI}

The present study should be conpleted in more than one way:

1) control system, consisting of one or more countries or regions with basic characteristics similar to Italy, but which did not join the EEC, should be considered and used for comparison with Italy, in order to complement the time series analysis carried out in the fresent work.

2) Data on some indicators vere not available and information on other indicators was incomplete. other data sources should be made available for completing the missing information.

3) Extensive study of other periods of time, before and after entrance to the EEC, should be considered in order to characterize the dynamics of the influence of Italy's membership in the EBC on guality of life. In particular, the delays observed in the effects relative to the entrance of the country into that international organization. 


\section{BIBLIOGRAPHI AND SOURCES}

\section{Chapter II}

1. BLAKE, B.B. and PERILLO, J.H. (editors) Busingess Regulation in the Conmon Darket Nations MCGraw-Bill Book Co., New York, 1969.

2. Collins, D. Social Policy of the European Economic community Jchn Miley \& Sons, New York, 1975.

3. HAKBAL, J., FIERO, C.E. an PIQUET, H.S. The common Market: Friend or Conpetitor? Yev York Oniversity Press, 1964.

4. WAYA, R. The Institutions of the European Compunity Chathan House, Iondon, 1968.

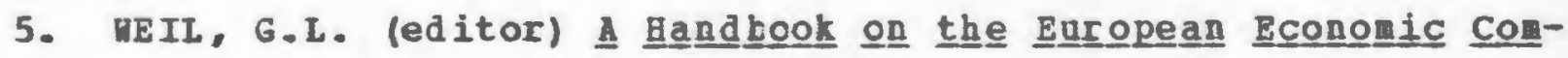
munity Frederick A. Praeger Publishers, Nex York, 1965.

6. Ireaty establishing the European Econonic Community and Connected Docunents Publishing Services of the European Commnities, 2nd edition, 1965.

\section{Chapter III}

7. DENISON, E.F. Qhy Growth Bates Differ Brookings Instituticn. Washington D.C.. 1967. 


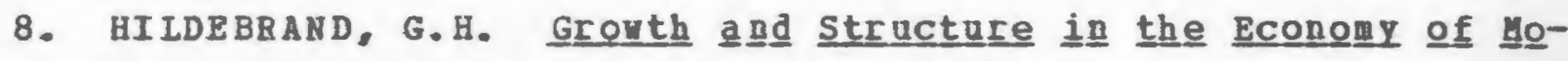
dern Italy Harvard Oniversity Press, 1965.

9. LafalombarA, J. Italy: The politics of planning syracuse University Press, 1966.

10. LoT2, 7. Italy. A Study in Economic Development oxford Oniversity Press, London, 1962.

11. MILZ, P. and BERSTEIN, S. L'Italie, la papaute, 1870-1970 Masson et Cie. Editeurs, Paris, 1970.

12. PODBIELSKI, G. Italy: Derelopment and crisis in the postUar Economy Clarendon Press, oxford, 1974.

Chapter IV

13. BAUER, R. (editor) Social Indicators MIT Press, Cambridge, 1966.

14. LAND, K.C. and SPILERHAN, S. (editors) Social Indicators Models Russell Sage Foundation, New York, 1975.

15. LI0, B.-C. Quality of Life Indicators Prager, 1976.

16. NEUPVIILE, J.F. Social Indicators and Public Policy. Interactive Processes of Design and Application Elsevier Scientific Publishing Co., Amsterdam, 1975.

17. Indicators of Environmental Quality and Quality of Life Beports and Papers in the Sccial Sciences no. 38 , Udesco, France, 1974. 
18. Indicators of Social and Econonic change and their Applications Reports and Papers in the Social Sciences no. 37 . UNESCO, France, 1977.

19. Social Indicators III. Sel Ected Data on social Conditions and Trends in the United states U.S. Department of Commerce Bureau of the Census, Nashington, 1980.

\section{Chapter I}

20. FUA, G. Notes on Italian Economic Groyth 1861-1964 E.N.I. Publicazione no. 26 della scuola Enrico Mattei di studi Superiori sigli Idrocarburi, Editore Giuffre, Milano, 1965.

8. HIALDBRAND, G.H. Growth and Structure in the Economy of 므deIn Italy Harvard University Press, Cambridge, Massachusetts, 1965.

9. MITCHELL, B.R. European Bistorical statistics 1750-1970 Colunbia University Press, New York, 1975.

10. BOSOLI, G. (editor) Un Secolo di Enigrazzione Italiana 1876-1976 Centro Studi Enigrazione, Roma, 1978.

11. SAVILIE, I. Regiona 1 Econcric Developnent Duke Jniversity Press, 1967.

12. STERN, R. Foreign Trade and Economic Grouth in Italy Praeger Publishers, New York, 1967.

13. Annuario Statistico Italiano Instituto centrale di statistica, Ministero dell'Economia Nazionale, Italy, 1948-1972. 
14. La Population de liItalie comite International de Coordination des Recherches en Demcgraphie, Nations onies, 1974.

15. The Comnon arket: ten Years on (1958-67). Statistical office of the European Commities, Brussels, 1968.

16. ㅁorla Survey on Education DNESCO, 1958, 1961, 1966, 1971. 
Appendix A

OUTPUT DESCRIPTIVE INDICATORS 
Table A.1 - OUTPUT DESCRIPTIVE INDICATORS: Indicators related to nutrition in Italy

Append1x A

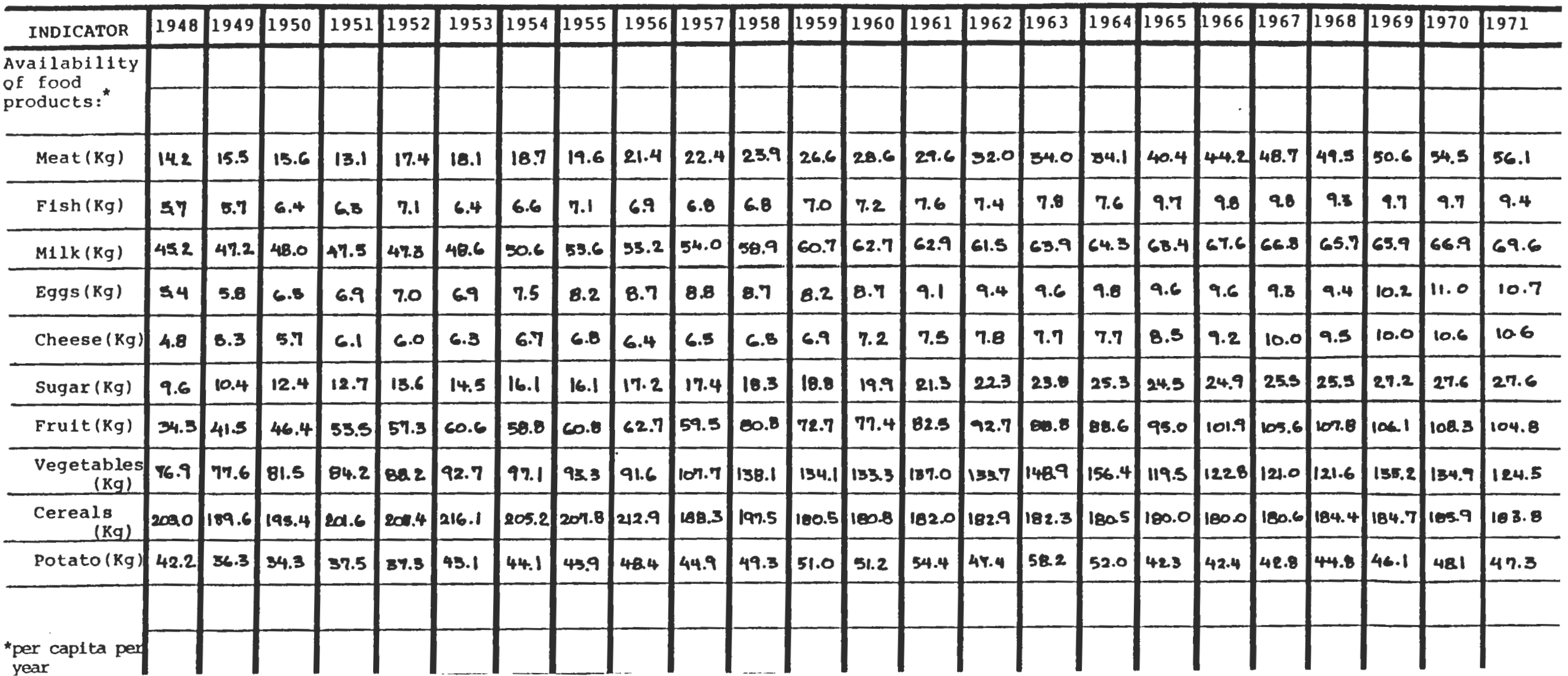

Source: Annuar1o Statist1co Italiano Instituto Centrale di statistica, Ministero dell'Economia Narionale, Italy, 1948-1972. 
Table A.l (cont.) - OUTPUT DESCRIPTIVE INDICATORS: Indicators related to nutrition in Italy

Append $1 \times$ A

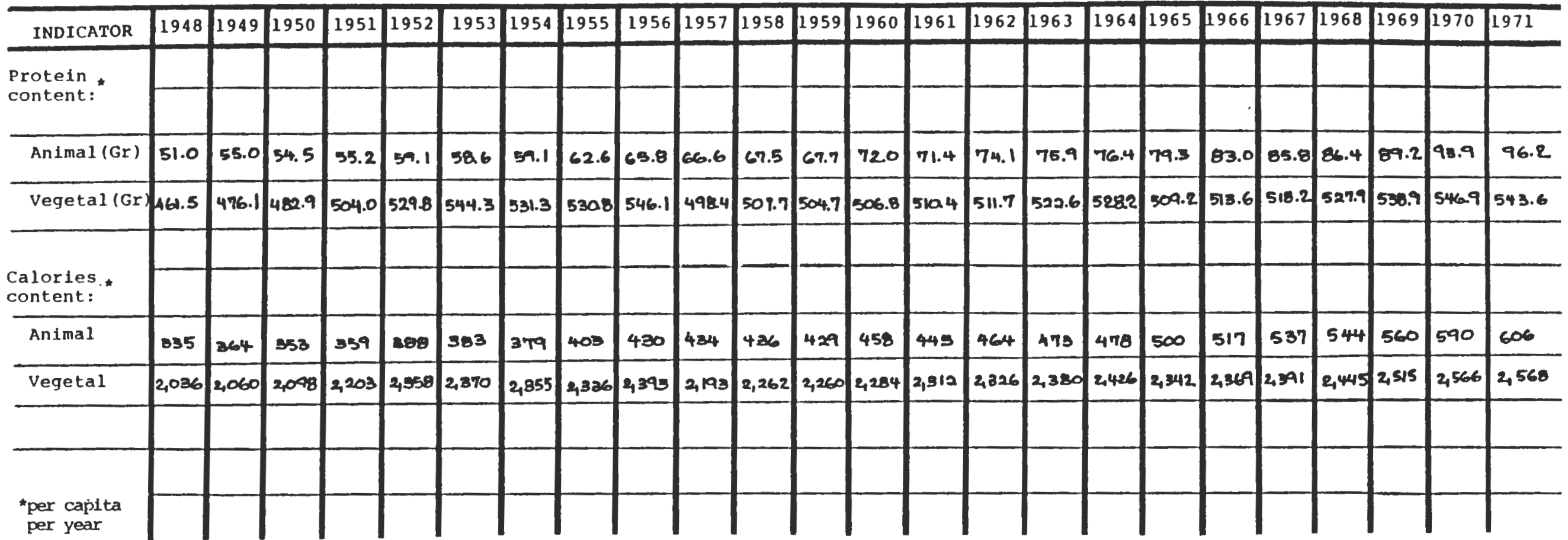


Table A.2 - OUTPUT DESCRIPTIVE INDICATORS: Indicators related to shelter in Italy

Append $1 \times A$

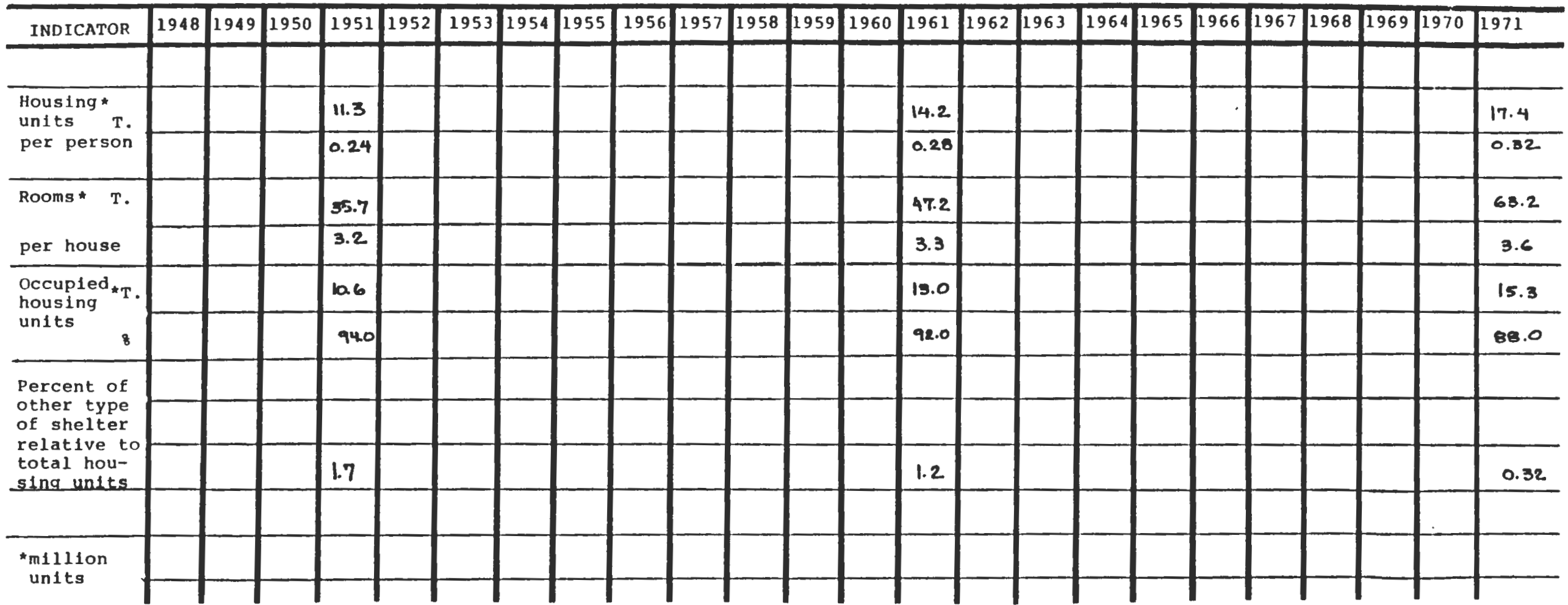

Source: Annuario Statistico Italiano Instituto Centrale al statistica, Ministero dell'Economia Nazlonalc, Italy, 1951,1961,1971. 
Table A.3 - OUTPUT DESCRIPTIVE INDICATORS: Indicators related to health in Italy

Append1X A

\begin{tabular}{|c|c|c|c|c|c|c|c|c|c|c|c|c|c|c|c|c|c|c|c|c|c|c|c|c|}
\hline INDICATOR & 1948 & 1949 & 1950 & 1951 & 1952 & 1953 & 1954 & 1955 & 1956 & 1957 & 1958 & 1959 & 1960 & 1961 & 1962 & 1963 & 1964 & 1965 & 1966 & 1967 & 1968 & 1969 & 1970 & 1971 \\
\hline $\begin{array}{l}\text { Mean age of } \\
\text { death } 11)\end{array}$ & - & 53.0 & 53.0 & - & 68.2 & 68.9 & 68.4 & - & - & 69.4 & 696 & - & 70.4 & 70.4 & 70.9 & 70.9 & 70.8 & - & - & 71.7 & 72.1 & 71.6 & 71.8 & - \\
\hline $\begin{array}{l}\text { Total mortal } 1 \\
\text { ty rate * }(2)\end{array}$ & 10.4 & 10.5 & 9.8 & 10.3 & 10.0 & 9.9 & 9.1 & 8.6 & 7.6 & 8.0 & 9.8 & 9.1 & 9.6 & 9.3 & 10.0 & - & - & 9.8 & 9.3 & 9.5 & 9.9 & 9.9 & 7.5 & a.s \\
\hline $\begin{array}{l}\text { Infant morta- } \\
\text { lity rate } \$(2)\end{array}$ & 72 & 74 & 64 & 67 & 63 & 50 & 53 & 51 & 5 & 50 & 48 & 45 & 44 & 41 & 42 & 40 & 36 & 36 & 35 & 33 & $\$ 2$ & 30 & 29 & 28 \\
\hline $\begin{array}{l}\text { Disease } \\
\text { rate: * (1) }\end{array}$ & & & & & & & & & & & & & & & & & & & & & & & & \\
\hline Epidemic ${ }_{r}^{T}$ & $\begin{array}{l}47.792 \\
1.0\end{array}$ & $\begin{array}{c}4,371 \\
0.9\end{array}$ & $\begin{array}{c}32,103 \\
0.7\end{array}$ & - & $\begin{array}{c}24.655 \\
0.5\end{array}$ & $\begin{array}{c}19.249 \\
0.4\end{array}$ & $\begin{array}{l}10,424 \\
04\end{array}$ & $\begin{array}{l}17.57 \\
0.4\end{array}$ & $\begin{array}{c}17,307 \\
0.4\end{array}$ & $\begin{array}{l}16.702 \\
0.3\end{array}$ & $\begin{array}{l}16,45 \\
0.8\end{array}$ & - & $\begin{array}{c}13,000 \\
0.1\end{array}$ & $\begin{array}{l}18,007 \\
0.3\end{array}$ & $\begin{array}{l}\text { किजकव } \\
0.3\end{array}$ & $\begin{array}{c}\bar{n}, 47 \\
0.2\end{array}$ & $\begin{array}{l}0.0 .40 \\
0.2\end{array}$ & - & $\begin{array}{l}80.2 \\
0.2\end{array}$ & $\begin{array}{l}9.134 \\
0.2\end{array}$ & $\begin{array}{l}11,200 \\
0.2\end{array}$ & $\begin{array}{c}10,362 \\
0.2\end{array}$ & $\begin{array}{c}9.511 \\
0.2\end{array}$ & $\begin{array}{l}0,338 \\
0.2\end{array}$ \\
\hline Tumors & $\begin{array}{l}38000 \\
1.0\end{array}$ & $\begin{array}{c}90,104 \\
4\end{array}$ & $\begin{array}{c}32,578 \\
1.1 \\
\end{array}$ & 一 & $\begin{array}{c}n, 500 \\
1.2\end{array}$ & $\begin{array}{c}10,560 \\
1.3\end{array}$ & $\begin{array}{c}62,220 \\
1.3\end{array}$ & $\begin{array}{c}64,644 \\
1.3 \\
\end{array}$ & $\begin{array}{c}67,641 \\
1.4 \\
\end{array}$ & $\begin{array}{c}5,460 \\
1.4\end{array}$ & $\begin{array}{c}70,804 \\
1.4\end{array}$ & & $\begin{array}{c}76,915 \\
1.5\end{array}$ & $\begin{array}{l}4,119 \\
1.6 \\
\end{array}$ & $\begin{array}{c}81,05 \\
1.6 \\
\end{array}$ & $\begin{array}{c}8,805 \\
1.7 \\
\end{array}$ & $\begin{array}{c}8,011 \\
1.7\end{array}$ & 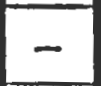 & $\begin{array}{l}8,793 \\
1.7\end{array}$ & $\begin{array}{c}12,147 \\
1.0\end{array}$ & $\begin{array}{c}95,242 \\
1.8\end{array}$ & $\begin{array}{c}7,102 \\
19\end{array}$ & $\begin{array}{c}\text { क, } 260 \\
1.9\end{array}$ & $\begin{array}{l}101,743 \\
1.9\end{array}$ \\
\hline circulatory & $\begin{array}{l}96,410 \\
21\end{array}$ & $\begin{array}{c}4.94 \\
E .1\end{array}$ & $\begin{array}{c}93,745 \\
2.0\end{array}$ & - & $\begin{array}{c}16,213 \\
24\end{array}$ & $\begin{array}{c}12 \pi, 3 \pi \\
26\end{array}$ & $\begin{array}{c}118,900 \\
2.5\end{array}$ & $\begin{array}{c}122,233 \\
2.5\end{array}$ & $\begin{array}{c}14452 \\
30\end{array}$ & $\begin{array}{c}140,213 \\
29\end{array}$ & $\begin{array}{c}\text { 132.64 } \\
2.7\end{array}$ & & $\begin{array}{c}144,424 \\
29\end{array}$ & $\begin{array}{c}142720 \\
2.9 \\
\end{array}$ & $\begin{array}{c}160, \sqrt{16} \\
2.2\end{array}$ & $\begin{array}{l}16545 \\
3.2\end{array}$ & $\begin{array}{c}15 \times p+7 \\
20\end{array}$ & & $\begin{array}{c}15.745 \\
3.0\end{array}$ & $\begin{array}{c}\text { जि, की } \\
21\end{array}$ & $\begin{array}{c}201,631 \\
47\end{array}$ & $\begin{array}{c}2,5,530 \\
4.6\end{array}$ & $\begin{array}{l}235,372 \\
4.4\end{array}$ & $\begin{array}{c}236.36 \\
4.4\end{array}$ \\
\hline Respirator ${ }^{\mathrm{T}}$ & $\begin{array}{c}64,0234 \\
1.4\end{array}$ & $\begin{array}{c}5,759 \\
13\end{array}$ & $\begin{array}{c}n+182 \\
1.0\end{array}$ & - & $\begin{array}{c}45,404 \\
2.0\end{array}$ & $\begin{array}{c}\text { Pi.2य } \\
1.0\end{array}$ & $\begin{array}{l}36,266 \\
a, B\end{array}$ & $\begin{array}{c}30,133 \\
0.0\end{array}$ & $\begin{array}{c}00,343 \\
10\end{array}$ & $\begin{array}{c}76,425 \\
0.9\end{array}$ & $\begin{array}{l}58.841 \\
0.8\end{array}$ & & $\begin{array}{l}\text { 4.5.65 } \\
\text { OA }\end{array}$ & $\begin{array}{c}56,675 \\
0.7\end{array}$ & $\begin{array}{c}46,714 \\
0.9\end{array}$ & $\begin{array}{l}46.916 \\
0.9\end{array}$ & $\begin{array}{l}0.116 \\
0.7\end{array}$ & & $\begin{array}{l}34,176 \\
0.7\end{array}$ & $\begin{array}{c}0,821 \\
0.0\end{array}$ & $\begin{array}{c}32,414 \\
1.0\end{array}$ & $\begin{array}{c}x, 7 \times a \\
1.1\end{array}$ & $\begin{array}{l}50,595 \\
09\end{array}$ & $\begin{array}{l}94.426 \\
0.7 \\
\end{array}$ \\
\hline $\begin{array}{l}* \text { Per } 1,000 \\
6 \text { Per } 1,000\end{array}$ & $\begin{array}{l}\text { habit } \\
\text { live }\end{array}$ & nts & & & $\begin{array}{ll}T & \text { Tot } \\
x & \text { Rat }\end{array}$ & & & & & & & & & & & & & & & & & & & \\
\hline
\end{tabular}

Source: (1) Annuarlo Statistico Italiano Instituto Centrale di Statistica, Ministero dell'Economia Nazionale, Italy, 1948-1972.

(2) Mitchell, B.R. European Historical Statistics 1750-1970 Columbia University Press, New York,1967. 
Table A.4 - OUTPUT DESCRIPTIVE INDICATORS: Indicators related to safety in Italy

Appendix A

\begin{tabular}{|c|c|c|c|c|c|c|c|c|c|c|c|c|c|c|c|c|c|c|c|c|c|c|c|c|}
\hline INDICATOR & 1948 & 1949 & 1950 & 1951 & 1952 & 1953 & 1954 & 1955 & 1956 & 1957 & 1958 & 1959 & 1960 & 1961 & 1962 & 1963 & 1964 & 1965 & 1966 & 1967 & 1968 & 1969 & 1970 & 1971 \\
\hline $\begin{array}{l}\text { Accidents } \\
\text { leading to }\end{array}$ & & & & & & & & & & & & & & & & & & & & & & & & \\
\hline $\begin{array}{ll}\text { Traffic } & \text { T } \\
& \text { r }\end{array}$ & $\begin{array}{c}4,056 \\
8,6\end{array}$ & $\begin{array}{l}4,295 \\
91,4\end{array}$ & $\begin{array}{l}5,114 \\
100.1\end{array}$ & $\begin{array}{l}1662 \\
119.6 \\
\end{array}$ & $\begin{array}{l}6,420 \\
134.7\end{array}$ & $\begin{array}{l}7,237 \\
150.8 \\
\end{array}$ & $\begin{array}{l}8,064 \\
167.3\end{array}$ & $\begin{array}{l}9,149 \\
10.26\end{array}$ & $\begin{array}{l}8,912 \\
182.6 \\
\end{array}$ & $\begin{array}{l}9,144 \\
147.0\end{array}$ & $\begin{array}{l}9.205 \\
187.1\end{array}$ & $\begin{array}{l}9,019 \\
162.2\end{array}$ & $\begin{array}{l}9,609 \\
194.9\end{array}$ & $\begin{array}{l}212,651 \\
212.0\end{array}$ & $\begin{array}{l}11.093 \\
232.5\end{array}$ & $\begin{array}{l}12150 \\
2402\end{array}$ & $\begin{array}{l}12,266 \\
2400\end{array}$ & $\begin{array}{l}11,651 \\
223.0\end{array}$ & $\begin{array}{l}11,528 \\
24,6\end{array}$ & $\begin{array}{l}12,110 \\
221.5\end{array}$ & $\begin{array}{l}12,304 \\
235.0\end{array}$ & $\begin{array}{l}12,916 \\
245.0\end{array}$ & $\begin{array}{l}13,774 \\
258.0\end{array}$ & $=$ \\
\hline $\begin{array}{r}\text { Homlcides } \\
\mathrm{r}\end{array}$ & $\begin{array}{l}1,084 \\
23.2\end{array}$ & $\begin{array}{l}807 \\
17.2\end{array}$ & $\begin{array}{l}767 \\
16.2\end{array}$ & $\begin{array}{l}6.91 \\
14.5\end{array}$ & $\begin{array}{l}690 \\
14.5\end{array}$ & $\begin{array}{l}654 \\
13.6 \\
\end{array}$ & $\begin{array}{l}566 \\
13.8\end{array}$ & $\begin{array}{l}7 ! 4 \\
1+7\end{array}$ & $\begin{array}{l}753 \\
15.5 \\
\end{array}$ & $\begin{array}{l}675 \\
13.8 \\
\end{array}$ & $\begin{array}{l}472 \\
13.7\end{array}$ & $\begin{array}{l}614 \\
12.4 \\
\end{array}$ & $\begin{array}{l}655 \\
13.2 \\
\end{array}$ & \begin{tabular}{|l|}
513 \\
11.5 \\
\end{tabular} & $\begin{array}{l}498 \\
9.9 \\
\end{array}$ & $\begin{array}{l}481 \\
9.6 \\
\end{array}$ & $\begin{array}{l}451 \\
8.8 \\
\end{array}$ & $\begin{array}{l}460 \\
9.0\end{array}$ & $\begin{array}{r}424 \\
8.2 \\
\end{array}$ & $\begin{array}{r}481 \\
9.2 \\
\end{array}$ & $\begin{array}{l}469 \\
8.9 \\
\end{array}$ & $\begin{array}{c}448 \\
8.5 \\
\end{array}$ & $\begin{array}{r}447 \\
8.4 \\
\end{array}$ & \\
\hline other & $\begin{array}{l}13,327 \\
269.7 \\
\end{array}$ & $\begin{array}{l}15,450 \\
286.2\end{array}$ & $\begin{array}{l}16,400 \\
308.8\end{array}$ & $\begin{array}{l}19,409 \\
224.4\end{array}$ & $\begin{array}{l}15,968 \\
324.8\end{array}$ & $\begin{array}{l}15,721 \\
327.5\end{array}$ & $\begin{array}{l}16,749 \\
347.5\end{array}$ & $\begin{array}{l}17,944 \\
370.0\end{array}$ & $\begin{array}{l}18,638 \\
381,7\end{array}$ & $\begin{array}{l}19,203 \\
392.1 \\
\end{array}$ & $\begin{array}{l}7,070 \\
301.0\end{array}$ & $\begin{array}{l}10,110 \\
204,4\end{array}$ & $\begin{array}{l}10,547 \\
212.3 \\
\end{array}$ & \begin{tabular}{|l|}
11,638 \\
232.8 \\
\end{tabular} & $\begin{array}{l}11,183 \\
222.3\end{array}$ & $\begin{array}{l}13,839 \\
264\end{array}$ & $\begin{array}{l}10,940 \\
224.1\end{array}$ & $\begin{array}{l}11,127 \\
24.7\end{array}$ & $\begin{array}{l}9000 \\
207.8 \\
\end{array}$ & $\begin{array}{l}\pi 224 \\
215.8\end{array}$ & $\begin{array}{l}71,967 \\
217.6\end{array}$ & $\begin{array}{l}11,506 \\
277.0\end{array}$ & $\begin{array}{l}11,535 \\
216.0\end{array}$ & $=$ \\
\hline $\begin{array}{l}\text { Robberles } \\
\text { reported to? }\end{array}$ & $=$ & 二 & $=$ & $=$ & $=$ & $=$ & $=$ & 219649 & 233,001 & 23ypas & 227,104 & 200,544 & 242,768 & 204,013 & 24y/75 & 260,152 & $213 / 79$ & $2 n 1,42$ & 250,152 & 254715 & 271,240 & $277,3 \times d$ & 343,476 & 400,327 \\
\hline the pollce ${ }^{\mathrm{r}}$ & - & - & 一 & $\longrightarrow$ & & $=$ & $=$ & 4,343 & 4,284 & 7,217 & 4,640 & 4,657 & 4,005 & 4.82 & 4,684 & 5,181 & 5,204 & 4,679 & 9,811 & 1.902 & 5,147 & 5,284 & 6,432 & 7,604 \\
\hline
\end{tabular}

* Per 1,000,000 habitant. $\begin{aligned} & \text { T Total } \\ & \text { r Rate }\end{aligned}$

Source: Annuar1o Stat1st1co Itallano Instituto Centrale di Stat1stica, Ministero dell'Economia Nazionale, Italy, 19 48-1972. 
Table A.5 - OUTPUT DESCRIPTIVE INDICATORS: Indicators related to education in Italy

\begin{tabular}{|c|c|c|c|c|c|c|c|c|c|c|c|c|c|c|c|c|c|c|c|c|c|c|c|c|}
\hline INDICATOR & 1948 & 1949 & 1950 & 1951 & 1952 & 1953 & 1954 & 1955 & 1956 & 1957 & 1958 & 1959 & 1960 & 1961 & 1962 & 1963 & 1964 & 1965 & 1966 & 1967 & 1968 & 1969 & 1970 & 1971 \\
\hline $\begin{array}{l}\text { Percent of } \\
\text { illeterates }\end{array}$ & & & & 5,454 & & & & & & & & & & S.797 & & & & & & & & & & \\
\hline $\begin{array}{l}(6 \text { yrs old } \\
\text { and over) }\end{array}$ & & & & 12.9 & & & & & & & & & & 0.3 & & & & & & & & & & 5.2 \\
\hline \multirow{2}{*}{\multicolumn{25}{|c|}{$\begin{array}{l}\text { Percent of } \\
\text { school age } \\
\text { population } \\
\text { enrolled: }\end{array}$}} \\
\hline & & & & & & & & & & & & & & & & & & & & & & & & \\
\hline $\begin{array}{l}\text { Elementary } \\
\text { + Secondary }\end{array}$ & & & & 80.2 & & & & & & & & & & 90.4 & & & & & & & & & & 102.4 \\
\hline Advanced & & & & 10.6 & & & & & & & & & & 21.6 & & & & & & & & & & 43.7 \\
\hline Untversity & & & & 5.6 & & & & & & & & & & 7.1 & & & & & & & & & & 19.0 \\
\hline \multicolumn{25}{|l|}{$\begin{array}{l}\text { Puptls per } \\
\text { teacher: }\end{array}$} \\
\hline Prtmary & 29.5 & 26.7 & 27.3 & 26.1 & 25.9 & 25.7 & 264 & 26.8 & 26.2 & 25.1 & 24.4 & 22.8 & 221 & 22.0 & 21.4 & 21.6 & 21.7 & 21.8 & 21.7 & 21.7 & 21.6 & 21.9 & 21.8 & \\
\hline Secondary & 10.6 & 10.0 & 10.4 & 10.6 & 11.2 & 11.8 & 11.6 & 11.7 & 11.0 & 12.6 & 12.6 & 12.5 & 12.0 & 11.6 & 11.5 & 11.5 & 11.5 & 11.6 & 11.4 & 114 & 11.5 & 11.6 & 11.0 & \\
\hline
\end{tabular}
Source: Annuario Stat1st1co Ital1ano Inst1tuto Centrale di stat1stica, Ministero dell'Economia Naz1onale, 
Table A.6 - OUTPUT DESCRIPTIVE INDICATORS: Indicators related to communication in Italy

Appendix $A$

\begin{tabular}{|c|c|c|c|c|c|c|c|c|c|c|c|c|c|c|c|c|c|c|c|c|c|c|c|c|}
\hline INDICATOR & 1948 & 1949 & 1950 & 1951 & 1952 & 1953 & 1954 & 1955 & 1956 & 1957 & 1958 & 1.959 & 1960 & 1961 & 1962 & 1963 & 1964 & 1965 & 1966 & 1967 & 1968 & 1969 & 1970 & 1971 \\
\hline \multicolumn{25}{|c|}{$\begin{array}{l}\text { Number of mo } \\
\text { ter vehicles }\end{array}$} \\
\hline PC & $\begin{array}{r}219 \\
4.7 \\
\end{array}$ & $\begin{array}{c}267 \\
5.7 \\
\end{array}$ & $\begin{array}{l}342 \\
7.2 \\
\end{array}$ & $\begin{array}{l}425 \\
8.9 \\
\end{array}$ & $\begin{array}{l}510 \\
10.7 \\
\end{array}$ & $\begin{array}{l}613 \\
12.8 \\
\end{array}$ & $\begin{array}{r}744 \\
154 \\
\end{array}$ & $\begin{array}{l}879 \\
18.1 \\
\end{array}$ & $\begin{array}{l}1,031 \\
21.2\end{array}$ & $\begin{array}{l}1,231 \\
25.2 \\
\end{array}$ & $\begin{array}{l}1,393 \\
28.3 \\
\end{array}$ & $\begin{array}{l}6644 \\
33.2\end{array}$ & $\begin{array}{l}1,995 \\
40.1 \\
\end{array}$ & $\begin{array}{c}2,444 \\
48.9 \\
\end{array}$ & $\begin{array}{l}3,030 \\
60.2 \\
\end{array}$ & $\begin{array}{l}3,913 \\
77.2 \\
\end{array}$ & $\begin{array}{l}4,675 \\
91.5 \\
\end{array}$ & $\begin{array}{l}5,473 \\
106.1 \\
\end{array}$ & $\begin{array}{l}6.357 \\
122.3 \\
\end{array}$ & $\begin{array}{l}7,311 \\
139.8 \\
\end{array}$ & $\begin{array}{l}8,266 \\
156.9\end{array}$ & $\begin{array}{l}9,174 \\
173.1 \\
\end{array}$ & $\begin{array}{l}19181 \\
190.1\end{array}$ & $\begin{array}{l}11,299 \\
210.4\end{array}$ \\
\hline $\mathrm{CV}$ & $\begin{array}{l}196 \\
4.2 \\
\end{array}$ & $\begin{array}{l}214 \\
4.6 \\
\end{array}$ & $\begin{array}{l}229 \\
4.8 \\
\end{array}$ & $\begin{array}{r}249 \\
5.2 \\
\end{array}$ & $\begin{array}{l}274 \\
5.7 \\
\end{array}$ & $\begin{array}{l}805 \\
6.4 \\
\end{array}$ & $\begin{array}{l}339 \\
10 \\
\end{array}$ & $\begin{array}{l}367 \\
7.6\end{array}$ & $\begin{array}{c}360 \\
7.4 \\
\end{array}$ & $\begin{array}{l}373 \\
7.6 \\
\end{array}$ & $\begin{array}{c}385 \\
7.8 \\
\end{array}$ & $\begin{array}{l}426 \\
8.6 \\
\end{array}$ & $\begin{array}{l}456 \\
9.2 \\
\end{array}$ & $\begin{array}{l}4.99 \\
9.8 \\
\end{array}$ & $\begin{array}{l}530 \\
10.7 \\
\end{array}$ & \begin{tabular}{|l|}
596 \\
11.8 \\
\end{tabular} & $\begin{array}{l}680 \\
12.3 \\
\end{array}$ & \begin{tabular}{|l|}
650 \\
12.6 \\
\end{tabular} & $\begin{array}{l}684 \\
13.2 \\
\end{array}$ & $\begin{array}{l}718 \\
13.7 \\
\end{array}$ & $\begin{array}{l}793 \\
15.0 \\
\end{array}$ & $\begin{array}{l}798 \\
15.0 \\
\end{array}$ & $\begin{array}{l}904 \\
16.9 \\
\end{array}$ & $\begin{array}{l}972 \\
18.1 \\
\end{array}$ \\
\hline $\begin{array}{l}\text { Total length } \\
\text { efmetorway }\end{array}$ & 170,500 & M1, 150 & mabs? & 10,162 & Mals3 & 170,011 & 174,202 & 175,175 & 176,948 & 101,010 & 181,055 & 181,582 & 191,746 & $\mid 9 \%, 229$ & 193,246 & (195, 127) & mestia & - & - & 286445 & 283,596 & 25,130 & 20438 & 206,996 \\
\hline $\begin{array}{l}\text { Total length } \\
\text { of railway }\end{array}$ & 21,349 & 21,639 & 21,550 & 20,711 & 2,743 & en,822 & 21,62 & 21,923 & 21,723 & 23,584 & 21,516 & 2,30 & 21,277 & 21,143 & 20,972 & 24,014 & 29805 & $\mid \infty, 012$ & $29=1$ & 20,566 & 20,358 & 29201 & 20,212 & 20,239 \\
\hline \multicolumn{25}{|c|}{$\begin{array}{l}\text { Rallway bas } \\
\text { senger } \\
\text { traffic: }\end{array}$} \\
\hline $\begin{array}{l}\text { traffic: } \\
\text { passenger per } \\
\text { capita }\end{array}$ & $\begin{array}{c}544.6 \\
11.7 \\
\end{array}$ & $\begin{array}{l}540 \\
10.9\end{array}$ & $\begin{array}{c}327.1 \\
11.1 \\
\end{array}$ & $\begin{array}{c}522.3 \\
11.0\end{array}$ & $\begin{array}{c}537.8 \\
11.3\end{array}$ & $\begin{array}{c}557.4 \\
11.6\end{array}$ & $\begin{array}{l}536.5 \\
11.5 \\
\end{array}$ & $\begin{array}{c}564.8 \\
11.6 \\
\end{array}$ & $\begin{array}{l}59.5 \\
11.5 \\
\end{array}$ & $\begin{array}{l}531.5 \\
10.9 \\
\end{array}$ & $\begin{array}{c}538.1 \\
11.0 \\
\end{array}$ & $\begin{array}{l}5396 \\
10.9 \\
\end{array}$ & $\begin{array}{l}574.4 \\
11.6\end{array}$ & $\begin{array}{c}542.5 \\
10.9 \\
\end{array}$ & $\begin{array}{c}525.4 \\
10.4 \\
\end{array}$ & $\begin{array}{l}503.5 \\
10.0 \\
\end{array}$ & $\begin{array}{c}471.7 \\
9.2 \\
\end{array}$ & $\begin{array}{c}448.7 \\
0.7 \\
\end{array}$ & $\begin{array}{c}444.8 \\
8.5 \\
\end{array}$ & $\begin{array}{c}446.4 \\
8.5 \\
\end{array}$ & $\begin{array}{c}446.1 \\
05\end{array}$ & $\begin{array}{c}4004.0 \\
8.4 \\
\end{array}$ & $\begin{array}{c}456.0 \\
2.5\end{array}$ & 462.5 \\
\hline $\begin{array}{l}\text { passenger. } \mathrm{Km} \\
\text { per capita }\end{array}$ & $\begin{array}{l}26,594 \\
569.5 \\
\end{array}$ & $\begin{array}{l}28350 \\
5024 \\
\end{array}$ & $\begin{array}{l}22,578 \\
498,5\end{array}$ & $\begin{array}{l}24,476 \\
515.3 \\
\end{array}$ & $\begin{array}{l}25,107 \\
5 \times, 4\end{array}$ & $\begin{array}{c}25,784 \\
587.2 \\
\end{array}$ & $\begin{array}{l}24,688 \\
56.3 \\
\end{array}$ & $\begin{array}{l}26,071 \\
537.5 \\
\end{array}$ & $\begin{array}{r}27,711 \\
569.0 \\
\end{array}$ & $\begin{array}{l}28,114 \\
585.0 \\
\end{array}$ & $\begin{array}{l}28.867 \\
586.0 \\
\end{array}$ & $\begin{array}{l}28,953 \\
505.0 \\
\end{array}$ & $\begin{array}{l}2972.3 \\
618.2 \\
\end{array}$ & $\begin{array}{l}34,449 \\
629,0 \\
\end{array}$ & $\begin{array}{l}31,45 \\
025.5 \\
\end{array}$ & $\begin{array}{l}32,026 \\
631.7 \\
\end{array}$ & $\begin{array}{l}29617 \\
549.2 \\
\end{array}$ & $\begin{array}{l}29,024 \\
5627\end{array}$ & $\begin{array}{l}29,004 \\
574.1\end{array}$ & $\begin{array}{l}30,105 \\
581.0\end{array}$ & $\begin{array}{l}31,011 \\
594.1 \\
\end{array}$ & $\begin{array}{l}36946 \\
602.8 \\
\end{array}$ & $\begin{array}{l}34764 \\
647.4 \\
\end{array}$ & \\
\hline $\begin{array}{l}\text { Number of } \\
\text { telephones }\end{array}$ & $\begin{array}{l}2 \div 0 \\
19.2 \\
\end{array}$ & $\begin{array}{l}: 4: 1 \\
19.6\end{array}$ & $\begin{array}{l}1,041 \\
22.0 \\
\end{array}$ & $\begin{array}{l}1,159 \\
24.4 \\
\end{array}$ & $\begin{array}{l}1,296 \\
27.2 \\
\end{array}$ & $\begin{array}{r}1,508 \\
31,4 \\
\end{array}$ & $\begin{array}{l}1,764 \\
36.6 \\
\end{array}$ & $\begin{array}{l}4,004 \\
41.3 \\
\end{array}$ & & & $\begin{array}{l}2,718 \\
55.2 \\
\end{array}$ & $\begin{array}{l}3,044 \\
61.5\end{array}$ & $\begin{array}{l}3,379 \\
68,0\end{array}$ & $\begin{array}{r}3,717 \\
74.3 \\
\end{array}$ & $\begin{array}{l}4,41 \\
80.3 \\
\end{array}$ & $\begin{array}{l}4,201 \\
84.4 \\
\end{array}$ & $\begin{array}{l}4,636 \\
90.7 \\
\end{array}$ & $\begin{array}{r}5,015 \\
17.2 \\
\end{array}$ & $\begin{array}{l}5423 \\
104.3 \\
\end{array}$ & $\begin{array}{l}5,786 \\
110.6 \\
\end{array}$ & $\begin{array}{l}6,149 \\
116.7 \\
\end{array}$ & $\begin{array}{l}4525 \\
123.1 \\
\end{array}$ & $\begin{array}{l}6,961 \\
130.4 \\
\end{array}$ & $\begin{array}{l}7.502 \\
139.7 \\
\end{array}$ \\
\hline $\begin{array}{l}\text { Number of } \\
\text { phone calls }\end{array}$ & $\begin{array}{l}81.1 \\
0.17 \\
\end{array}$ & $\begin{array}{l}87.5 \\
0.19 \\
\end{array}$ & $\begin{array}{l}101 \\
0.21 \\
\end{array}$ & $\begin{array}{l}121 \\
0.25 \\
\end{array}$ & $\begin{array}{l}14.3 \\
0.20 \\
\end{array}$ & $\begin{array}{l}164 \\
0.34 \\
\end{array}$ & $\begin{array}{l}193 \\
0.40 \\
\end{array}$ & $\begin{array}{l}206 \\
0.42 \\
\end{array}$ & $\begin{array}{l}239 \\
0.49\end{array}$ & $\begin{array}{l}307 \\
0.62 \\
\end{array}$ & $\begin{array}{l}349 \\
0.71 \\
\end{array}$ & $\begin{array}{l}402 \\
0.01 \\
\end{array}$ & $\begin{array}{l}445 \\
0.90 \\
\end{array}$ & $\begin{array}{l}517 \\
1.03 \\
\end{array}$ & $\begin{array}{l}603 \\
1.20 \\
\end{array}$ & $\begin{array}{l}716 \\
1.41 \\
\end{array}$ & $\begin{array}{l}787 \\
1.54 \\
\end{array}$ & \begin{tabular}{|l|}
068 \\
1.68 \\
\end{tabular} & $\begin{array}{l}936 \\
1.80 \\
\end{array}$ & $\begin{array}{r}1,070 \\
2.05 \\
\end{array}$ & $\begin{array}{l}1.185 \\
2.25 \\
\end{array}$ & $\begin{array}{r}1,980 \\
2.60 \\
\end{array}$ & $\begin{array}{l}1,609 \\
3.01 \\
\end{array}$ & $\begin{array}{r}1.839 \\
3.42 \\
\end{array}$ \\
\hline $\begin{array}{l}\text { Number of } \\
\text { letterst }\end{array}$ & $\begin{array}{l}2,651 \\
56.8 \\
\end{array}$ & $\begin{array}{l}4617 \\
55.7 \\
\end{array}$ & $\begin{array}{l}2.797 \\
59.1 \\
\end{array}$ & $\begin{array}{l}3,054 \\
64.3 \\
\end{array}$ & $\begin{array}{l}3.185 \\
6.8 \\
\end{array}$ & $\begin{array}{l}3,423 \\
71.3\end{array}$ & $\begin{array}{l}3,565 \\
74.0 \\
\end{array}$ & $\begin{array}{l}3,876 \\
800\end{array}$ & $\begin{array}{l}4,319 \\
80.1\end{array}$ & $\begin{array}{l}4,648 \\
95.1 \\
\end{array}$ & $\begin{array}{l}4.834 \\
92.3 \\
\end{array}$ & $\begin{array}{l}4,867 \\
78.3 \\
\end{array}$ & $\begin{array}{l}5,147 \\
1036 \\
\end{array}$ & $\begin{array}{l}3,116 \\
1023\end{array}$ & $\begin{array}{l}5,292 \\
105.2 \\
\end{array}$ & $\begin{array}{l}5,664 \\
1126\end{array}$ & - & $\begin{array}{l}5,600 \\
108.5\end{array}$ & $\begin{array}{l}5.850 \\
112.5 \\
12\end{array}$ & $\begin{array}{l}5,923 \\
113.3 \\
\end{array}$ & $\begin{array}{l}5.936 \\
112.6 \\
\end{array}$ & $\begin{array}{l}6.292 \\
118.7 \\
\end{array}$ & $\begin{array}{l}6.356 \\
119.0 \\
\end{array}$ & $\begin{array}{l}6.267 \\
116.7 \\
\end{array}$ \\
\hline $\begin{array}{l}\text { Number of }+ \\
\text { telegrams }\end{array}$ & $\begin{array}{l}26.0 \\
0.6\end{array}$ & $\begin{array}{l}28.1 \\
0.6\end{array}$ & $\begin{array}{l}30.2 \\
0.6\end{array}$ & $\begin{array}{l}2.4 .4 \\
0.6\end{array}$ & $\begin{array}{l}29.7 \\
0.6\end{array}$ & $\begin{array}{c}30.4 \\
0.6\end{array}$ & $\begin{array}{l}2.2 .2 \\
0.7\end{array}$ & $\begin{array}{l}34.4 \\
0.7\end{array}$ & $\begin{array}{l}35.1 \\
0.7\end{array}$ & $\begin{array}{c}34.4 \\
0.7\end{array}$ & $\begin{array}{l}33.0 \\
0.7 \\
\end{array}$ & $\begin{array}{l}38.5 \\
0.7\end{array}$ & $\begin{array}{c}34.5 \\
0.7 \\
\end{array}$ & $\begin{array}{l}6.4 \\
0.7 \\
\end{array}$ & $\begin{array}{l}39.3 \\
0.8\end{array}$ & $\begin{array}{l}40.9 \\
0.8\end{array}$ & & $\begin{array}{l}37.5 \\
0.7 \\
\end{array}$ & $\begin{array}{c}31.8 \\
0.6\end{array}$ & $\begin{array}{l}29.0 \\
0.6\end{array}$ & $\begin{array}{l}26-4 \\
0.5\end{array}$ & $\begin{array}{l}24 \\
05\end{array}$ & $\begin{array}{c}25.9 \\
0.5 \\
\end{array}$ & $\begin{array}{l}25.2 \\
0.5\end{array}$ \\
\hline
\end{tabular}

- per 1,000,000 habitant

6 kilometers

Qper 1,000 hab1tants

+ per 1,000,000 habitants Source: Mitche11, B.R. European H1storical Stat1st1ca 1750-1970

Columbia University Press, New York, 1975 . 
Table A.7 - OUTPUT DESCRIPTIVE INDICATORS: Indicators related to culture in Italy

Appendix A

\begin{tabular}{|c|c|c|c|c|c|c|c|c|c|c|c|c|c|c|c|c|c|c|c|c|c|c|c|c|}
\hline INDICATOR & 1948 & 1949 & 1950 & 1951 & 1952 & 1953 & 1954 & 1955 & 1956 & 1957 & 1958 & 1959 & 1960 & 1961 & 1962 & 1963 & 1964 & 1965 & 1966 & 1967 & 1968 & 1969 & $19 \%$ & 1971 \\
\hline Visłts to: & & & & & & & & & & & & & & & & & & & & & & & & \\
\hline $\begin{array}{l}\text { Museum } \\
\text { per 1,000 hab. }\end{array}$ & & & & & & & & $\begin{array}{l}1,381 \\
28.5\end{array}$ & & & & $\begin{array}{l}1.553 \\
31.4 \\
\end{array}$ & & & $\begin{array}{l}1740 \\
84.6\end{array}$ & & $\begin{array}{l}4.107 \\
41.2\end{array}$ & $\begin{array}{l}2160 \\
41.9\end{array}$ & & & & $\begin{array}{l}24400 \\
46.7\end{array}$ & & $\begin{array}{r}2,454 \\
45.7 \\
\end{array}$ \\
\hline $\begin{array}{l}\text { Gallexie } T \text {. } \\
\text { per } 1,000 \text { hab }\end{array}$ & & & & & & & & $\begin{array}{l}869 \\
17.9 \\
\end{array}$ & & & & $\begin{array}{l}905 \\
19.9 \\
\end{array}$ & & & $\begin{array}{r}1,175 \\
23.4 \\
\end{array}$ & & $\begin{array}{r}1,823 \\
25.9 \\
\end{array}$ & $\begin{array}{r}1,382 \\
26.0 \\
\end{array}$ & & & & $\begin{array}{l}1,706 \\
32.2\end{array}$ & & $\begin{array}{r}1,926 \\
35.9 \\
\end{array}$ \\
\hline $\begin{array}{l}\text { Monuments } T \text {. } \\
\text { per } 1,000 \text { hab. }\end{array}$ & & & & & & & & $\begin{array}{l}5,090 \\
104.9\end{array}$ & & & & $\begin{array}{l}6453 \\
130.4 \\
\end{array}$ & & & \begin{tabular}{|l|}
8,170 \\
162.4 \\
\end{tabular} & & $\begin{array}{l}8.647 \\
174.1 \\
\end{array}$ & $\begin{array}{l}9,220 \\
178.7 \\
\end{array}$ & & & & $\begin{array}{l}18,178 \\
248.6 \\
\end{array}$ & & $\begin{array}{r}14,331 \\
266.8 \\
\end{array}$ \\
\hline $\begin{array}{l}\text { Total } \\
\text { per i, } 000 \text { hab. }\end{array}$ & & & & & & & & $\begin{array}{l}7,342 \\
151.4\end{array}$ & & & & $\begin{array}{l}8,991 \\
1016\end{array}$ & & & $\begin{array}{r}11,084 \\
220.4\end{array}$ & & $\begin{array}{l}12,827 \\
241.2\end{array}$ & $\begin{array}{l}12761 \\
247.3\end{array}$ & & & & $\begin{array}{l}17,364 \\
127.6\end{array}$ & & $\begin{array}{r}18,714 \\
348.5\end{array}$ \\
\hline
\end{tabular}

Source: Annuarlo statistico Italiano Instituto Centrale di Statistica, Ministero dell'Economia Nazionale, Italy, 1948-1972. 
Appendix B

SIDE-EFFECT DESCRIPTIVE INDICATORS 


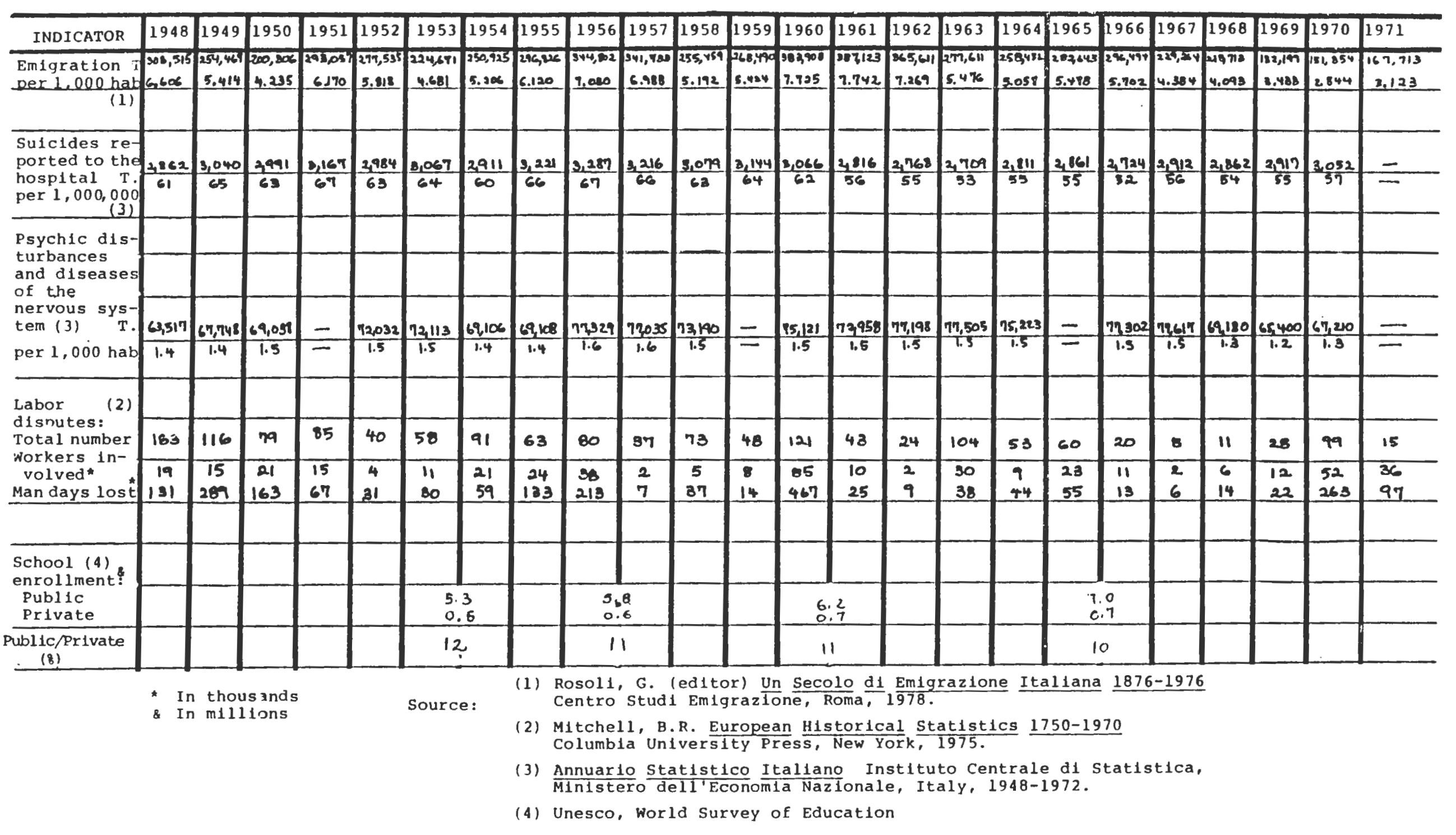


Appendix C

POLICY INSTRUMENT DESCRIPTIVE INDICATORS 
Table C.1 - POLICY INSTRUMENT DESCRIPTIVE INDICATORS:Composition of imports/exports

Appendix C

(percent relative to total)

\begin{tabular}{|c|c|c|c|c|c|c|c|c|c|c|c|c|c|c|c|c|c|c|c|c|c|c|c|c|}
\hline INDICATOR & 1948 & 1949 & 1950 & 1951 & 1952 & 1953 & 1954 & 1955 & 1956 & 1957 & 1958 & 1959 & 1960 & 1961 & 1962 & 1963 & 1964 & 1965 & 1966 & 1967 & 1968 & 1969 & 1970 & 1971 \\
\hline \multicolumn{25}{|l|}{ Imports: } \\
\hline $\begin{array}{l}\text { Food } \\
\text { products }\end{array}$ & & & 22 & 21 & 18 & 19 & 15 & 18 & 18 & 17 & 19 & 19 & & 17 & 17 & 20 & 21 & 24 & & 22 & 21 & 20 & 19 & \\
\hline $\begin{array}{l}\text { Non food } \\
\text { products }\end{array}$ & & & 60 & 50 & 68 & 62 & 65 & 62 & 62 & 62 & 61 & 63 & & 69 & 70 & 67 & 65 & 60 & & 62 & 63 & 66 & 67 & \\
\hline $\begin{array}{l}\text { Auxiliar } \\
\text { material }\end{array}$ & & & 18 & 20 & 19 & 19 & 20 & 20 & 20 & 21 & 20 & 18 & & 14 & 13 & 13 & 14 & 16 & & 16 & 16 & 14 & 14 & \\
\hline \multicolumn{25}{|l|}{ 3xnorts: } \\
\hline $\begin{array}{l}\text { Food } \\
\text { products }\end{array}$ & & & 26 & 20 & 23 & 24 & 25 & 23 & 23 & 24 & 20 & 18 & & 15 & 15 & 14 & 12 & 12 & & 11 & 9 & 9 & 9 & \\
\hline $\begin{array}{r}\text { Non food } \\
\text { products }\end{array}$ & & & 72 & 77 & 70 & 66 & 64 & 60 & 69 & 69 & 72 & 75 & & 79 & 79 & B) & 83 & 83 & & 83 & 85 & 86 & 86 & \\
\hline $\begin{array}{l}\text { Auxiliar } \\
\text { material }\end{array}$ & & & 2 & 3 & 7 & 10 & 11 & 9 & 8 & 7 & 8 & 7 & & 6 & 6 & 5 & 5 & 5 & & 6 & 6 & 5 & 5 & \\
\hline & & & & & & & & & & & & & & & & & & & & & & & & \\
\hline
\end{tabular}

Source: Annuario Statistico Italiano Instituto Centrale di Statistica, Ministero dell'Economia Nazionale,

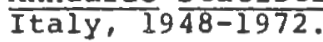


Appendix D

ANALYTIC INDICATORS 


\begin{tabular}{|c|c|c|c|c|c|c|c|c|c|c|c|c|c|c|c|c|c|c|c|c|c|c|c|c|}
\hline INDICATOR & 1948 & 1949 & 1950 & 1951 & 1952 & 1953 & 1954 & 1955 & 1956 & 1957 & 1958 & 1959 & 1960 & 1961 & 1962 & 1963 & 1964 & 1965 & 1966 & 1967 & 1968 & 1969 & 1970 & 1971 \\
\hline $\begin{array}{l}\text { Unemployment } \\
\text { (1) T. }\end{array}$ & 1,742 & 1,673 & 1615 & 1,900 & 1,915 & 1,875 & 1,815 & 1,705 & 1,605 & 1,500 & 1,485 & 1,117 & 836 & 710 & 611 & 504 & 549 & 721 & 769 & 689 & 694 & 665 & 619 & \\
\hline $\begin{array}{r}8 \text { of labor } \\
\text { force }\end{array}$ & 8.9 & 8.6 & 8.3 & 10.1 & 10.0 & 9.7 & 9.3 & 8.7 & 8.2 & 7.6 & 7.5 & 5.6 & 4.2 & 3.5 & 3.1 & 2.5 & 27 & 3.7 & 3.9 & 3.5 & 3.5 & 3.4 & 3.2 & \\
\hline $\begin{array}{l}\text { Employment ( } 1) \\
\text { Agriculture }\end{array}$ & & & & 6,800 & 6,730 & 6,650 & 6,570 & 6,480 & 6,390 & 6300 & 6,250 & 6,006 & 6,020 & 5,600 & 5,494 & 5,295 & 4,967 & 4,956 & 4,647 & 4,556 & 4,249 & 4,027 & 3,669 & \\
\hline & & & & 40.0 & 39.3 & 38.3 & 3r. 3 & 36.4 & 35.5 & 34.6 & 34.0 & 32.1 & 81.3 & 29.5 & 28.8 & 27.0 & 25.4 & $2<1$ & 24.0 & 24.1 & 225 & 21.5 & 19.7 & \\
\hline Industry & & & & 5,505 & 5,619 & 5,768 & 5,926 & 6,059 & 6,180 & 6,320 & 6,380 & 6,920 & 7,201 & 7,466 & 7,629 & 7,986 & 7,996 & 7,928 & 7,601 & 7,782 & 7,887 & $8, p 45$ & 8,207 & \\
\hline 8 & & & & 32.4 & 32.8 & 33.2 & 33.6 & 34.0 & 34.3 & 34.7 & 34.7 & 36.7 & 37.5 & 38.7 & 39.7 & $4 a .7$ & 408 & 40.7 & $40 . b$ & 41.1 & 41.8 & 43.1 & 437 & \\
\hline Other & & & & 4,695 & 4,791 & 4,957 & 5,119 & 5,286 & 5,440 & 5,600 & 5,750 & 5,863 & 6,001 & 6,140 & 6,200 & 6,349 & 6,618 & 6,327 & 6,460 & 6,584 & 6,740 & 6,615 & 6,873 & \\
\hline 8 & & & & 27.6 & 27.9 & 28.5 & 29.1 & 29.6 & 30.2 & 30.7 & 31.3 & 31.2 & 31.2 & 31.8 & 320 & 32.3 & 28.8 & 33.3 & 34.5 & 34.8 & 35.7 & 35.4 & 36.6 & \\
\hline $\begin{array}{l}\text { Total persons } \\
\text { employed (1) }\end{array}$ & & & & $17, \infty$ & 17,140 & $17,3.15$ & 17,615 & 17,825 & 18,10 & $\mid \varepsilon, 2 \in 0$ & 18,340 & KE, ETI & 19,230 & 19,245 & 19,367 & 19,630 & $19,5 \in 1$ & 19,011 & $18,70 t$ & 18,922 & $B, E^{\prime} T 6$ & $18, \in \in 7$ & $18 ; 169$ & \\
\hline $\begin{array}{l}\text { Total labor } \\
\text { force }\end{array}$ & & & & 18900 & 19,055 & 19,250 & 19,430 & $A, 520$ & 19,615 & 19,720 & 19865 & 19,994 & 20066 & 20,005 & 19,978 & 20,134 & 20,130 & 19,732 & 19,497 & 19,611 & 19,570 & 19,352 & 19,388 & \\
\hline $\begin{array}{l}\text { Wages indices } \\
(1955=100)\end{array}$ & & & & & & & & & & & & & & & & & & & & & & & & \\
\hline (2) Agriculture & - & 77 & $7 B$ & 79 & 83 & 92 & 97 & 100 & 105 & 108 & 113 & 115 & 116 & 121 & 133 & 156 & 178 & 195 & 206 & 225 & 237 & 262 & 308 & \\
\hline Industry & 69 & 73 & 76 & 84 & 88 & 90 & 94 & 100 & 105 & 109 & 115 & 117 & 121 & 125 & 135 & 150 & 172 & 186 & 192 & 200 & 207 & 220 & 260 & \\
\hline
\end{tabular}

Source: (1) Stern, R. Foreign Trade and Economic Growth in Italy Praeger Publishers, New York, 1967.

(2) Mitchell, B.R. European Histor1cal Stat1stics 1750-1970 Columbia University Press, New York, 1975. 
Table D. 2 - ANALYTIC INDICATORS (cont.)

Append ix D

\begin{tabular}{|c|c|c|c|c|c|c|c|c|c|c|c|c|c|c|c|c|c|c|c|c|c|c|c|c|}
\hline INDICATOR & 1948 & 1949 & 1950 & 1951 & 1952 & 1953 & 1954 & 1955 & 1956 & 1957 & 1958 & 1959 & 1960 & 1961 & 1962 & 1963 & 1964 & 1965 & 1966 & 1967 & 1968 & 1969 & 1970 & 1971 \\
\hline $\begin{array}{l}\text { Savind deposits } \\
\text { thousands of }\end{array}$ & & & & & & & & & & & & & & & & & & & & & & & & \\
\hline mil & & 4,538 & 1,861 & 2,160 & 2,418 & 29106 & 3,362 & 3,817 & 4,358 & 4,949 & 5,766 & 6,607 & 7,480 & 8,664 & 10,102 & 11,454 & 12,598 & 14,452 & 16,504 & 18,417 & $2 q 430$ & 21,859 & 2,500 & 24,642 \\
\hline 1971 prices & & 3.3 & 1.0 & 4.3 & 4.6 & 5.4 & 6.1 & 6.7 & 7.3 & 8.2 & 9.1 & 10.0 & 12.0 & 13.0 & 14.0 & 15.0 & 16.0 & 17.0 & P.O & 21.0 & 23.0 & 24.0 & 23.0 & 25.0 \\
\hline $\begin{array}{l}\text { Number of } \\
\text { health centers }\end{array}$ & & & & & & & 1,417 & 2,315 & 2,431 & 2,453 & 2,475 & Z,483 & 2,507 & 2,518 & 2,532 & 2563 & 2,553 & 2,518 & 2484 & 3451 & 2,414 & 2390 & 2,318 & 2,285 \\
\hline & & & & & & & 29 & $4 B$ & 50 & 50 & 50 & 50 & 50 & 50 & 50 & 51 & 50 & 49 & $4 B$ & 47 & 46 & 45 & 43 & 43 \\
\hline $\begin{array}{l}\text { Number of } \\
\text { schools: }\end{array}$ & & & & & & & & & & & & & & & & & & & & & & & & \\
\hline $\begin{array}{l}\text { Primary } \\
\text { Secondary }\end{array}$ & & & $\begin{array}{l}39,156 \\
6,122\end{array}$ & $\begin{array}{l}6,138 \\
6,273\end{array}$ & $\begin{array}{l}40,550 \\
6,434\end{array}$ & $\begin{array}{r}41,277 \\
6 R 60\end{array}$ & & & 43,761 & $\begin{array}{l}45,052 \\
7,243\end{array}$ & $\begin{array}{l}45,870 \\
7,418\end{array}$ & $\begin{array}{l}47,170 \\
8,993\end{array}$ & $\begin{array}{l}48,343 \\
2,036\end{array}$ & $\begin{array}{l}44395 \\
9,584\end{array}$ & $\begin{array}{l}47569 \\
9,584\end{array}$ & $\begin{array}{r}45,614 \\
9,523\end{array}$ & $\begin{array}{l}45,034 \\
9,643\end{array}$ & $\begin{array}{l}44,712 \\
9,540 \\
\end{array}$ & & & & & & \\
\hline
\end{tabular}

Source: Annuario Statistico Italiano Instituto Centrale di Statistica, Ministero dell'Economia Nazionale, Italy, 1948-1972. 
Table D. 3 - ANALYTIC INDICATORS (oont.)

Appendix D

\begin{tabular}{|c|c|c|c|c|c|c|c|c|c|c|c|c|c|c|c|c|c|c|c|c|c|c|c|c|}
\hline INDICATOR & 1948 & 1949 & 1950 & 1951 & 1952 & 1953 & 1954 & 1955 & 1956 & 1957 & 1958 & 1959 & 1960 & 1961 & 1962 & 1963 & 1964 & 1965 & 1966 & 1967 & 1968 & 1969 & 1970 & 1971 \\
\hline $\begin{array}{l}\text { Consumption } \\
\text { indices: }\end{array}$ & & & & & & & & & & \multicolumn{2}{|c|}{$1938:-1$} & & & & & & & & & & \multicolumn{3}{|c|}{$k_{1} 70=125$} & \\
\hline Food & & & 65 & 91 & 95 & 97 & 100 & 103 & 107 & 107 & 112 & 108 & 110 & 111 & 117 & 127 & 132 & 139 & & $4: 8$ & $4=8$ & 15.1 & 100,0 & 103.9 \\
\hline Clothing & & & 91 & 111 & 102 & 99 & 100 & 100 & 100 & 102 & 103 & 103 & 105 & 105 & 110 & 117 & 123 & 126 & & 85.1 & $90: 4$ & 93,0 & 100.0 & 107.3 \\
\hline Energy & & & $B 5$ & 92. & 99 & 100 & 100 & 100 & 102 & 104 & 102 & 101 & 101 & 101 & 102 & 106 & 110 & 112 & & 94.4 & 93.9 & 93.9 & 1000 & 104.0 \\
\hline Housing & & & 35 & 59 & 75 & 82 & 88 & 100 & 129 & 154 & 188 & 228 & 263 & 299 & 335 & 380 & 395 & 410 & & 86.0 & 90.1 & 94.8 & 100.0 & 102.9 \\
\hline Other serv. & & & 80 & 91 & 95 & 90 & 98 & 100 & 102 & 106 & 107 & 110 & 114 & 118 & 123 & 134 & 139 & 146 & & 91.1 & 92.8 & 95.1 & 100.0 & 106.5 \\
\hline General & & & 81 & 89 & 93 & 95 & 97 & 100 & 105 & 107 & 112 & 112 & 115 & 118 & 125 & 136 & 141 & 147 & & 91.4 & 92.6 & 95.2 & 100.0 & 105.0 \\
\hline & & & & & & & & & & & & & & & & & & & & & & & & \\
\hline
\end{tabular}

Source: Annuario Statistico Italiano Instituto Centrale di Statistica, Ministero dell'Economia Nazionale, Italy, 1948-1972. 